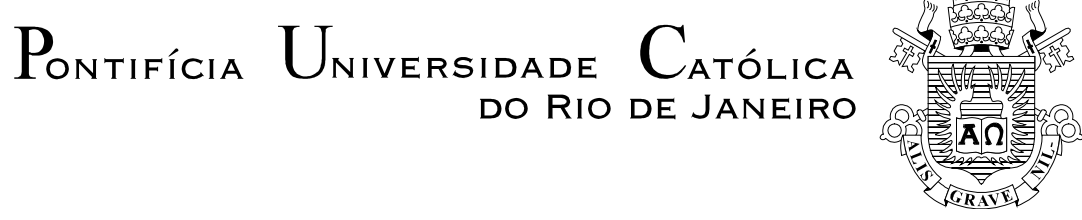

Aluysio Augusto de Athayde Neno

Ordem e Significado - A busca pela ordem nas obras de Eric Voegelin e Claude LéviStrauss

Dissertação de Mestrado

Dissertação apresentada ao Programa de Pósgraduação em Ciências Sociais da PUC-Rio como requisito parcial para a obtenção do título de Mestre em Ciências Sociais.

Orientador: Prof. Valter Sinder

Rio de Janeiro

Setembro de 2013 


$$
\text { Pontifícia } \underbrace{}_{\text {niversidade }} \text { Católica }_{\text {Do Rio de Janeiro }}
$$

Aluysio Augusto de Athayde Neno

\section{Ordem e significado - A busca pela ordem nas obras de Eric Voegelin e Claude Lévi-Strauss}

Dissertação apresentada como requisito parcial para obtenção do grau de Mestre pelo Programa de Pós-Graduação em Ciências Sociais do Departamento de Ciências Sociais do Centro de Ciências Sociais da PUC-Rio. Aprovada pela Comissão Examinadora abaixo assinada.

Prof. Valter Sinder Orientador

Departamento de Ciências Sociais - PUC-Rio

Prof. Ronaldo Oliveira de Castro

UERJ

Prof. Paulo Jorge da Silva Ribeiro Departamento de Ciências Sociais - PUC-Rio

Profa. Mônica Herz Coordenadora Setorial do Centro de Ciências Sociais - PUC-Rio 
Todos os direitos reservados. É proibida a reprodução total ou parcial do trabalho sem autorização da universidade, do autor e do orientador.

\section{Aluysio Augusto de Athayde Neno}

Graduou-se em Ciências Sociais pela PUC-Rio (Pontifícia Universidade Católica do Rio de Janeiro). Pesquisador nas áreas de Antropologia da religião e da arte. Atualmente pesquisa as relações entre religião e política, modernidade e desencantamento, ordem e significado.

Ficha catalográfica

Neno, Aluysio Augusto de Athayde

Ordem e significado: a busca pela ordem nas obras de Eric Voegelin e Claude LéviStrauss / Aluysio Augusto de Athayde Neno ; orientador: Valter Sinder. - 2013.

100 f. ; $30 \mathrm{~cm}$

Dissertação (mestrado)-Pontifícia Universidade Católica do Rio de Janeiro, Departamento de Ciências Sociais, 2013.

Inclui bibliografia

1. Ciências Sociais - Teses. 2. Ordem. 3. Significado. 4. Eric Voegelin. 5. Claude LéviStrauss. 6. Mitologia. 7. Cosmos. 8. Sociedades tradicionais. 9. Sociedades primitivas. 10. Religião. I. Sinder, Valter II. Pontifícia Universidade Católica do Rio de Janeiro. Departamento de Ciências Sociais. III. Título. 
Para meus pais, Aluysio e Virgínia,

Pelo amor e confiança. 


\section{Agradecimentos}

Inicialmente gostaria de agradecer ao corpo docente e aos funcionários do Departamento de Ciências Sociais da PUC-Rio. Em especial, agradeço a Diretora Maria Sarah da Silva Telles pela atenção e apoio ao longo do Mestrado. Não poderia deixa de agradecer a querida Ana Roxo que, em momentos difíceis, sempre se mostrou pronta a ajudar. Também não deixo de citar, aqui, a secretária Monica Gomes a quem sou muito grato.

Ao $\mathrm{CNPq}$ e à PUC-Rio, pelos auxílios concedidos, sem os quais este trabalho não poderia ter sido realizado.

Uma palavra para o meu orientador, o Prof. Valter Sinder, a quem sou muitíssimo grato por toda a paciência, compreensão e ajuda. Minha admiração que, desde os tempos da Graduação já era grande, só se tornou maior. Valter é um grande modelo para mim de professor, antropólogo e pessoa.

Agradeço ainda ao professor Paulo Jorge da Silva Ribeiro pelo interesse em participar da banca desta dissertação. Sua aula de Metodologia das Ciências Sociais, em 2005, ainda na graduação, foi meu primeiro contato com a área a que hoje me dedico. Suas aulas ainda estão na memória, principalmente quando me lembro que, ao chegar em casa, eu debatia com meus familiares sobre todas as importantes "desconstruções" empreendidas por nossas leituras e discussões.

Quero agradecer ainda ao professor Ronaldo Oliveira de Castro, a quem convidei para fazer parte da banca. Vindo de outra instituição, a UERJ, agradeço ao professor pelo interesse e pelos importantes comentários dados na Qualificação.

Ao querido amigo e companheiro nesta viagem, Guilherme Neves Gonçalves, agradeço pelos momentos em que compartilhamos nossas angústias e nossas alegrias. Com um olhar que pulsa vida, Guilherme provou ainda haver vida inteligente neste mundo.

Ao amigo Pedro Augusto Salarini, porque simplesmente não há como não agradecer a um irmão. Nossas vidas estão tão entrelaçadas, que tudo o que faço é 
compartilhado, discutido entre nós. Foram muitas palavras generosas em todos essas anos, das quais tento retribuir com toda a minha gratidão.

Outro grande amigo que não posso deixar de citar é Ivan Frota Pacheco. A ele toda a minha gratidão pela lealdade da amizade, pelas longas conversas e por ter sido o primeiro a me mostrar um outro lado na vida intelectual.

À Juliana Zurli Monteiro, pelo companheirismo, compreensão e amor. Não tenho dúvidas de que essa dissertação carrega muito de nós dois.

A toda a minha família (tios, tias, primos e primas), que muito amo. Especialmente às minhas tias Wanda de Azevedo Athayde e Leína Athayde Dutra, que sempre se desdobraram para me ajudar. À Denize Athayde Dutra pelo apoio, carinho e amor sem medidas. E à Ana Beatriz, minha irmã, pelas palavras doces e generosas de compreensão e apoio.

Por fim, agradeço aos meus amados pais, Aluysio e Virgínia, a quem dedico esta dissertação. Todos estes anos, em todos os momentos, sempre pude contar com muito carinho e amor. Sei que jamais conseguiria morar longe e ter obtido tantas conquistas sem o apoio deles. Sem eles, nada do que faço teria sentido... 


\section{Resumo}

Neno, Aluysio Augusto de Athayde; Sinder, Valter. Ordem e Significado - a busca pela ordem nas obras de Eric Voegelin e Claude LéviStrauss. Rio de Janeiro, 2013. 100p. Dissertação de Mestrado Departamento de Ciências Sociais, Pontifícia Universidade Católica do Rio de Janeiro.

Uma das temáticas mais fascinantes e recorrentes nas Ciências Sociais e, mais especificamente na Antropologia, é a problemática da ordem. Essa dissertação foca a sua análise em como os homens empreendem a imprescindível tarefa de dar significado às suas vidas, às suas instituições, às suas sociedades. Ordenar, nesse contexto, nada mais é do que dar uma justificação, um fundamento à todas as coisas que compõem a vida humana. Assim, parto da ideia de que a maneira mais eficaz de dar ordem e significado (seja a vida individual ou a sociedade e suas instituições) se encontra na religião. Admito, porém, que as estruturas de significado presentes nas diferentes culturas não possuem a firmeza necessária para se impor a todos com a mesma intensidade e da mesma forma. Portanto, para evitar que o mundo social perca a sua eficácia, é necessário nomizar ou ordenar a sociedade de uma forma estável e duradoura. A religião, admitida aqui como a forma mais eficaz de dar ordem ao meio social, aparecerá no contexto do que o filósofo Eric Voegelin chamou de "sociedades cosmológicas", ou nas chamadas "sociedades frias" como denominou o antropólogo Claude Lévi-Strauss. A ordem e a construção dos significados nas diferentes sociedades serão analisadas através das obras desses dois autores.

\section{Palavras-Chave}

Ordem; Significado; Eric Voegelin; Claude Lévi-Strauss; Mitologia; Cosmos; Sociedades tradicionais; Sociedades primitivas; Religião. 


\section{Abstract}

Neno, Aluysio Augusto de Athayde; Sinder, Valter (Advisor). Order and Meaning - the search of order in the works of de Eric Voegelin and Claude Lévi-Strauss. Rio de Janeiro, 2013. 100p. MSc. Dissertation Departamento de Ciências Sociais, Pontifícia Universidade Católica do Rio de Janeiro.

One of the most fascinating and recurring themes in Social Sciences and, more specifically, in Anthropology, is the problem of order. This dissertation focuses its analysis on how men undertake the essential task of giving meaning to their lives, their institutions and societies. To order, in this context, is nothing more than to give a justification, a ground for all things that make up human life. Thus, I take off from the idea that the most effective way of ordaining and establishing meaning (whether to individual life or society and its institutions) lies in religion. I admit, however, that the structures of meaning present in different cultures do not have the necessary firmness to enforce all with the same intensity and in the same manner. Therefore, to prevent the social world from losing its effectiveness, it is necessary to normalize or order society in a stable and lasting way. Religion, admitted as the most effective way to provide order to social life, appears in the context of what the philosopher Eric Voegelin called "cosmological societies.", or "cold societies" as Claude Lévi-Strauss called in his works. The order and the construction of meanings in the different societies will be analysed through the works of this two authors.

\section{Keywords}

Order; Meaning; Eric Voegelin; Claude Lévi-Strauss; Mythology; Cosmos; Traditional societies; Primitive societies; Religion. 


\section{Sumário}

1. Introdução

2. Ordem e simbolização

21

2.1 O problema da ordem nas Ciências Sociais 21

2.2 O sagrado e a ordem 32

2.3 Legitimação e sociedades cosmológicas 35

3. Eric Voegelin e a busca da ordem 42

3.1 Combatendo o bom combate 42

3.2 A história das ordens $\quad 45$

3.3 A simbolização compacta e as sociedades cosmológicas $\quad 49$

3.4 A mitologia e a condição humana 52

3.5 Cosmos e ordem: a simbolização política 57

3.6 A estrutura da realidade, a consciência e a busca da ordem 61

4. Lévi-Strauss: a forma e o significado 69

4.1 O antropólogo contra a corrente 69

4.2 A busca pelo universal 72

4.3 "A etnologia é, primeiro, uma psicologia 73

$\begin{array}{ll}4.4 \text { Mito e significado } & 77\end{array}$

5. Conclusão 87

6. Referências Bibliográficas 98 
"What is permanent in the history of mankind is not the symbols but man himself in search of his humanity and its order."

Eric Voegelin

"Falar de regras e falar de significado é falar da mesma coisa; e, se olharmos para todas as realizações da Humanidade, seguindo os registros disponíveis em todo o mundo, verificaremos que o denominador comum é sempre a introdução de alguma espécie de ordem. Se isto representa uma necessidade básica de ordem na esfera da mente humana e se a mente humana, no fim de contas, não passa de uma parte do universo, então quiçá a necessidade exista porque há algum tipo de ordem no universo e o universo não é um caos."

Claude Lévi-Strauss 


\section{1.}

\section{Introdução}

O problema da ordem talvez seja questão fundamental da sociedade humana. Peter Berger inicia seu livro "O dossel sagrado" com a seguinte frase: "Toda sociedade humana é um empreendimento de construção do mundo" (BERGER, 2012: 15). Eric Voegelin, no primeiro volume de Ordem e História, "Israel e a Revelação", inicia sua obra com a seguinte passagem: “A ordem da história surge da história da ordem. Toda a sociedade vê-se encarregada da tarefa de, sob suas condições concretas, criar uma ordem que dote de significado o fato de sua existência em termos dos fins divinos e humanos" (VOEGELIN, 2009: 27). Dotar de significado a existência no plano macro (sociedade) e no plano micro (indivíduo), eis aí a grande tarefa humana. Tarefa essa, que sempre procurei estudar, pois exerce em mim um grande fascínio. Quando me deparei com uma bibliografia que se propunha a debater essa questão, tive a certeza de que as Ciências Sociais (logicamente, unida com outras áreas do conhecimento) haviam sido a escolha certa. Recordo-me, ainda, que o primeiro livro da área que peguei para ler foi o clássico A construção social da realidade de Peter Berger e Thomas Luckmann, que, evidentemente, trabalha com a questão da significação e da ordem nas sociedades. Além, é claro, de outras grandes obras como As formas elementares da vida religiosa do founding father Émile Durkheim, os artigos de Mauss (e a clássica Introdução de Lévi-Strauss) em Sociologia e Antropologia, a sociologia da religião de Max Weber, as obras de Claude Lévi-Strauss, os tratados de religião comparada de Mircea Eliade, sem esquecer ainda do magnífico The golden bogh de Sir James Frazer. Mais recentemente me deparei com a grandiosa coletânea Ordem e História do filósofo e cientista político Eric Voegelin, que, pelo próprio nome da obra, trata exaustivamente do problema da ordem nas diferentes sociedades e tempos históricos. 
Nesse trabalho, a despeito da enorme bibliografia sobre o tema, me deterei, sem menosprezar em absoluto os outros autores, com as obras de Eric Voegelin e Lévi-Strauss.

Sabemos que as Ciências Sociais talvez sejam um das áreas que mais produziu obras sobre a temática religiosa. O fascínio por mitos, ritos, símbolos, anjos e demônios, magia e alquimia, mestres e iniciações, que os cientistas sociais possuem é impressionante. Ao mesmo tempo, também sabemos que as Ciências Sociais, desde seu nascimento, sempre se distanciou da metafísica. Weber, no início da seção consagrada à Sociologia da Religião, em seu clássico Economia e Sociedade, afirma que esta disciplina não trata da religião como tal, e sim das suas relações com a vida social. Antes do próprio Weber, outros, como Comte e Durkheim, já haviam afirmado a mesma coisa.

Peter Berger, o famoso sociólogo americano, apesar de ser pessoalmente religioso, produz uma sociologia da religião que também não escapa a esse tipo de análise. Citando a passagem de Berger em sua grande obra $O$ dossel sagrado:

“[...]A religião é definida aqui como um empreendimento humano porque é assim que ela se manifesta como fenômeno empírico. No âmbito dessa definição, a questão de se saber se a religião pode também ser algo mais que isso é omitida como, é claro, deve-se fazer em qualquer tentativa de compreensão científica." (BERGER, 2012, p. 38)

Assim, centrando a análise no que Voegelin chamou de "sociedades cosmológicas" (sociedades arcaicas ou "primitivas"), pretendo demonstrar a maneira pela qual essas sociedades empreendem a tarefa humana de dar uma ordem à sociedade, de construir significados, classificações, de retirar as coisas do fluxo contínuo do "caos" e "cosmificá-las". E nesse tipo de organização social, a ordenação e a religião são uma só e mesma coisa. O "caos" torna-se "cosmos" através de "justificativas" religiosas, ou, falando de uma outra forma, nessas sociedades a ordem é fruto do sagrado. O "sagrado" (se opondo ao profano, como na análise clássica de Mircea Eliade) tem o poder de "cosmificar" (sensu Eliade) a realidade social de uma maneira muito forte. Desta forma, quando o mundo social é encarado como "coisa óbvia", quando a ordem parece provir da natureza mesma das coisas, há uma fusão do nomos (a ordem socialmente estabelecida) com o 
cosmos (tudo aquilo que é considerado como os sentidos fundamentais inerentes ao universo). Nesse momento a socialização obtém grande êxito, na medida em que os programas institucionais passam a ter um caráter ontológico a tal ponto que, como diz Berger, negá-los equivaleria a negar o próprio ser: o ser da ordem universal das coisas e, como conseqüência, o que se é nessa mesma ordem.

Nas sociedades arcaicas (ou "cosmológicas"), a ordem social (nomos) é o reflexo microcósmico do cosmos como tal, sendo esse cosmos compreendido como coisa sagrada. Voegelin chega a dizer que ela não é vista apenas como um reflexo, uma expressão dos significados inerentes ao universo como tal, mas essa ordem chega a ser encarada como o cosmos mesmo. Esse tipo de ordenação é encontrado nas mais variadas sociedades, existindo uma espécie de uniformização, logicamente com características específicas em cada fenômeno. É sabido, portanto, que existem uniformidades entre os fenômenos "sagrados" ou "religiosos" de diferentes culturas. Sobre esse caso, vale citar Berger:

\footnotetext{
"As manifestações históricas do sagrado variam muito, embora transversalmente se observem uniformidades na cultura (pouco importando, aqui, que essas uniformidades se devam interpretar como resultantes da difusão cultural ou de uma lógica interna da imaginação religiosa do homem).”(BERGER, 2012, p. 39)
}

Berger, como a maioria dos sociólogos e antropólogos, não quer colocar em questão como pode ser explicada essa uniformidade que encontramos na temática religiosa (e em outras temáticas) entre os mais diferentes grupos sociais. Aqui, entra um ponto muito importante dessa dissertação.

Como dito acima, sempre me fascinei pela questão da ordem, procurando sempre descobrir como os diferentes autores explicavam (ou não) os mecanismos de significação e ordenação das coisas numa dada sociedade. Assim, pretendo aqui, também, esboçar algumas teorias que tentam explicar essa temática e acho que, abstraindo apenas por um momento os diferentes grupos sociais, podemos fazer uma pergunta fundamental: a ordem é produzida de forma arbitrária ou ela é fruto de uma lógica? Se a ordem é arbitrária, como podemos explicar esse fenômeno da universalidade de algumas características da cultura? Se a ordem é fruto de alguma lógica, da onde provém essa lógica?

No fundo, sabemos que essa questão perpassa todo o debate da Antropologia, pois, ao afirmar a supremacia da cultura sobre a natureza, e fazer do 
homem uma tábula rasa, nossa área acabou por se distanciar de outros debates na psicologia, na ciência cognitiva, na neurociência, na filosofia e na metafísica. Não pretendo, aqui, defender esse "outro lado", mas apenas fazer uma pequena problematização das relações entre a "construção social", a natureza e a metafísica. Acredito que sob uma perspectiva de contraste podemos compreender melhor o que se passa (e se passou) na Antropologia e nas Ciências Sócias em geral.

Não quero, de forma alguma, soar prepotente, pois sei que esse assunto já foi e será ainda tema de muitos debates nas mais variadas áreas do conhecimento. Por isso, me propus a trabalhar com uma bibliografia mais clássica sobre o tema, que problematiza como se dá essa construção social, como é feita a ordem e as significações. Logicamente, como esse é um tema que perpassa um escopo enorme, me limitarei, como dito acima, a analisar aqui apenas a obra do filósofo e cientista político alemão Eric Voegelin sobre as "sociedades cosmológicas" (ou sociedades arcaicas, "primitivas") e as maneiras como essas sociedades empreendem a tarefa de dar ordem ao meio social, e as idéias de Claude LéviStrauss a respeito de como os "povos sem escrita" empreendem a tarefa de significar, ordenar e simbolizar suas ordens.

Ainda assim, na temática da ordem, não posso deixar de citar aqui algumas pequenas passagens, dos autores citados, que muito me impressionaram (e impressionam) e que me estimularam a realizar esse trabalho. Lévi-Strauss, a que muitos têm como o maior pensador dentro da Antropologia, foi um dos poucos que tentou resolver a questão da "reincidência das ordens". Cito-o, aqui, em seu Mito e Significado:

"Falar de regras e falar de significado é falar da mesma coisa; e, se olharmos para todas as realizações da Humanidade, seguindo os registros disponíveis em todo o mundo, verificaremos que o denominador comum é sempre a introdução de alguma espécie de ordem. Se isto representa uma necessidade básica de ordem na esfera da mente humana e se a mente humana, no fim de contas, não passa de uma parte do universo, então quiçá a necessidade exista porque há algum tipo de ordem no universo e o universo não é um caos" (LÉVI-STRAUSS, 1985, p. 24).

Lévi-Strauss, que marcou o universo da Antropologia e, mais do que isso, o mundo das Ciências Humanas, com seu estruturalismo, permite compreender as similitudes das diferentes ordens através de um materialismo hard. Partindo, aqui, da posição de um de seus "herdeiros", o antropólogo Philippe Descola, podemos 
dizer, que recusando a oposição entre matéria e espírito, Lévi-Strauss afirmou que toda a vida social é marcada por dois determinismos simultâneos e complementares:

“[...] um, de tipo tecnoeconômico, impõe ao pensamento coerções resultantes da relação que a sociedade mantém com um meio particular; o outro reflete as exigências inerentes ao funcionamento do espírito e se manifesta sempre idêntico, independentemente das diferenças entre os meios.” (DESCOLA, 2011, p. 37)

Esse primeiro determinismo nos lembra que o etnólogo, como tão bem fez Lévi-Strauss, deve conhecer as propriedades objetivas dos objetos naturais, que o espírito vai selecionar em determinado contexto cultural para encaixá-lo em conjuntos significantes, como os mitos e as taxonomias. Assim, para o antropólogo, é importante conhecer bem a ecologia de uma sociedade se há a intenção de analisar suas produções ideológicas, pois elas são a prova de um compromisso entre certos traços do meio e as leis que organizam o pensamento simbólico.

Essa natureza enciclopédica, a que o pensamento se apropria para suas simbolizações, é "boa para pensar". Mas, essa natureza que está à disposição do espírito humano se opõe àquela outra a que Lévi-Strauss sempre evoca: a natureza orgânica da nossa espécie. É por meio dessa natureza que, segundo Lévi-Strauss, efetuamos a percepção e a intelecção dos objetos sensíveis, ela é o mecanismo biológico que garante a unidade das operações mentais e "autoriza a esperança de decifrar-lhes as regras" (DESCOLA, 2011, p. 38). Enquanto a natureza externa é colocada num papel subsidiário, a natureza corporal é vista pelo antropólogo num lugar privilegiado. Como na passagem citada de Mito e Significado, a teoria das faculdades lévi-straussiana se recusa a separar os estados da subjetividade, das propriedades do cosmos. Assim, como diz o antropólogo:

"[...] as leis do pensamento são as mesmas que se exprimem na realidade física e na realidade social, não sendo esta última outra coisa que um dos seus aspectos" (LÉVI-STRAUSS, 1982, p. 520).

Portanto, há uma base da natureza a que o indivíduo se utiliza nas suas construções simbólicas, mas essas construções obedecem às leis do pensamento que são as mesmas que se exprimem na realidade física e social. 
Em $O$ pensamento selvagem, porém, Lévi-Strauss ressalta o aspecto arbitrário que comanda as escolhas dos traços distintivos atribuídos a tal ou qual componente dos ecossistemas locais. Nas palavras de Descola:

“[...]Lévi-Strauss insistia em mostrar que não há nada de automático nem de previsível no modo como uma sociedade seleciona este ou aquele aspecto de seu hábitat para atribuir-lhe um significado particular e integrá-lo em suas construções míticas.” (DESCOLA, 2011: 38)

Essa arbitrariedade, no entanto, segundo Lévi-Strauss, é compensada pela organização dos elementos em sistemas coerentes. A estrutura dos mitos, portanto, não é aleatória, mas se organiza dentro de determinado número de regras. Assim, exponho, por enquanto, um pouco das explicações do antropólogo sobre o tema, já que o assunto será tratado de forma pormenorizada adiante.

Outro pensador que aqui evoco, como dito acima, é Erich Hermann Wilhelm Vögelin (1901-1986), ou Eric Voegelin. Reconhecido internacionalmente, Voegelin figura como um dos maiores pensadores do século $\mathrm{XX}$, tendo travado discussões com inúmeros intelectuais como, por exemplo, Hans Kelsen e Hannah Arendt, e dono de uma vasta obra (sua obra completa possui 34 volumes) que influenciou e influencia muitos intelectuais.

No Brasil, Voegelin foi deixado no ostracismo, mesmo que em 1979 a Universidade de Brasília tenha lançado o seu A nova ciência da política. Com sua enorme erudição e seu não-flerte com questões mais à esquerda, Voegelin sempre teceu críticas ao pensamento revolucionário, mas críticas de ordem filosófica, que impediam qualquer tentativa maniqueísta de analisar a questão como um conflito entre um "liberal" (no sentido brasileiro do termo) e seus pensamentos contra os "progressistas". Muito pelo contrário, o filósofo sempre deixou claro que a honestidade intelectual depende ipso facto do afastamento de qualquer ideologia e, conseqüientemente, de não enquadrar o mundo em categorias estanques e opostas: "Até hoje sustento que não se pode, em hipótese alguma, ser ao mesmo tempo um ideólogo e um cientista social competente." (VOEGELIN, 2008, p. 80)

Assim, em 1979, num Brasil dominado, nas ciências sociais, pelo pensamento marxista, Voegelin não vingou nas "classes pensantes" nacionais. Ao contrário, a intelectualidade brasilis se fez de ouvidos moucos para tentar fazer um reacionário, como este, sumir das estantes. Ledo engano, pois que grande parte da intelectualidade mundial lia e discutia Voegelin (mesmo não 
concordando com seu pensamento), enquanto o Brasil submergia nas suas escolhas intelectuais, sempre com um ar (mentiroso) de avant la lettre. Hoje, porém, temos publicadas, por editoras brasileiras, várias obras de Voegelin, como toda a coletânea de Ordem e História e mais alguns livros como Hitler e os alemães (que lhe rendeu o exílio nos Estados Unidos) e Reflexões Autobiográficas, além de livros de comentadores e estudiosos da obra do filósofo.

Nessa dissertação, Voegelin entrará com sua análise sobre o que denominou "sociedades cosmológicas". Muito citado por Peter Berger em inúmeros de seus livros, Voegelin se propôs a estudar a "história das ordens" em seu Ordem e História. Definindo "ordem" como "a estrutura da realidade como experienciada pelo homem, bem como a sintonia do homem com uma ordem não fabricada por ele, isto é, a ordem cósmica" (VOEGELIN, 2008, p. 117), Voegelin em Israel e a Reveleção, o primeiro volume de Ordem e História, analisa as simbolizações da "ordem cosmológica do antigo Oriente Próximo" (Mesopotâmia, o império aquemênida, e o Egito) e das simbolizações de ordem em Israel. Seu procedimento ao analisar as diferentes sociedades pode ser observado na seguinte passagem:

\begin{abstract}
"Uma vez que o homem não espera pela ciência até que ela lhe explique a própria vida, quando o teórico aborda a realidade social encontra um campo já ocupado pelo que poderia ser chamado de auto-interpretação da sociedade. A sociedade humana não é simplesmente um fato ou uma ocorrência do mundo exterior, que o observador devesse estudar como se fosse um fenômeno natural. Embora a exterioridade seja um de seus componentes importantes, ela é em seu todo um pequeno mundo, um cosmion, cujo significado provém do seu próprio interior, através de seres humanos que continuamente o criam e recriam, como modo e condição de sua auto-realização.” (VOEGELIN, 1979, p. 32)
\end{abstract}

Esse tipo de abordagem se relaciona profundamente com a metodologia antropológica ${ }^{1}$. Voegelin nos lembra que as simbolizações usadas na realidade social, nesse cosmion, não podem ser encaradas como conceitos teóricos, para que não haja risco de uma "transferência" dos conceitos do estudioso para a realidade social estudada. Assim, ao observar as sociedades cosmológicas, Voegelin procura não fazer tabula rasa desses grupos, como se pudesse inscrever seus

\footnotetext{
${ }^{1}$ Voegelin, no caso, tenta usar essa metodologia na Ciência Política, no seu livro A nova ciência da política, um resumo da conferência por ele proferida em 1952. Foi publicado, lá fora, pela Universidade de Chicago e, aqui, pela UnB. No fundo, é um tratado contra o positivismo ainda reinante, na época, nas Ciências Sociais.
} 
conceitos, mas começa a analisá-los a partir do rico conjunto de autointerpretações e prossegue através do esclarecimento crítico dos símbolos sociais preexistentes.

Desta maneira, a ordem das sociedades cosmológicas é simbolizada analogicamente a partir de uma ordem concebida do cosmos. Assim, os ritmos da vida vegetal e animal, o ciclo das estações, as revoluções do sol, da lua e das constelações podem servir de modelos para a simbolização analógica da ordem social. Na lógica de Lévi-Strauss, essa seria a natureza enciclopédica à serviço das criações e simbolizações do espírito humano.

Para Voegelin, se há uma "história da ordem" e as ordens possuem características comuns, isso se deve às "experiências de equivalência". Segundo Voegelin, esse conceito foi tirado das análises finais de Aristóteles. O estagirita, segundo Voegelin, ao longo da vida, foi ficando cada vez mais fascinado pelo mito como fonte de sabedoria, fonte essa mais abrangente do que as estruturas da realidade diferenciadas pelo filósofo. Segundo Voegelin, Aristóteles compreendeu as relações existentes entre experiências e simbolizações nos vários níveis de compactação e diferenciação. A simbolização compacta, para Voegelin, refere-se a das sociedades cosmológicas. A diferenciação é o processo (sem um fim último, pois o filósofo não acredita em um eidos ou sentido da história), que através do "saltos no ser", faz surgir simbolizações mais complexas como as de Israel e da Grécia. Portanto, o filósofo diz que "[o] conceito de equivalência expressa a identidade reconhecível da realidade, experienciada e simbolizada em diversos níveis de diferenciação" (VOEGELIN, 2008, p. 160). Em outras palavras, apesar das diferentes ordens, a reincidência de características das mesmas pode ser explicada, segundo Voegelin, pelo conceito de "experiência de equivalência", pois as diferentes sociedades experienciam a mesma realidade, e essa realidade é autoevidente:

\footnotetext{
"Precisei desistir de tomar 'as idéias' por objetos de uma história e definir que o fenômeno investigado seria a experiência da realidade - pessoal , social, histórica, cósmica. No entanto, só era possível explorar essas experiências investigando suas articulações por meio de símbolos. A delimitação do tema e , com ela, do método a ser utilizado nessa investigação fez-me chegar ao princípio básico de toda a minha obra mais tardia: a realidade da experiência é autoevidente. Os homens valem-se de símbolos para expressar suas experiências, e os símbolos são a chave para compreender essas experiências. Não há o menor sentido em supor, por exemplo, que os sacerdotes egípcios que escreveram a
} 
Teologia de Mênfis ou os sacerdotes mesopotâmicos que desenvolveram o Livro dos Reis da Suméria fossem incapazes de articular experiências de forma clara por terem problemas diferentes dos de um Voiltaire, um Comte ou um Hegel. O que é experienciado e simbolizado como realidade, em um processo de progressiva diferenciação, é a substância da história." (VOEGELIN, 2008, p. 124 - grifos do autor)

Portanto, para o filósofo, todas as sociedades experienciam a mesma substância da história, e a articulam e simbolizam de diferentes maneiras, mas essas diferentes formas de simbolização possuem características semelhantes. Ao longo desse trabalho, iremos ver como Voegelin analisou as simbolizações da ordem através de três características básicas: a predominância da comunidade do ser; a transitoriedade dos parceiros na comunidade do ser; e a tentativa de tornar a ordem essencialmente incognoscível do ser o mais inteligível possível por meio da criação de símbolos que interpretem o desconhecido por analogia com o realmente, ou supostamente, conhecido.

Ao misturar Lévi-Strauss e Eric Voegelin para a discussão do problema da ordem, posso ser acusado de unir análises muito distantes. Porém, o que procurarei fazer aqui é mostrar como elas possuem semelhanças grandes, também admitindo suas diferenças e impossibilidades de intercomunicação. No fundo, existe uma união de análise entre, respectivamente, um antropólogo e um cientista político/filósofo. Essa junção permite olhar para a problemática da ordem por ângulos diferentes e só faz enriquecer esse debate.

É preciso lembrar, também, do importante artigo de Jeffrey C. Alexander, "O novo movimento teórico", que coloca as diferentes teorias em uma perspectiva histórica. Assim, diz o autor:

"Contra a dominação do funcionalismo no pós-guerra empreenderam-se duas revoluções. Por um lado, surgiram escolas radicais e estimulantes de microteorização, acentuando o caráter contingente da ordem social e a centralidade da negociação individual. Por outro lado, desenvolveram-se vigorosas escolas de macroteorização, enfatizando o papel de estruturas coercitivas na determinação do comportamento individual e coletivo." (ALEXANDER, 1986, p. 1)

Pode-se dizer que os trabalhos de Voegelin e de Lévi-Strauss vão no sentido do que Alexander chama de "macroteorização". Ambos intelectuais fizeram um enorme esforço para compreender "universais", reincidências, equivalências, estruturas, formas do consciente e do inconsciente humano. 
É possível ainda dizer que ambos os pensadores colocaram problemas inovadores na área das Ciências Sociais e mais propriamente no estudo da ordem. Esse trabalho, portanto, pretende ser uma pequena contribuição para as análises sobre a ordem. 
2.

\section{Ordem e simbolização}

\section{1}

\section{O problema da ordem nas Ciências Sociais}

O "problema da ordem", assim caracterizado por Jeffrey Alexander, dentro das Ciências Sociais perpassa a ideia de como a sociedade e o indivíduo empreendem a tarefa de dar um significado e uma ordem para o seu mundo social. As instituições, os valores, as crenças, o poder, e tudo aquilo que permeia o meio social, necessitam de ordenação e significação. A "construção social realidade", nome homônio do livro de Peter Berger, é a construção de um nomos ou de uma ordem significativa, a função mais importante da sociedade. Ao ordenar a sociedade de maneira significativa, não só mundo social passa a fazer sentido, como a vida do indivíduo torna-se compreensível diante do mundo. Sobre a questão da ordem dentro de nossa disciplina, diz Alexander:

\footnotetext{
"Refiro-me ao famoso 'problema da ordem', embora o defina de maneira ligeiramente diferente do que tem sido tipicamente o caso. Os sociólogos são sociólogos porque acreditam que a sociedade têm padrões, estruturas de alguma maneira diferentes dos atores que a compõem. Concordando embora com a existência de tais padrões, os sociólogos estão freqüentemente em desacordo sobre como na realidade a ordem é produzida. Uma vez mais formularei esses desacordos em termos de tipos ideais dicotômicos, porque é exatamente esse desacordo cumulativo que caracteriza a história empírica e discursiva do pensamento social (Ekeh, 1974 e Lewis e Smith, 1980). Essa dicotomia opõe as posições individualista e coletivista. (ALEXANDER, 1986, p. 9)
}

Tento, nesse primeiro capítulo, tratar do problema da ordem através do instrumental das Ciências Sociais. Privilegio na análise as posições tomadas por Peter Berger, em seus livros O Dossel Sagrado e A construção social da realidade, que me parece fazer uma síntese bem construída das abordagens 
sociológicas, entre outras, de Weber e Durkheim. Síntese que procura não perder as intenções fundamentais dos founding fathers da sociologia, tentando, portanto, equilibrar as posições individualista e coletivista a que Alexander se refere no trecho acima.

Além disso, foi através de Berger que, inicialmente, tomei conhecimento do problema da ordem e de, como veremos mais à frente, como a religião é o empreendimento de ordenação mais penetrante e duradouro.

Assumo que a sociedade é um fenômeno dialético, no sentido em que ela é um produto humano e, ao mesmo tempo, retroage de maneira contínua sobre o homem, seu produtor. Como na famosa frase de Clifford Geertz - "Acreditando, como Marx Weber, que o homem é um animal amarrado a teias de significados que ele mesmo teceu [...]" (GEERTZ, 1978, p. 39) - acredito que não pode haver realidade social sem a presença de seu produtor, assim como, esse mesmo produtor é um produto da sua sociedade, uma visão endossada por muitos cientistas sociais.

Esse processo dialético é expresso em três momentos da sociedade: a exteriorização, a objetivação e a interiorização. A exteriorização é “[...] a contínua efusão do ser humano sobre o mundo, quer na atividade física quer na atividade mental dos homens" (BERGER, 2012, p. 16). Esse fato é, para Berger (ancorado em uma plêiade de especialistas), uma necessidade antropológica. Nesse sentido, o homem é "inacabado" ao nascer. A estrutura de seus instintos não possui um caráter especializado, como é o caso do animal não-humano, que possui instintos altamente especializados e dirigidos. O mundo do animal não-humano é um conjunto fechado em termos de possibilidades, pois a estrutura de seus instintos determina esse mundo de maneira mais ou menos completa. Não há um mundo do homem, no mesmo sentido em que há um mundo dos cavalos, um mundo dos ratos, dos cães. O mundo do homem é um mundo aberto, possível de ser modelado (alguns dizem, com limites) pela própria atividade humana. Ele existe antes do homem, mas não está pré-fabricado para ele. É a esse homem que compete fazer um mundo para si. No "tornar-se homem" existe, então, um fundamento biológico, pois o "inacabamento" humano compele ao homem a atividade exteriorizante de criar um mundo, desenvolver uma personalidade e assimilar a cultura. Assim, afirma Berger: "O ser humano é exteriorizante por essência e desde o início" (BERGER, 2012, p. 17). 
Estando biologicamente privado de um "mundo do homem", possuindo uma "instabilidade congênita" (BERGER, 2012, p. 18) em relação ao mundo, esse homem precisa pôr-se em equilíbrio no seu habitat. Por não poder "descansar em si mesmo" (Idem) ${ }^{2}$, é necessário que ele forneça à sua vida estruturas firmes, em contrapartida às que lhe faltam biologicamente. Essas estruturas firmes, que iremos ver que não são tão firmes assim, se encontram na cultura.

Adoto aqui um conceito de cultura corrente na antropologia cultural americana para se referir à totalidade de produtos humanos. Como já dito acima, alguns desses produtos são materiais e outros não. Os exemplos mais evidentes desses tipos de produtos são, respectivamente, os utensílios e ferramentas que, em grande parte, promovem uma transformação da natureza pelas mãos dos homens, e a linguagem, que gera uma enorme gama de símbolos que participam profundamente da vida humana.

A sociedade é um elemento da cultura. Portanto, partilha com os outros elementos culturais da propriedade de ser um produto humano. Porém, é preciso lembrar, como faz Eric Voegelin em A nova ciência da política, que embora a exterioridade seja um componente importante no estudo das sociedades, a sociedade é em seu todo, um cosmion, um pequeno mundo, onde os seres humanos continuamente criam e recriam seu significado, como modo e condição de sua auto-realização. Esse cosmion é iluminado por um complexo simbolismo que, como veremos mais à frente com Voegelin, varia em graus de maior ou menor compactação e diferenciação. Esse conjunto de símbolos ilumina com um significado o mistério da existência humana, dando um sentido à estrutura interna desse pequeno mundo, possibilitando um significado das relações entre seus membros e grupos de membros, assim como a existência como um todo. Nas palavras de Voegelin:

\footnotetext{
“A auto-iluminação da sociedade através dos símbolos é parte integrante da realidade social, e pode-se mesmo dizer que é uma parte essencial dela, porque através dessa simbolização os membros da sociedade a vivenciam como algo mais que um acidente ou uma conveniência; vivenciam-na como pertencendo a sua essência humana." (VOEGELIN, 1979, p. 33)
}

A criação do complexo de símbolos é um empreendimento coletivo, bem

\footnotetext{
${ }^{2}$ Como diz Voegelin, ninguém pode "cair em si mesmo" e não descobrir o grande vazio dessa experiência.
} 
como a construção dos bens materiais. O que quer dizer que a "construção humana do mundo é sempre social" (BERGER, 2012, p. 20). Juntos, homens fabricam máquinas e ferramentas, aderem a valores, criam instituições e estabelecem línguas. Através de dispositivos sociais, a cultura, esse apanhado de produtos humanos, mantém sua posição e manutenção. Assim, a sociedade apareceu, aqui, anteriormente como um resultado, ou elemento da cultura. Mas, já se pode ver que ela também é uma condição para a existência da última. O encaixe das peças culturais produzidas pelos homens é feito através de uma mediadora que é a sociedade. Ela distribui e coordena os produtos da atividade humana, que só nela podem perdurar.

Claude Lévi-Strauss em sua clássica Introdução, “A obra de Marcel Mauss", na coletânea de textos de Marcel Mauss intitulada Sociologia e Antropologia, nos lembra o caráter coletivo do sistema simbólico:

"É próprio da natureza da sociedade exprimir-se simbolicamente em seus costumes e em suas instituições; contrariamente, as condutas individuais normais jamais são simbólicas por elas mesmas: são elementos a partir dos quais um sistema simbólico, que só pode ser coletivo, se constrói." (LÉVI-STRAUSS in MAUSS, 1974, p. 7)

O indivíduo projeta na realidade imediata os dados de sua própria consciência. Esse ato, que o filósofo Edmund Husserl chamou "intencionalidade", tenta estabelecer algum sentido para o mundo, um significado, no sentido fenomenológico da palavra, que pode fazer com que o mundo faça sentido perante o ser. Dessa atitude alimenta-se o sistema simbólico, que é coletivo por princípio. O discurso simbólico não é, de modo algum, assimilado imediatamente por imposição categórica. A atribuição de significados, isto é, a compreensão, por parte do receptor, do repertório simbólico, pressupõe a cumplicidade dos receptores no que se refere à sua compreensão. Ou seja, é necessário que vários indivíduos compartilhem os significados simbólicos, permitindo assim, que o indivíduo identifique o símbolo, atribua a ele um sentido e interiorize a representação nele contida.

Max Weber, em Economia e Sociedade, procura equilibrar essa dicotomia colocando a ação social como a ação feita com relação significativa indicada a outro indivíduo, e deixando mais patente o lugar do ser humano como construtor de uma realidade em que ele mesmo produz os significados da sua própria ação. É 
interessante lembrar, que a idéia weberiana de ação social significativamente com relação ao outro encontrou eco na sociologia fenomenológica de Alfred Schutz. Juntamente com a noção de "intecionalidade" de Husserl, a sociologia de Schutz permite uma compreensão dialética - e, portanto, livre de determinismos - das relações entre indivíduo e sociedade.

Ao fenômeno da exteriorização, segundo Berger, vem unir-se, como consequência, o conceito de objetivação. Os produtos do homem, gerados no processo de exteriorização, ganham um caráter distinto daquele mesmo que o produz. Ou seja, esses produtos passam a confrontar-se com o próprio homem que os produziu como algo que lhe é exterior. Esse "algo exterior" ganha caráter de objeto, material ou não-material, capaz de resistir aos desejos do homem que o produziu:

\begin{abstract}
"Embora toda a cultura se origine e radique na consciência subjetiva dos seres humanos, uma vez criada não pode ser reabsorvida à vontade na consciência. Subsiste fora da subjetividade do indivíduo, como um mundo. Em outras palavras, o mundo humanamente produzido atinge o caráter de realidade objetiva." (BERGER, 2012, p. 22)
\end{abstract}

A objetividade a que os produtos culturais produzidos pelo homem passam a ter como característica pode ser mais facilmente vista em produtos materiais. Ao criar um instrumento, como uma ferramenta agrícola, o homem enriquece a totalidade dos objetos físicos e busca facilitar o domínio sobre a natureza. Porém, esse objeto, uma vez usado, não pode ser modificado de imediato e tende a impor a lógica do seu manejo aos que o utilizam, mesmo que essa lógica não tenha sido pretendida por aqueles que originalmente conceberam esse objeto. Hoje, com os meios tecnológicos imbricados no dia-a-dia do homem (celulares, tablets, leitores de livros eletrônicos) essa "imposição da lógica do objeto" aparece muito claramente.

Os elementos não-materiais da cultura também partilham dessa objetividade. A língua é o exemplo clássico desse caso. As regras da expressão falada e escrita, organizadas na gramática, são produtos humanos que dominam, de forma inconsciente diria Ferdinand Saussure, a comunicação entre os 
indivíduos ${ }^{3}$. Além disso, o homem constrói instituições, que no "dia seguinte", o dominam e enfrentam de maneira controladora e intimidatória. Berger levanta a questão, que para as Ciências Sociais parece óbvia, de que "[o] homem produz valores e verifica que se sente culpado quando os transgride" (BERGER, 2012, p. $23)^{4}$. Mas, é importante lembrar também, que o grande Durkheim nos lembra que o poder coercitivo do "fato social" é pequeno comparado com outros elementos desse mesmo fato:

"O poder coercitivo que lhe atribuímos forma até parte tão pequena do todo constituído pelo fato social, que ele pode apresentar também o caráter oposto. Pois, ao mesmo tempo que as instituições se impõem a nós, aderimos a elas; elas comandam e nós as queremos; elas nos constrangem e nós encontramos vantagem no seu funcionamento e no próprio constrangimento. Esta antítese é a que os moralistas têm comumente assinalado entre as duas noções do bem e do dever, que exprimem dois aspectos diferentes, mas igualmente reais, da vida moral. Ora, talvez não existam práticas coletivas que deixem de exercer sobre nós esta ação dupla, a qual, além do mais, não é contraditória senão na aparência. Se não as definimos por este lado especial, ao mesmo tempo interessado e desinteressado, é simplesmente porque ele não se manifesta por sinais exteriores facilmente perceptíveis. O bem traz qualquer coisa de mais interno, de mais íntimo do que o dever, e portanto de menos apreensível.” (DURKHEIM, 1968, p. XXVIII, nota 1)

O caráter de objetividade da cultura, portanto, nos diz que a cultura aparece para o homem como um conjunto de elementos que está fora da sua consciência. Conseqüentemente, a cultura está à disposição para ser apreendida e compartilhada com todos os que se engajarem (conscientemente ou não) na empresa. Partilhar dos elementos culturais, de um universo de objetividades, eis aí o que significa estar imerso na cultura. Assim, é possível afirmar, lembrando Durkheim, que a sociedade está fora do homem com um status de realidade objetiva, mas que, subjetivamente, a sociedade se caracteriza pela sua força coercitiva, e por sua "aparência" opaca:

\footnotetext{
${ }^{3}$ Pode-se até hipostasiar esse caráter de objetividade dos produtos culturais do homem dizendo, como fez a Lingüística Estrutural, que a língua se expressa através do homem, e não que o homem se expresse através da língua.

${ }^{4}$ Sem querer me afastar do tema tratado, é importe ressaltar que a consciência culpada, a despeito de todo o falatório dos nietzchianos, é uma condição sine qua non para a forma gregária de existência humana. Se afastar dessa evidência para entrar numa filosofia de auto-ajuda da "busca da felicidade sem culpas", da "transvaloração de todos os valores", ou ainda a idéia de que a culpa é "uma invenção cristã", é uma atitude infantil e temerária. Basta ler qualquer estudo sério sobre sociopatia.
} 
"[os fatos sociais] resultam de sínteses que têm lugar fora de nós, a respeito das quais não temos nem mesmo a percepção confusa que a consciência dos fenômenos interiores nos pode dar" (DURKHEIM, 1968, p. XXVVII, nota 1).

Partilhar de um mundo de objetividades significa também que os devaneios da consciência solitária se chocam com a realidade efetiva da vida em sociedade, e esta, como nos lembra acima Durkheim, possui uma opacidade que resiste a uma análise por simples introspecção. É necessário sair de si mesmo para compreender fenômenos amplos como os fatos sociais.

A força desse caráter de realidade objetiva que a sociedade possui, pode ser medida pela capacidade da mesma em impor-se à relutância dos indivíduos: a sociedade pune, sanciona e controla a conduta individual, e, em alguns casos, pode mesmo destruir o indivíduo. É preciso lembrar que, apesar dessa objetividade coercitiva estar evidente em alguns casos, todas as instituições sociais possuem esse caráter. Como lembrado acima, o caráter coercitivo, até em instituições criadas em consenso, é necessário para a vida em sociedade. Aos que se esquecem, Berger nos lembra:

"Isto [o caráter coercitivo das instituições] (com toda ênfase) não quer dizer que todas as sociedades sejam variações da tirania. Quer dizer que nenhuma construção humana pode, a rigor, ser chamada de fenômeno social a não ser que tenha atingido aquele grau de objetividade que obriga o indivíduo a reconhecê-la como real. Em outras palavras, a coercividade fundamental da sociedade está não nos mecanismos de controle social, mas sim no seu poder de se constituir e impor como realidade." (BERGER, 2012, p. 25 - grifos do autor)

Essa passagem de Berger revela um conhecimento fundamental que a Sociologia nos legou: o poder que a sociedade possui de aparecer como realidade ao indivíduo. Mesmo no processo de interiorização, os fenômenos sociais mantêm o caráter objetivo, pois, nesse processo, a consciência do indivíduo reabsorve esse mundo de maneira que as estruturas externas (sociais) vêm a determinar as estruturas subjetivas da consciência. A biografia de um indivíduo só pode aparecer como objetivamente real quando compreendida dentro das estruturas do mundo social. Assim, dentro de sua consciência, o individuo como "eu real" pode “conversar" consigo mesmo como padre, por exemplo. Há um diálogo interno, diz George Hebert Mead em Mind, Self and Society, entre as objetivações de si mesmo. No fundo, o homem objetiva uma parte de si mesmo e a defronta, dentro da sua consciência, com figuras disponíveis em elementos objetivos do mundo 
social. $\mathrm{Na}$ interiorização, portanto, o indivíduo apreende vários elementos do mundo objetivado como fenômenos internos da sua consciência, ao mesmo tempo, que os apreende como fenômenos da realidade exterior. Ou seja, "os processos que interiorizam o mundo socialmente objetivado são os mesmos processos que interiorizam as identidades socialmente conferidas" (BERGER, 2012, p. 29).

As identidades admitidas socialmente são absorvidas pelo indivíduo que as defronta e as assume, se quiser manter-se dentro de uma ordem (nomos). A constituição dialética da identidade pode ser resumida quando afirmamos que o indivíduo "torna-se aquilo mesmo que os outros o consideram quando tratam com ele" (Idem). Em Caráter e Estrutura Social, Wright Mills e Hans Gerth, resumem bem essa idéia:

\begin{abstract}
"Seja como for, sabemos que, em algumas situações, o conceito que uma pessoa possui de si mesma está mais ou menos integrado com a imagem que os Outros Importantes têm a seu respeito. A imagem da personalidade que apresenta aos outros, e que tenta fazê-los aceitar ou aprovar, é idêntica à imagem que aspira. Em outras situações, podem-se produzir grandes distinções entre o autoconceito, a imagem apresentada e a imagem desejada." (GERTH e MILLS, 1973, p. 108)
\end{abstract}

Gerth e Mills ainda acrescentam outra informação importante: a possível dificuldade de êxito na socialização total. No equilíbrio dos três momentos da sociedade (exteriorização, objetivação e interiorização) uma socialização pode obter êxito. Um indivíduo totalmente socializado pode ser imaginado como aquele que possui em sua consciência um análogo de cada sentido objetivamente disponível no mundo social. Essa simetria entre os elementos objetivos da sociedade e a consciência do indivíduo é empiricamente não existente e teoricamente impossível de ser demonstrada:

\begin{abstract}
"Não podemos afirmar que todos os elementos da estrutura psíquica normal do adulto estejam socializados em termos de papéis sociais aprovados. Vários impulsos e sentimentos que se estabeleceram na estrutura psíquica, talvez antes do surgimento da pessoa, podem não estar institucionalizados, impossibilitados de agir sob a forma social sobre os papéis disponíveis às pessoas. O processo de orientação, estipulado pela incorporação de papéis e o condicionamento social, não pode ser responsável por tudo aquilo que há no homem; ou seja, as funções pessoais não incluem todos os elementos da sua estrutura psíquica. Por meio de sistemas específicos de recompensas e proibições, aprovações e condenações, o contexto social impede a manifestação de alguns aspectos da estrutura psíquica de determinadas pessoas." (GERTH e MILLS, 1973, p. 92 - grifos do autor)
\end{abstract}

\footnotetext{
${ }^{5}$ A palavra "pessoa", aqui, é empregada por Gerth e Mills no sentido da avaliação do indivíduo
} 
Aqui, vemos a admissão da querela clássica entre indivíduo e sociedade. A socialização do indivíduo ocorre de maneira dialética, pois, como já dito, esse indivíduo é participante do processo e se apropria do mundo social, sendo não só um produto, mas um produtor da ordem social. Por isso, também, a "socialização total" é apenas um conceito que, na realidade empírica, não é possível ser encontrado, ao considerarmos o indivíduo um agente participante da construção social da realidade, e não apenas um membro passivo.

Afirmo, assim, que as "estruturas firmes" da cultura, não possuem toda essa firmeza. Elas não são capazes de se impor totalmente aos indivíduos. Podemos, assim, falar de graus de êxito na socialização. Um maior êxito compreende uma maior simetria entre o objetivo e o subjetivo, assim como num menor êxito a assimetria entre esses dois elementos predomina. Para ser um empreendimento viável e duradouro, a sociedade deve conseguir, no mínimo, interiorizar seus sentidos mais importantes. Do contrário, torna-se difícil estabelecer uma tradição que permita sua persistência no tempo.

A socialização, portanto, deve ser um processo contínuo através de toda a existência do indivíduo. Uma grande questão que perpassa o êxito da socialização é a dificuldade de manter esse mundo social (a ordem social) como algo subjetivamente plausível. A construção desse mundo e a sua manutenção dependem da conversação com aqueles, como citado acima por Gerth e Mills, Outros Importantes (os pais, os mestres, os amigos). A permanência de uma ordem social depende desse tênue fio de conversação.

A construção social do mundo é, em outras palavras, a tarefa humana de dar uma ordem ao seu cosmos; dotar seu mundo de significado. Uma atividade, como diz Berger, "nomizante" ou "ordenadora". Dar ordem à estrutura da realidade é atividade intrínseca a toda espécie de interação social. Como nos diz Weber, toda a ação social supõe que o sentido individual seja dirigido aos outros. A contínua interação dessas ações nos lembra Alfred Schutz, permite que os mais variados sentidos dos atores sociais se integrem numa ordem comum de significado. Como já explicado acima, não podemos imaginar que essa ordem, ou esse nomos, abarque todos os significados individuais. Porém, a atividade 
ordenadora da sociedade pode ser descrita como totalizante, ou seja, o alcance do nomos tende a se expandir para abarcar áreas cada vez maiores de significados comuns.

A atividade ordenadora objetiva, dada a partir do processo de objetivação, tem como grande exemplo a linguagem. Essa imposição da ordem sobre a experiência, que constitui a linguagem, estanca o fluxo ininterrupto da experiência e estabiliza, nomeia e significa uma entidade. Nomear, como atividade ordenadora fundamental, significa não só organizar o caos, mas separar e distinguir coisas. O chamado "princípio de identidade", ou seja, dizer que um item é isto e não aquilo, é a atividade ordenadora primordial da qual se originará todas as outras.

A sociedade, portanto, impõe à experiência uma ordem de interpretação que é compartilhada pelos indivíduos, visando uma totalização dos significados. O conhecimento objetivo, aquele a que todos os indivíduos têm acesso, como objetivação dos significados compostos pela ordem, é em sua maior parte composto por sentidos pré-teóricos. Mesmo sendo o conhecimento teórico uma espécie de guardador das interpretações "oficiais" da realidade, a ordem de interpretação partilhada, em geral, consiste de esquemas interpretativos, máximas morais, coleções de sabedoria tradicional que o homem comum compartilhada com os teóricos. Apesar de existir uma variação quanto aos graus de diferenciação dos corpos de "saber" das várias sociedades, todas elas precisam disponibilizar um "saber" aos seus membros. A integração do individuo numa sociedade depende ipso facto que ele partilhe do saber disponível, ou seja, o indivíduo precisa “co-habitar seu nomos" (BERGER, 2012, p. 34):

\footnotetext{
"Em outras palavras, viver num mundo social é viver uma vida ordenada e significativa. A sociedade é guardiã da ordem e do sentido não só objetivamente nas suas estruturas institucionais, mas também subjetivamente, na sua estruturação da consciência individual.” (BERGER, 2012, p. 34)
}

Está aí estabelecida a dependência mútua entre indivíduo e sociedade. Portanto, separar-se radicalmente do mundo social constitui séria ameaça ao indivíduo, pois ele não perde tão somente os laços emocionais, mas perde sua orientação na experiência, chegando, em alguns casos, a perder o senso da realidade e da identidade. Entra em um estado de anomia. É possível falar em estados de anomia coletivos e individuais, como a perda de status de todo um 
grupo social ao qual o indivíduo pertence; ou perdas estritamente biográficas, como a morte de um ente querido ou um divórcio. Em ambos os casos, a ordem fundamental em termos da qual o indivíduo pode "dar sentido" à sua própria vida e reconhecer sua identidade, estará em processo de desintegração. As consequências psicológicas desse processo são gravíssimas levando o indivíduo a perder suas posturas morais e a tornar-se inseguro quanta às suas posturas cognitivas.

A perda da constante conversação com essa ordem fundamental, a entrada do indivíduo numa desordem de sentidos, pode levá-lo a uma tentativa de ordenação através de uma simbolização individual. Citado anteriormente, LéviStrauss diz que "as condutas individuais normais jamais são simbólicas por elas mesmas" (LÉVI-STRAUSS in MAUSS, 1974, p. 7). São apenas elementos dos quais o sistema simbólico, que só pode ser coletivo, irá se construir. Essa ilusão de um simbolismo autônomo gerado pela tentativa de simbolização individual, diz o antropólogo, permite à sociedade as classificações das condutas consideradas anormais, ou psicopatológicas. As condutas "psicopatológicas" individuais oferecem em cada sociedade uma espécie de equivalente, em escala reduzida, de simbolismos diferentes dos "oficiais". Assim, para Lévi-Strauss, não podemos considerar que o domínio do patológico se confunda com o domínio do individual, pois a classificação dessas perturbações está inserida numa ordem coletiva, num nomos, e, por isso mesmo, as condutas consideradas patológicas se diferenciam nas diferentes sociedades e nos diferentes períodos da história.

A redução do social ao patológico é ilusória na lógica de Lévi-Strauss. Tudo aquilo que pode ser considerado "doença mental”, que é considerado estranho à medicina oficial de uma determinada sociedade, deve ser visto como incidências sociológicas na conduta de indivíduos, cuja história e as constituições pessoais, por inúmeros motivos, se dissociaram parcialmente do grupo, se distanciariam da ordem social estabelecida. Mesmo se admitirmos, diz LéviStrauss, um substrato bioquímico das neuroses ${ }^{6}$, poderia se admitir que essa origem fisiológica apenas cria um terreno favorável, ou "sensibilizador" a certas

\footnotetext{
${ }^{6}$ Fato amplamente aceito hoje na comunidade científica. É curioso que esse mesmo fato tenha sido antecipado, desde os anos 30, nas obras do psicanalista húngaro Lipót Szondi (1893-1986). Szondi, na época, foi rechaçado por parte do estabilishment acadêmico por afirmar que certas condutas psicopatológicas só poderiam ter alguma melhora mediante um tratamento (futuro) através da alopatia.
} 
condutas simbólicas (que se diferenciam das condutas “oficiais"), realçando, assim, a interpretação sociológica desse tipo de conduta.

\title{
2.2
}

\section{O sagrado e a ordem}

A ordem socialmente estabelecida não abrange todas as áreas, todos os "desejos de sentido"7 dos indivíduos. Não há, como já dito, uma ordenação ou simbolização total. Certos aspectos da psique individual permanecerão fora da estrutura simbólica produzida e utilizada socialmente:

\begin{abstract}
“[...] resulta que sociedade alguma pode ser integral e completamente simbólica; ou, mais exatamente, que ela jamais virá a oferecer a todos os seus membros, e no mesmo grau, o meio de utilizar-se plenamente na edificação de uma estrutura simbólica que, para o pensamento normal, é realizável apenas no plano da vida social. Porque, falando com clareza, é aquele a quem chamamos são de espírito que se aliena, pois consente em existir num mundo definível somente pela relação entre mim e o outro. A saúde individual de espírito implica a participação na vida social, como a recusa em prestar-se a essa participação (sempre, porém, em obediência às modalidades por ela impostas) corresponde ao surgimento das perturbações mentais" (LÉVIS-STRAUSS in MAUSS, 1974, p. 10)
\end{abstract}

A ordenação da sociedade, que gera o nomos socialmente estabelecido, pode ser compreendida no seu aspecto mais importante como uma barreira contra o caos: “[...] a mais importante função da sociedade é a nomização" (BERGER, 2012: 35). Quando apartado do sentido gerado por essa ordenação, o indivíduo mergulha num mundo de desordem, incoerência e loucura:

\begin{abstract}
"A realidade e a identidade são malignamente transformadas em figuras de horror destituídas de sentido. Estar na sociedade é ser 'são' precisamente no sentido de ser escudado na suprema 'insanidade' de tal terror. A anomia é intolerável até o ponto em que o indivíduo pode lhe preferir a morte. Reciprocamente, a existência num mundo nômico pode ser buscada a custa de todas as espécies de sacrifício e sofrimento - e até a custo da própria vida, se o indivíduo estiver persuadido de que esse sacrifício supremo tem alcance nômico." (BERGER, 2012, p. 35)
\end{abstract}

\footnotetext{
${ }^{7}$ Uso essa expressão no sentido em que o psicólogo Viktor Frankl dá em sua obra Em busca de sentido: um psicólogo no campo de concentração.

8 O estudo das seitas, a que podemos recorrer à respeitada instituição ICSA (International Cultic Studies Association), nos informa sobre a existência de dois tipos de suicídios, dentro da tipologia de Dukheim, que geralmente acontecem nesse tipo de ambiente. O suicídio de tipo altruísta, de alcance nômico, pode ser visto no exemplo da famosa seita do líder Jim Jones, a "People Temple Christian Church Full Gospel" (ou "Templo dos Povos") em que, no ano de 1978, suicidaram-se 918 pessoas coletivamente. Outro tipo de suicídio encontrado nas seitas é o "suicídio anômico",
} 
A questão da anomia pode ser descrita através do exemplo limite: a morte. A morte constitui para a sociedade um formidável problema não só devido à sua óbvia ameaça à continuidade das relações humanas, mas também porque põe em cheque os pressupostos básicos da ordem sobre os quais descansa a sociedade. Essas "situações marginais" (sensu Karl Jaspers) estão constantemente colocando em risco todo o nomos social, e desvelando a precariedade dos mundos sociais. Num jogo dialético de ordem e caos, o indivíduo se espreita tentado colocar-se dentro da realidade:

\begin{abstract}
"Visto na perspectiva da sociedade, todo nomos é uma área de sentido esculpida de uma vasta massa de carência de significado, uma pequenina clareira de lucidez numa floresta informe, escura, sempre ominosa. Vista da perspectiva do indivíduo, todo nomos representa o luminoso 'lado diurno' da vida, precariamente oposto às sinistras sombras da 'noite'. Em ambas as perspectivas, todo nomos é um edifício levantado frente às poderosas e estranhas forças do caos." (BERGER, 2012, p. 36)
\end{abstract}

Para Berger, seguindo a mentalidade das ciências sociais, toda a sociedade desenvolve mecanismos que ajudam seus membros a permanecerem na realidade (entendida como aquela ordem oficialmente reconhecida), ou a "voltar à realidade", isto é, voltar das situações marginais ao nomos socialmente estabelecido. Mas, na verdade, o importante mesmo é que o mundo social se estabeleça como "coisa óbvia" (BERGER, 2012, p. 37). Não basta que o indivíduo interiorize as características da ordem social oficial como úteis, desejáveis ou corretas. É necessário, em termos de estabilidade social, que esse mesmo indivíduo considere essas características como inevitáveis, como partes integradas do sentido universal da "natureza das coisas". A ordem e suas características, então, passam a ser dotadas de um status ontológico, no sentido em que, que negá-las equivale a negar o próprio ser - o Ser universal, verdadeiro e estável e, conseqüentemente, o que se é nessa ordem.

Toda a vez que o nomos socialmente estabelecido atinge a qualidade de ser aceito como expressão da evidência, ocorre uma fusão do seu sentido com os que são considerados os sentidos fundamentais inerentes ao universo. Nesse momento,

que acontece quando o indivíduo, num lampejo de lucidez, se vê totalmente perdido e não mais encontra sua personalidade dentro daquele sociedade/seita, entrando num caso de anomia total. Um desses exemplos sabidos pertence à seita do líder Rajneesh (depois chamado de Osho) em que um de seus membros, num momento de tomada de consciência da sua situação, preferiu a morte, o suicídio, e cimentou seus pés numa tina e pediu para que alguém o jogasse numa piscina. 
nas palavras de Berger, nomos e cosmos aparecem como co-extensivos. Ou ainda, como diz Schutz, a ordem procura aparecer como uma coisa óbvia. Assim, quando a ordem socialmente estabelecida é aceita como expressão da natureza mesma das coisas, o êxito da socialização alcança um outro nível. O mundo social torna-se “inevitável” e transgredi-lo passa a ser um ato de loucura, não só gerando uma culpa moral, mas, até mesmo, um profundo medo da insanidade, do caos, da anomia. A ordem social, então, passa a ter um status ontológico e negá-la equivale a negar o próprio ser, esse ente que está inscrito na ordem universal das coisas.

As sociedades arcaicas, ou, nas palavras de Eric Voegelin, "sociedades cosmológicas", são exemplos maiores da união entre nomos e cosmos, pois a ordem social faz parte do cosmos; não é apenas um reflexo microcósmico, mas é o cosmos mesmo. Nesses casos, quando a ordem traveste-se de expressão natural das coisas, seja ela entendida cosmologicamente ou antropologicamente, cria-se uma estabilidade, o maior êxito na socialização entre todos os esforços históricos humanos.

A religião, aqui, entra inevitavelmente na nossa discussão. Entendo, juntamente com Mircea Eliade, que a religião pode ser encarada como cosmificação (ou a ordenação) feita de maneira sagrada. Por "sagrado" compreendo a manifestação do supra-natural. Compartilho, aqui, a interpretação de Eliade:

\begin{abstract}
"O sagrado manifesta-se sempre como uma realidade inteiramente diferente das realidades 'naturais' [...] Encontramo-nos diante do mesmo ato misterioso: a manifestação de algo 'de ordem diferente' - de uma realidade que não pertence ao nosso mundo - em objetos que fazem parte integrante do nosso mundo 'natural', 'profano' [...] O homem toma conhecimento do sagrado porque este se manifesta, se mostra como algo absolutamente diferente do profano." (ELIADE, 1996, p. 16-17)
\end{abstract}

Ou seja, a religião pode ser encarada como um empreendimento humano de ordenação do mundo social, empreendimento este que se difere do mundo profano, criando uma significação, uma ordenação mais estável ${ }^{9}$. Sabemos que as diferentes civilizações empregaram essa característica de "sagrado" a diferentes coisas: desde elementos da natureza até ao tempo e ao espaço, passando pela sacralização de seres e espíritos, costumes e instituições.

\footnotetext{
${ }^{9}$ Não entro aqui, ainda, na questão da plausibilidade como mantenedora da ordenação religiosa.
} 
A sacralização do cosmos, portanto, fornece o supremo escudo do homem contra o terror da anomia. Mais do que isso, afirmando juntamente com Eliade, parece que foi só através do sagrado que foi possível ao homem, em primeiro lugar, conceber um cosmos.

\section{3.}

\section{Legitimação e sociedades cosmológicas}

Dentro da discussão sobre a ordem, e mais especificamente, sobre a cosmificação sagrada, devemos estar atentos ao ponto da legitimação. Por legitimação, devemos ter em mente o saber socialmente objetivado que justifica e explica a ordem social. Ou seja, todos os "porquês" sobre a estrutura da realidade social se remetem, em busca de uma resposta, às legitimações. Além disso, é preciso lembrar que as legitimações não têm caráter individual, como construções simbólicas, são sempre coletivas. Também, nem sempre possuem um caráter normativo, não dizem às pessoas o que elas devem ser, apenas propõem o que é. É o caso, por exemplo, da moral do parentesco quando, tratando da proibição do incesto, diz que "Você não pode se deitar com X, sua irmã". A legitimação, como nos lembra Berger, não é uma ideação teórica, mas, em sua grande parte, possui um caráter pré-teórico. Esse fato é amplamente desenvolvido por Lévi-Strauss na sua antropologia estruturalista, que iremos discutir mais a frente.

A simples existência do nomos de uma sociedade já é um fato da sua própria legitimação. O caráter objetivo da ordem social é, em si, um fato legitimador do mundo socialmente construído. Isso porque:

“[...] quando os sentidos das instituições são integrados nomicamente, as instituições são ipso facto legitimadas, até o ponto em que as ações institucionalizadas aparecem como 'evidentes por si mesmas' aos que as executam" (BERGER, 2012, p. 43).

Porém, como já abordado, o êxito da socialização nunca é total, e a fim de minorar os problemas de socialização e controle, outros meios de legitimação são necessários. A herança da ordem pelas próximas gerações deve estar baseada num mecanismo de legitimação que as novas gerações possam "habitar". A sociedade tem que se preocupar com a existência de fórmulas legitimadoras para responder às perguntas que surgirão inevitavelmente nas mentes da nova geração. A 
"sabotagem" da ordem por indivíduos que possuem interesses conflitantes é um fato absolutamente inescapável quando lembramos que a socialização total é impossível.

Dessa maneira, enquanto não houver nenhum desafio à ordem estabelecida, a objetividade/facticidade da ordem social se mantém como elemento legitimador. Do contrário, quando surge uma contestação ou desafio, a facticidade ou objetivação do mundo socialmente construído não mais poderá ser tomada como coisa óbvia. Faz-se necessário uma legitimação de raízes mais profundas, que responda às inquietações tanto da nova geração, quanto da antiga.

Fazendo um apanhado de graus de legitimação, sem nenhuma valoração dos mesmos, podemos ver inicialmente um nível pré-teórico de legitimação como na frase paradigmática "Sempre se fez assim"; passando por um outro nível incipientemente teórico como as máximas morais, os provérbios, a sabedoria tradicional, que, complexificados, podem ser vistos na forma de mitos, lendas ou contos populares. As legitimações explicitamente teóricas são aquelas que separam áreas específicas do "saber". Há ainda as construções altamente teóricas pelas quais a ordem social é justificada e legitimada como um todo. Nas palavras de Voegelin:

\footnotetext{
"A sociedade é iluminada por um complexo simbolismo, com vários graus de compactação e diferenciação - desde o rito, passando pelo mito, até a teoria - e esse simbolismo a ilumina com um significado na medida em que os símbolos tornem transparentes ao mistério da existência humana a estrutura interna desse pequeno mundo, as relações entre seus membros e grupos de membros, assim como sua existência como um todo." (VOEGELIN, 1979, p. 32)
}

A legitimação, que atua na manutenção da realidade tanto no nível objetivo quanto subjetivo, possui uma área maior do que a da religião. Mas, é possível dizer que a religião foi e é o instrumento mais eficaz e amplo de legitimação. Ela consegue relacionar as precárias construções da realidade com os sentidos últimos do cosmos, com o sagrado. A religião consegue a proeza de retirar o caráter construído da ordem social e legitimá-la infundindo-lhe um status ontológico de validade suprema, situando-as num quadro de referência sagrado e cósmico.

Provavelmente, a mais antiga forma dessa legitimação possa ser encontrada naquilo que Eric Voegelin chamou de "sociedades cosmológicas", ou seja, uma sociedade que conceba a ordem social como um reflexo, ou até mesmo, a mesma ordem, da estrutura divina do cosmos. Essa ordem se estrutura dentro da 
relação entre o microscosmo (a sociedade) e a o macrocosmo (a estrutura divina do cosmos).

Voegelin desenvolve sua análise inicialmente no livro A nova ciência da política e, depois, de forma mais pormenorizada, em toda a série Ordem e História, principalmente no Volume I, Israel e a Reveleção. Nesse mesmo livro, na introdução intitulada $A$ simbolização $d a$ ordem, Voegelin inicia suas observações dizendo que o homem não pode ser encarado como um espectador auto-suficiente. Ele, na verdade, é um ator, e pelo simples fato da sua existência, se vê obrigado a desempenhar um papel no "drama do ser", embaraçado por não saber ao certo como desempenhá-lo:

\footnotetext{
"A própria circunstância em que um homem se vê acidentalmente na condição de não ter plena certeza de qual peça e de como deve se conduzir para não estragá-la já é desconcertante; mas com sorte e habilidade ele poderá livrar-se do embaraço e retornar à rotina menos desnorteante de sua vida." (VOEGELIN, 2009, p. 45)
}

O homem, portanto, não pode retirar-se para uma ilha bem-aventurada a fim de recapturar seu eu. É no cotidiano, dentro da sociedade, que ele deve buscar desempenhar seu papel, significar sua existência:

"O papel da existência deve ser desempenhado na incerteza de seu significado, como uma aventura da decisão na linha entre a liberdade e a necessidade" (VOEGELIN, 2009, p. 46).

Assim, o desconhecimento da peça e do papel a serem desempenhados pelo indivíduo se misturam com a incerteza sobre quem ele mesmo é. Porém, como nos diz Voegelin:

“A preocupação do homem com o significado de sua existência no campo do ser não permanece presa nas torturas da ansiedade, mas pode expressar-se na criação de símbolos que se propõem a tornar inteligíveis as relações e as tensões entre os termos distinguíveis do campo." (VOEGELIN, 2009, p. 47)

No processo de simbolização das sociedades cosmológicas, Voegelin identificou quatro características típicas. A primeira delas é a predominância da experiência de participação. A experiência de participação pressupõe a ideia de "comunidade do ser" em que a consubstancialidade dos parceiros se sobrepõe à separação de substâncias. Através dessa simbolização, é possível mover-se dentro de uma comunidade em que tudo possui força, vontade e sentimentos, em que animais e plantas podem ser homens e deuses, em que homens podem ser divinos 
e deuses são reis, "em que o diáfano céu da manhã é o falcão Hórus e o Sol e a Lua são seus olhos, em que unicidade subterrânea do ser é um condutor de correntes mágicas de forças boas ou más que alcançarão subterraneamente o parceiro superficialmente inalcançável, em que as coisas são as mesmas e não são as mesmas, e podem se transformar umas nas outras" (VOEGELIN, 2009, p. 47).

Em linguagem antropológica, a experiência de participação e sua consubstancialidade dos parceiros pode ser definida dentro da questão do mana.

Marcel Mauss, em seu Esboço de uma teoria da magia, diz, baseado em uma série de estudos, que a noção de mana não comporta somente uma idéia de força ou de ser. O mana também poder uma ação, uma qualidade e um estado. A palavra "mana" corresponde, ao mesmo tempo, a um substantivo, um adjetivo e um verbo:

\footnotetext{
"Diz-se que um objeto tem mana para dizer que tem essa qualidade; neste caso, a palavra é uma espécie de adjetivo (que não pode ser aplicado a um homem). Dizse que um ser, espírito, homem, pedra ou rio tem mana - o 'mana de fazer isto ou aquilo'. Emprega-se a palavra mana nas diversas formas das diversas conjugações e então ela pode significar 'ter mana', 'dar mana', etc." (MAUSS, 1974, p. 138)
}

O mana, portanto, permite uma consubstancialidade entre os seres. Ele está em uma infinidade de coisas, sendo uma só e mesma força, não fixa, mas repartida entre os seres, os homens, os espíritos, as coisas, os acontecimentos, e etc. Assim, ele é uma qualidade posta nas coisas, sem prejuízo das outras qualidades dessas mesmas coisas; está superposto à elas. Segundo Mauss, o mana é um acréscimo invisível, aquilo que poderíamos chamar de "maravilhoso", "espiritual”, em resumo, o espírito que, pela sua eficácia, reside em todas as coisas. Ele não pode ser objeto de experiência e não é o "sobrenatural", mas é, ao mesmo tempo, sobrenatural e natural, pois está espalhado por todo o mundo sensível. Nessa mesma perspectiva, vale lembrar Voegelin, que ao se referir à "experiência de participação", diz que ela não é um dado da experiência na medida em que não se apresenta à maneira de um objeto do mundo exterior, mas só pode ser tida como cognoscível, na medida em que se participa dela.

O mana, assim, possui um caráter misterioso, que é capaz de unir ou “consubstancializar" diferentes elementos; pertence às partes e ao todo. Ele possui um poder expansivo, capaz de abarcar áreas cada vez maiores: “[...] uma espécie de éter, imponderável, comunicável, que se expande por si mesmo" (MAUSS, 
1974, p. 141). Além disso, é uma espécie de ambiente, e funciona num ambiente que é todo mana. Como diz Voegelin, referindo-se a experiência de participação: "A grande corrente do ser, em que ele [o homem] flui e que flui nele, é a mesma corrente a que pertence tudo aquilo que flutua até sua perspectiva" (VOEGELIN, 2009, p. 47).

Ou seja, a "comunidade do ser" de Voegelin, depende, em linguagem antropológica, da existência da categoria "mana". A "comunidade do ser" como uma característica da simbolização das sociedades cosmológicas, enuncia as regras da gramática da categoria mana. Para Mauss, nesse tipo de simbolização, que faz parte da magia e da religião, são as idéias inconscientes que agem. O mana, para o antropólogo, é uma categoria fundamental do espírito humano. Numa passagem bem kantiana, Mauss diz que o mana “[...] funciona como uma categoria, tornando possíveis as idéias mágicas como as categorias tornam possíveis as idéias humanas" (MAUSS, 1974, p. 147). O mana, portanto, como todo tipo de simbolização, como disse acima Lévi-Strauss, é uma categoria do pensamento coletivo. Ele permite, por exemplo, que animais e plantas se conectem e tenham poderes; permite pensar, nos utilizando de Voegelin, que a:

“[...] unicidade subterrânea do ser é um condutor de correntes mágicas de forças boas ou más que alcançarão subterraneamente o parceiro superficialmente inalcançável [...]" (VOEGELIN, 2009, p. 47)

Permite, até mesmo, permite a existência de uma grande corrente do ser em que o homem "flui e que flui nele" e que "é a mesma corrente a que pertence tudo aquilo que flutua até sua perspectiva." (VOEGELIN, 2009, p. 47).

Pode se dizer que a categoria mana permite, assim, que esse mundo mágico se sobreponha ao mundo "natural", criando uma espécie de quarta dimensão do espaço, em que a noção de mana exprimiria a "existência oculta". Mas, é preciso lembrar, que para Mauss, o valor mágico das coisas resulta da posição relativa que ocupam na sociedade. Adiantando em dez anos a análise de As formas elementares da vida religiosa, Mauss afirma:

\footnotetext{
"No fundo, trata-se sempre, na magia, de valores respectivos reconhecidos pela sociedade, valores que não se atêm, na realidade, às qualidades intrínsecas das coisas e das pessoas, e sim ao lugar e à posição que lhes são atribuídos pela opinião pública soberana, pelos seus preconceitos.” (MAUSS, 1974, p. 149)
} 
O mana, como categoria do pensamento coletivo, permite fundamentar juízos, impondo uma classificação das coisas. A qualidade de mana permite, de modo arbitrário, juntar e classificar coisas, ordenando-as hierarquicamente. Nesse ponto, podemos citar Voegelin que diz que a segunda característica da simbolização da ordem nas sociedades cosmológicas é a durabilidade e a transitoriedade dos parceiros na comunidade do ser. A relação de durabilidade e transitoriedade cria uma hierarquização:

"Pois as existências mais duradouras sendo as mais abrangentes, fornecem por meio de sua estrutura o arcabouço em que a existência menos duradoura precisa se encaixar se não está disposta a pagar o preço da extinção" (VOEGELIN, 2008, p. 48).

Essa hierarquização através da durabilidade e transitoriedade poder ser resumida em termos matemáticos da seguinte forma:

\section{Homem $<$ Sociedade $<$ Mundo $<$ Deuses}

Ou seja, a existência humana, sendo a mais precária e transitória, é menor que a sociedade e sua possibilidade de ação através do tempo, que é menor que o mundo que dura enquanto as civilizações passam. Esse último não só superado em durabilidade pelos deuses, como talvez seja mesmo criado por eles. Existe, portanto, uma hierarquia da existência, que vai da efemeridade do homem à existência eterna dos deuses. Esse elemento de hierarquização fornece, segundo Voegelin, uma importante força de ordenação da existência do homem. É preciso estar sintonizado com as ordens mais duradouras e mais abrangentes, para que a existência menos duradoura não precise pagar o preço de sua extinção.

A hierarquização dentro da "comunidade do ser" nos informa que os deuses, por duração e abrangência, se encontram, logicamente, acima dos homens. Voltando ao mana, e baseando-se nessa categoria, segundo a lógica de Mauss, a hierarquização parte de juízos sintéticos a priori que linguisticamente podem ser expressos na noção de mana (que seria a expressão de sentimentos sociais que se formam fatal e universalmente a respeito das coisas, de forma arbitrária). Assim, essa categoria que permite uma consubstancialidade entre as coisas, também permite uma hierarquização, mas hierarquização essa, segundo Mauss, baseada na ordem dos sentimentos, das volições e das crenças. Lembrando Voegelin: 
"Apesar da consubstancialidade, há a experiência da existência separada na corrente do ser, e as várias existências distinguem-se por seus graus de durabilidade" (VOEGELIN, 2008, p. 47).

Consubstancialidade e hierarquização, características da simbolização da ordem nas sociedades cosmológicas, podem ser traduzidas, em linguagem antropológica, partindo da visão de Mauss, para a noção de mana.

A terceira característica típica do processo de simbolização, segundo Voegelin, é a tentativa de tornar a ordem essencialmente incognoscível do ser o mais inteligível possível por meio da criação de símbolos que interpretem o desconhecido por analogia com o realmente, ou supostamente, conhecido. Um dessas tentativas é exatamente a que estamos nos detendo aqui, a simbolização da sociedade e de sua ordem como um análogo do cosmos. Na análise do filósofo:

\begin{abstract}
"A primeira forma mencionada [a simbolização cosmológica] é a primeira também cronologicamente. A razão disso não requer explicações muito elaboradas, pois a Terra e o céu são de modo tão notável a ordem abrangente em que a existência humana deve se encaixar para sobreviver que o parceiro avassaladoramente poderoso e visível da comunidade do ser sugere inevitavelmente a sua ordem como modelo de toda a ordem, incluindo a do homem e da sociedade." (VOEGELIN, 2008, p. 50)
\end{abstract}

Esse "parceiro da comunidade do ser" que é o cosmos, segundo o filósofo, parece "sugerir" a sua ordem como modelo para o homem e a sociedade. Então, a sociedade politicamente organizada é simbolizada como um análogo cósmico, um cosmion, fazendo que os ritmos vegetativos e as revoluções celestes funcionem como modelos para a ordem estrutural e procedural da sociedade.

Nos próximos capítulos, iremos observar com mais detalhes a análises de Voegelin sobre as simbolizações baseadas em analogias com o cosmos e a problemática da ordem, e das reincidências simbólicas. 


\section{3.}

\section{Eric Voegelin e a busca pela ordem}

\section{1}

\section{Combatendo o bom combate}

Eric Voegelin (1901-1985) e sua obra podem ser bem definidos, como nos lembra o sociólogo norte-americano Robert Nisbet, como “[...] 'well know' but not 'known well”" (NISBET, 1980, p. 1). Após a publicação do seu The New Science of Politics, Voegelin passa a fazer parte do hall dos grandes scholars, chegando a figurar na capa da revista Time. Mas, como afirmou Nisbet, apesar de ter se tornado bem conhecido, a obra de Voegelin ainda carece, principalmente fora dos Estados Unidos e da Europa, de intérpretes e de acadêmicos que a conheçam profundamente. É verdade que após a publicação de boa parte de seus trabalhos no Brasil, o interesse pela obra do filósofo e cientista político cresceu enormemente em nosso país. Já é possível encontrar monografias, dissertações e teses sobre Voegelin em diferentes universidades brasileiras. Além disso, há uma grande quantidade de trabalhos que circulam pelo mundo acerca das idéias do filósofo. Há, também, um encontro anual na Universidade da Louisiana. É lá, também, que se encontra todo o acervo pessoal de Voegelin, coletado por exalunos e pesquisadores que o colocaram a disposição no The Eric Voegelin's Institute.

Voltando ao caso brasileiro, não posso deixar de citar aqui que o primeiro dos nossos intelectuais a reconhecer a grandeza de Voegelin foi Alberto Guerreiro Ramos. Guerreiro Ramos escreveu uma obra muito interessante intitulada $A$ nova ciência das organizações, numa clara homenagem à Voegelin e a sua $A$ nova ciência da política. $\mathrm{O}$ autor brasileiro apresenta em inúmeros trechos da obra sua 
dívida com o mestre, além de mostrar algumas críticas à obra de Voegelin. Outro fato interessante é que podemos observar em Casa grande \& senzala, do nosso grande sociólogo Gilberto Freyre, mais especificamente citado na bibliografia da obra, um dos primeiros trabalhos de Voegelin, quando ele ainda estava na Alemanha, o Rasse und Staat (1933), demonstrando claramente que Freyre teve contato com a obra do filósofo. Esse trabalho preambular, porém muito potente, de Voegelin, também é citado algumas vezes no clássico de Hannah Arendt, As origens do totalitarismo. É com Rasse und Staat (Raça e Estado) e Die Rassenidee in der Geistesgeschicte von Ray bis Carus (1933) [A história da ideia de raça], dois trabalho muito críticos do racismo reinante na época, que a vida de Voegelin começa a ficar ameaçada, passando a ser impossível continuar na Alemanha após a ascensão do partido Nacional Socialista e da publicação do seu extraordinário trabalho Die politischen Religionen (1938) [As religiões políticas]. Assim, o filósofo consegue se exilar nos EUA, e passa inicialmente a lecionar em Harvard através de um convite de seus amigos Arthur Holocombe e Schumpeter. Após esse período, em 1942, Voegelin passa a fazer parte da Universidade da Louisiana, passando dezessete anos nessa instituição e publicando as obras que estabeleceram sua reputação: The New Science of Politics (1952) e os três primeiros volumes de Order and History: Israel and Revelation (1956), The World of the Polis (1957) e Plato and Aristotle (1957). Em 1958, Voegelin é chamado de volta à Alemanha, convidado para lecionar na Universidade LudwigMaximilian, em Munique, assumindo a cátedra que estava vacante desde a morte de Max Weber e criando o Instituto de Ciência Política. Porém, em 1969, Voegelin retorna definitivamente para os Estados Unidos, passando a lecionar no Hoover Institute na Standford University como "Distinguished Scholar". Voegelin permaneceu até sua morte, em 1985, nessa instituição.

Se há algo que podemos notar com clareza na obra de Voegelin é a sua profunda honestidade intelectual, a "intellektuelle Rechtschaffenheit" de Weber, que Voegelin faz questão de frisar em Reflexões Autobiográficas. Outro ponto que é notável nos escritos do filósofo é a vastidão de conhecimento, uma erudição impressionante comparável a de seu mestre Weber. Voegelin, sobre o tema, afirma: 
"[...] devo salientar que outra importante influência de Max Weber foi a abrangência de seus estudos comparados. No que me diz respeito, Weber comprovou de uma vez por todas que, no campo das ciências sociais e políticas, não se pode ser uma acadêmico qualificado sem conhecer profundamente o assunto. Isso significa adquirir o conhecimento comparado das civilizações - não apenas da civilização moderna, mas também da medieval e da antiga, e não apenas do Ocidente, mas também do Oriente Próximo e do Extremo Oriente - e, em contato com as diversas especializações científicas, manter atualizada esse conhecimento. Quem assim não procede não tem o direito de dizer-se um cientista empírico, e decerto deixa a desejar como acadêmico da área." (VOEGELIN, 2008, p. 33)

Voegelin é duro em suas palavras, mas é coerente em sua vida e obra. Dedicando todo o seu tempo aos estudos e à escrita, o pensador deixou uma vasta obra, totalizando 34 volumes no The Collected Works of Eric Voegelin. Não afirmava ser necessário um vasto conhecimento por simples diletantismo, ou nas palavras de Nietzsche, para ser um "historiador antiquário". O filósofo usava seus atributos para combater o bom combate. Voegelin foi testemunha da ascensão dos regimes mais genocidas da história, o Comunismo e o Nacional Socialismo. Dentro das universidades e dos meios pensantes, ele se deparava com um crescimento exponencial da defesa das ideologias que davam base para esses regimes, que criavam um "clima de opinião na academia. Voegelin, assim, passará toda a sua vida num combate com todas as formas do que ele chamou de “deturpações da realidade" (VOEGELIN, 2009, p. 34). Em The New Science of Politics, já em 1952, Voegelin criticou duramente o positivismo ainda reinante nas Ciências Sociais e defendeu uma Ciência Política crítica das ideologias, em busca por uma ordem saudável para a sociedade. Em Science, Politics and Gnosticism (1968) o filósofo dá o start para sua crítica da desordem espiritual moderna, ou seja, todos os "-ismos" (Nazismo, Comunismo, Marxismo, Positivismo...), chegando a chamar Marx de “intellektueller Schwindler”, que numa tradução livre significa "impostor intelectual”.

Não pretendo aqui entrar nos pormenores da crítica do filósofo à modernidade. O que é importante por agora é situá-lo historicamente. Voegelin não esteve sozinho nessa empreitada. Na introdução da importante obra The quest for community: a study in ethics of order and freedom (1953) de Robert Nisbet, Ross Douthat situa a obra de Nisbet e de Voegelin: 
"The intellectual conservatism that flowered unexpectedly, like a burst of tulips from a desert, in the aftermath of the Second World War was preoccupied above all else with revising the story that modernity told about itself. Twenty years of totalitarism, genocide, and total war had delivered hammer blows to the Whig interpretation of history: after Hitler, and in Stalin's shadow, it was no longer possible to be confident that the modern age represented a long, unstoppable march from the medieval darkness into the light. Instead, there was a sudden demand for writers who could explain what had gone wrong, and why - and just how deep the rot really ran.” (NISBET, 2010, p. 1)

A crítica da modernidade, da visão iluminista e evolucionista da história, são pontos importantes no pensamento desses autores do pós-guerra. Pensadores como Voegelin e Nisbet (além de muitos outros, como John Hallowell, Will Herberg, Milton Hindus, Friedrich von Hayek, Russell Kirk, Thomas Molnar, Gerhart Niemeyer, Richard Weaver) levantaram a ideia de como o "progresso" e o "iluminismo" produziram as câmaras de gás e os gulags. No fundo, uma busca por uma ordem mais humana e justa estava no programa desses ditos conservadores do pós-guerra. É interessante observar que o livro A nova ciência da política de Vogelin foi publicado em 1952 e, logo no ano seguinte, 1953, Nisbet publica seu The quest for community.

É preciso, no entanto, observar que a contribuição de Voegelin que irei tratar aqui se limita a sua interpretação do que chamou da "ordem das sociedades cosmológicas" e de sua explicação da existência de reincidências de ordem. É sabido que sua obra é de difícil leitura (nas mais diferentes línguas). Não sou um especialista na obra do filósofo, pois isso irá demandar ainda muitos anos de estudo. Portanto, a minha contribuição aqui está restrita aos pontos apresentados acima.

\section{2}

\section{A história das ordens}

Mas, como os volumes de Ordem e História se encaixam na proposta de Voegelin? O filósofo, desde A nova ciência da política, que, na realidade, se compõe de uma série de conferências com o título de "Representação e Verdade", procurou demonstrar que há sim uma ordem que não é fabricada pelo homem, uma ordem que é dada pela realidade. Como o próprio autor resumiu a ideia, dizendo: 
"Ordem é a estrutura da realidade como experienciada pelo homem, bem como a sintonia entre o homem e uma ordem não fabricada por ele, isto é, a ordem cósmica" (VOEGELIN, 2008, p. 117 - grifos do autor).

Desta forma, Voegelin tenta compreender como as diferentes civilizações e sociedades entram em sintonia (ou não) com essa ordem não produzida pelo homem. Assim, por exemplo, a modernidade (e os regimes totalitários) para Voegelin está(ão) dentro de uma desordem causada pela des-sintonia com as fontes de ordem. Um exemplo icônico para o filósofo são as ideologias (comunismo e nazismo) que tentam criar uma segunda realidade ${ }^{10}$, se apoiando em construções falaciosas para se opor à realidade da experiência, numa obsessiva “recusa de perceber". Nas ideologias, segundo Voegelin, parte da realidade é suprimida para tornar possível a edificação de um falso sistema. As ideologias modernas suprimem diferentes partes da realidade, mas um item está sempre presente em todas: a exclusão da "experiência da tensão do homem em direção ao plano divino de sua existência" (VOEGELIN, 2008, p. 146). Portanto, Voegelin trava uma batalha contra qualquer tentativa de estruturação de ordem que não contemple o que ele acredita ser a realidade com todos os seus componentes. Para ele, a tentativa de suprimir partes da realidade por "construções falaciosas" leva, por exemplo, a uma desumanização do homem, tão característica dos regimes totalitários e de suas ideologias fundadoras.

Seguindo a lógica de Voegelin, era preciso, portanto, empreender um enorme esforço para recompor uma possível história da ordem, ou das ordens. Em Ordem e História, Voegelin, através de uma vasta gama de documentos (fontes primárias, trabalhos de grandes especialistas e etc), cumpre essa tarefa, deixando àqueles que se interessem, um estudo sobre como os indivíduos, desde os tempos da Mesopotâmia até as barbáries do século XX, empreendem a tarefa fundamental de ordenar a sociedade e a sua própria vida.

Voegelin, então, se dedica a tarefa de discernir no curso da história as formas simbólicas com que os seres humanos têm organizado sua existência pessoal e social. Israel e a revelação, o primeiro volume de Ordem e História, examina as civilizações do antigo Oriente Próximo, com seu locus cósmico-divino

\footnotetext{
${ }^{10}$ Voegelin retira essa expressão da obra $O$ homem sem qualidades do escritor austríaco Robert Musil.
} 
da ordem, bem como o locus histórico da ordem empreendido por Israel (fato que já era atestado na sociologia da religião weberiana).

$\mathrm{Na}$ introdução desta obra, intitulada "A simbolização da ordem" (VOEGELIN, 2009), Voegelin expõe de maneira clara o arcabouço conceptual no qual sua visão da ordem vai se desenvolver. Para Voegelin, há uma só ordem que é, ao mesmo tempo, divina, cósmica, antropológica e política: é a ordem universal do ser. A estrutura e o alcance dessa ordem são experimentados e simbolizados pelos elementos primordiais: Deus e seres humanos, mundo e sociedade, que formam uma "comunidade primordial do ser" (Idem). Porém, os seres humanos nunca compreendem a estrutura total da realidade. Quando chegam a apreender o significado, eles criam símbolos para tornar inteligível a ordem necessariamente incognoscível do ser mediante o uso da analogia com o que já é conhecido. O “drama da humanidade" (Ibdem), para Voegelin, é que apesar dos seres humanos serem atores e não espectadores na "comunidade do ser" (a realidade e todos os elementos que a compõem), eles não conseguem compreender totalmente o drama da existência, nem o seu próprio papel dentro dele. Portanto, é através da simbolização e da ordenação (mediante o uso da analogia com o que já é conhecido) que o indivíduo dota de significado sua existência. Essa tentativa de simbolização e ordenação deve, para Voegelin, estar em sintonia com a ordem total da realidade, que inclui aquela não fabricada pelo homem.

A história, segundo o filósofo, é a dimensão que abarca a existência humana sob condições políticas mutáveis, pela ascensão e queda de civilizações, mas é, de modo especial, o movimento geral da vida humana, numa direção dotada de sentido, numa luta pela sintonia com os "parceiros na comunidade do ser", uma luta pela verdade em relação a Deus (ou aos deuses), aos seres humanos, à sociedade e ao mundo. Uma busca pela ordem verdadeira. Voegelin tentava, assim, incluir outras dimensões às análises políticas e filosóficas que, em sua época, estavam comprometidas com movimentos ideológicos de massa. O editor de Israel e a revelação, Maurice P. Morgan, diz em sua introdução:

"Eric Voegelin, um dos principais filósofos políticos de sua época, empreendeu seu estudo em resposta aos movimentos ideológicos de massa do começo do século XX que tiveram sucesso em impor uma cegueira espiritual e uma 'amnésia' social. Seu objetivo foi recuperar a verdade, uma abertura à realidade que incluísse as dimensões pessoais, sociais, históricas e ontológicas reveladas pelas experiências e simbolizações 'mais diferenciadoras' deixadas pela marcha 
humana no curso do tempo. Seu estudo seria a ocasião de uma redescoberta da ordem verdadeira como um remédio para a crise moderna: "não uma tentativa de explorar as curiosidades do passado, mas uma investigação da estrutura da ordem em que vivemos no presente'." (VOEGELIN, 2009, p. 10)

Voegelin compreende que as sociedades têm criado, desde o início, uma série de ordens que simbolizam a verdade pertencente à ordem do ser, da qual a sociedade é considerada participante. O interessante na obra do filósofo é que o exame desse "rastro de símbolos" deixado na história, leva não só à descoberta do processo histórico de simbolização, mas também ao processo correspondente da consciência humana a ele subjacente. Robert Nisbet foi categórico ao dizer:

\footnotetext{
"Voegelin has done more than any other philosopher with whom I am acquainted - with exception of St. Augustine - to bring an empirical, reasoned conception of individual consciousness as the dynamo of history" (NISBET, 1983, p. 117)
}

A temática da simbolização e da consciência humana é riquíssima na obra de Voegelin. Tratarei dessa temática mais à frente. Antes, portanto, é importante frisar que ao analisar o processo histórico de simbolização, o filósofo utiliza termos como diferenciação, salto no ser e sintonia com o ser. As diferentes tentativas de simbolização formam a base de uma história que parece inicialmente poder ser vista como uma passagem de símbolos “compactos" para símbolos mais "diferenciados". Apesar de, em determinados casos, essa passagem poder ser aplicada $^{11}$, ela não pode ser vista como um sentido atribuído à história. Ou seja, Voegelin não acredita que a história possua um sentido, que, no caso, poderia ser a passagem progressiva da simbolização compactada para a simbolização diferenciada. No volume IV de Ordem e História, "A era ecumênica", o filósofo é categórico ao dizer que é impossível deduzir um eidos da história, pois ela não está para o homem como um objeto em que se possa conhecer seu início e seu fim. O homem, na perspectiva de Voegelin, é um participante no fluxo dos acontecimentos históricos. Sendo o futuro incognoscível, a história está aberta para a eternidade. Essa ideia nos lembra da frase do grande historiador alemão Leopold von Ranke: “Todas as épocas são iguais perante a Deus”. Não há como prever um futuro em que a simbolização será mais diferenciada, onde a verdade

11 A análise da passagem símbolos compactos para diferenciados parece ter sido muito influenciada pela obra de Weber e a ideia do progressivo desencantamento. Voegelin, em A nova ciência da política, aplica a ideia de desdivinização para explicar essa diferença entre compactação e diferenciação. 
sobre a existência será descoberta ou que o homem terá sua redenção na terra. Assim, a atribuição de um sentido para o desenrolar histórico, tão presente nas filosofias da história e nas ideologias, é, para Voegelin, uma falácia ${ }^{12}$.

\title{
3.3
}

\section{A simbolização compacta e as sociedades cosmológicas}

Ao falar de simbolização compacta, nos dizeres de Voegelin, me refiro a criação de símbolos e de ordem empreendidos pelas sociedades tradicionais, e pelas "primitivas": as "sociedades cosmológicas". No seu primeiro volume da série Ordem e História, o pensador identifica o simbolismo compacto como fato existente nos impérios do Antigo Oriente Próximo. É a partir do simbolismo imperial da Mesopotâmia e do Egito que Voegelin desenvolve sua análise sobre esse tipo de simbolização compacta. É verdade que Voegelin, anos depois, irá dizer que a simbolização cosmológica (compacta) também pertence às sociedades tribais ou "primitivas" (cf. VOEGELIN, 2008). A única ressalva feita pelo autor, é que para analisar os simbolismos cosmológicos no nível tribal é preciso observar a differentia specifica introduzida pela simbolização de tipo imperial no Antigo Oriente Próximo, e diferenciá-la daquela simbolização empreendida em sociedades de organização não imperial:

\begin{abstract}
"Quando redigi o primeiro volume de Ordem e História, o limite do meu horizonte eram os impérios do Antigo Oriente Próximo. Identifiquei o simbolismo cosmológico que encontrei ali com o simbolismo imperial da Mesopotâmia e do Egito. Com base na expansão de nosso conhecimento préhistórico e arqueológico nos últimos anos, posso agora dizer que praticamente todos os símbolos que aparecem no Antigo Oriente Próximo têm suas raízes no Paleolítico, atravessando a pré-história por meio do Neolítico, datando aproximadamente vinte mil anos antes dos impérios do Antigo Oriente Próximo. Surgiu aí um novo problema: era preciso desvincular a questão geral do simbolismo cosmológico no nível tribal, que datam da Idade da Pedra; e, por fim, identificar a differentia specifica introduzida pela fundação dos impérios, como no caso do Egito. Coletei o material para realizar esse projeto e espero poder um dia publicar minhas descobertas"13 (VOEGELIN, 2008, p. 126)
\end{abstract}

\footnotetext{
12 "The process of history, and such order as can be discerned in it, is not a story to be told from the beggining to its happy, or unhappy, end; it is a mystery in process of revelation" (VOEGELIN, 1974, p. 6).

${ }^{13}$ Infelizmente, Voegelin não teve tempo de empreender essa análise.
} 
O fato de Voegelin não ter trabalhado com sociedades tribais está relacionado com a história anterior a confecção de Ordem e História. Antes do projeto sobre a ordem, Voegelin, já nos Estados Unidos, é contratado para escrever uma História das Idéias Políticas. A idéia era formar um manual para uso escolar que substituísse o manual já um pouco envelhecido do conhecido professor de filosofia George Sabine (1880-1961). Essa História estava sendo planejada para ser uma série em três volumes, mas ele acabou escrevendo oito. Quando no oitavo volume, Voegelin percebeu que o projeto havia dado errado, porque, segundo o mesmo, não há continuidade entre as idéias filosóficas, entre as doutrinas filosóficas, muito menos entre as idéias políticas, se você não conseguir conectar uma à outra através da experiência. Ou seja, o filósofo acreditava que a experiência política, a realidade dos fatos políticos é que é o fundo do qual emergem as idéias políticas, e só através da história dessas experiências é que se poderia ter uma ideia de continuidade entre os pensamentos. Por outro lado, esses puros fatos não poderiam ser investigados em si mesmos, mas somente em documentos já auto-expressivos. Resultado: as próprias doutrinas políticas tinham de ser encaradas não como doutrinas, mas como testemunhas auto-expressivas da realidade política e social de cada época. Então, Voegelin tinha de tirar de dentro delas o conteúdo de experiência ao qual ele estava se referindo. Isso complicaria o trabalho de tal maneira que o filósofo teve de abandonar essa História das Idéias Políticas, que só foi publicada após sua morte, e começar um trabalho completamente diferente, que foi o Ordem e História, sua grande obra. Assim, Ordem e História é também uma tentativa de restabelecer a conexão (que o autor acredita rompida na modernidade) entre as experiências e os símbolos.

Desta maneira, podemos compreender por que Voegelin não pode lidar com culturas tribais. Como o método dele só admitia os documentos autoexpressivos, e como na organização tribal esses documentos estão inexistentes (não há documento em linguagem teorética), então esse tipo de organização ficou excluída. Apesar de existir uma ordem ou um modelo de ordem, evidentemente, nas sociedades "primitivas", ela se expressa somente nas instituições, nos costumes, nas práticas e etc. Voegelin, portanto, exclui essa análise por um motivo prático. Se ele não encontrasse os documentos que já são autoexpressivos, podendo ser entendidos como Aristóteles entendia as idéias dos 
sábios, ou seja, como materiais com os quais você vai montar uma confrontação dialética; se não houvesse essa exclusão, ou seja, se ele lidasse com documentos que não são automaticamente auto-expressivos como, por exemplo, um edifício, uma pintura, uma música, ele teria de produzir o equivalente verbal do que esses elementos estão querendo dizer, e isto tornaria o trabalho tão imenso que seria praticamente impossível terminá-lo. A seleção do material que ele faz tem um fundamento muito claro. Voegelin não vai trabalhar com documentos mudos, por assim dizer, que tenham de ser interpretados. Ele só trabalha a partir das interpretações já existentes, e mesmo assim o material é enormemente vasto.

Procurando esses documentos auto-expressivos das sucessivas ordens que a humanidade conheceu, os primeiros que aparecem não se referem às culturas tribais, mas às grandes civilizações do Oriente, como a Mesopotâmia e o Egito. É ali que ele começa a investigação. Quando ele pergunta que modelo de ordem organizava estas sociedades, ele vai ver, em primeiro lugar, que todas essas civilizações, todas essas sociedades, se entendiam a si mesmas como modeladas por uma ordem cósmica. Ou seja, isso significa que para essas sociedades o mundo humano (o que chamaríamos hoje de cultura e sociedade) está inserido numa ordem cósmica que abarca o universo inteiro. Essa ordem deixa de fazer uma clara distinção, tão característica da era moderna, entre as esferas humana e não-humana (ou "natural") da realidade empírica, não distingue também o empírico do supra-empírico, nem o mundo dos homens do mundo dos deuses. A ordem social, nesses termos, não apenas segue a ordem cósmica, mas a ordem social é um elemento da ordem cósmica e serve, portanto, para preservá-la. Portanto, essas sociedades se caracterizavam por uma visão completamente unitária, ou monista, do mundo. Uma visão de que há uma união permanente dos acontecimentos humanos com as forças divinas que permeiam o universo. Essa continuidade é efetuada, ou restabelecida, repetidas vezes no ritual religioso.

Recorrendo às mais antigas fontes como as inscrições egípcias, babilônicas, assírias ou persas, Voegelin verifica que a ordem dessas sociedades é invariavelmente interpretada como a representação da ordem cósmica na sociedade humana. A organização de tipo imperial a que essas sociedades recorriam é vista como análoga ao cosmos, como um pequeno mundo que reflete a ordem do mundo maior e envolvente. Assim, o ato de governar passa a ser uma 
tarefa de assegurar a harmonia entre a ordem da sociedade e a ordem cósmica; o território do império é uma representação analógica do mundo com todos os seus quadrantes; as grandes cerimônias do império representam o ritmo do cosmos; os festivais e os sacrifícios são uma espécie de liturgia cósmica, uma participação simbólica do cosmion (sociedade) no cosmos; e o governante representa a sociedade, absorvendo em si a representação da ordem cósmica.

Ao nível do indivíduo, esse tipo de universo garante um segurança de significado maior. Se, como já dito no primeiro capítulo, a religião empreende da maneira mais estável a tarefa de significar e ordenar uma sociedade, num universo em que o cosmos é sacralizado as barreiras contra a anomia são muito eficazes. Num ambiente de sociedade cosmológica, tudo possui um sentido remetido a ordem mesmo do cosmos. Mas, Berger nos lembra:

\begin{abstract}
"Isso [tudo ter um sentido] não que absolutamente dizer que nada de terrível possa acontecer ao indivíduo ou que lhe está assegurada uma felicidade permanente. Quer dizer que tudo o que venha acontecer, embora possa ser terrível, tem sentido para ele, por estar relacionado ao significado último das coisas." (BERGER, 2012, p. 127)
\end{abstract}

\title{
3.4
}

\section{A mitologia e a condição humana}

Para examinarmos como tudo isso funciona na prática, é importante começarmos analisando as narrativas míticas que estruturam essa ordem. O escrito mítico mais conhecido desse tempo e região é o chamado Enûma elish (ou "Quando acima"). Essa é a principal fonte de conhecimento da cosmologia mesopotâmia. Composta por sete "tábuas" de escrita cuneiforme, o Enûma elish possui um pouco mais de mil linhas e foi descoberto pelos exploradores Austen $\mathrm{H}$. Laytard, Hormuzd Rassam e George Smith entre o final do século XIX e início do século XX. Baseio-me, aqui, na obra publicada pelo reconhecido Oriental Institute da Universidade de Chicago, The Babylonian Genesis, escrita pelo pesquisador Alexander Heidel. Além disso, farei uma comparação com os escritos do Gênesis hebraico, que muito guardou das histórias babilônicas, como diz Heidel: 
"Of all Semitic inscriptions composed in cuneiform writing few have awakened as great a general interest as the epic known among the Babylonians and Assyrians as Enûma elish ("When above"), which takes its name from the opening words of the poem. Aside from linguistic considerations, this widespread popularity of Enûma elish is in part due to its great significance for the study of the theogonic and cosmogonic views of Mesopotamians, and thus for a comparative study of ancient Near Eastern religion in general; but above all else its due to the fact that Enûma elish presents quite a number of analogies to the first two chapters of the Book of Genesis." (HEIDEL, 1951, p. 1)

Quando lemos o texto do Livro do Gênesis, como nos lembra Heidel e Voegelin, observamos inúmeras semelhanças com o Enûma elish e com o Mito de Adapa. Na Bíblia, Deus cria o homem à sua imagem, para assemelhar-se a ele, e lhe dá o domínio sobre o resto da criação. Porém, a semelhança não é completa, pois Deus havia retido o conhecimento do bem e do mal e ordenado ao homem, sob a ameaça de morte no mesmo dia, que não comesse da “árvore do conhecimento". O tentador (na figura mítica da serpente), porém, sabe a versão verdadeira: o homem não morrerá quando comer da árvore do conhecimento; ele, na verdade, se tornará mais semelhante aos deuses, conhecendo o bem e o mal. Assim, o homem come o fruto proibido e, de fato, não morre como Deus the havia ameaçado. Ao invés disso, nos diz o narrador bíblico, surge uma ameaçada para Deus: "Eis que o homem se tornou como um de nós, conhecedor do bem e do mal. Agora, pois, cuidemos que ele não estenda a sua mão e tome também do fruto da árvore da vida, e o coma, e viva eternamente." (Gn 3, 22-23) ${ }^{14}$.

O mito de Adapa, apresentado juntamente com o Enûma elish, foi por muito tempo (e ainda é) debatido por especialistas que ali reconhecem a versão babilônica original da história de Adão e de sua queda. Voegelin nos conta que o Adapa do mito foi inicialmente caracterizado como o "primeiro homem" ou a "semente da humanidade". Numa comparação filológica posterior, descobriu-se que a ideia de "semente" não equivaleria, no contexto do mito, à ideia de "pai", mas de "descendente" do homem. Assim, Adapa é um ser semidivino, numa mistura entre um homem e o deus da sabedoria, chamado Ea. Adapa, então, foi dotado, através de seu pai Ea, de sabedoria, mas, por causa do seu "lado humano", não possuía vida eterna. Ea, no entanto, o criou para ser um líder entre a

\footnotetext{
${ }^{14} \mathrm{O}$ plural utilizado na citação possui diferentes interpretações. Pela interpretação oficial romana, há o uso do plural para se referir à Deus de maneira "majestática" ("plural majestático"), ou para se referir as três pessoas da trindade: Pai, Filho e Espírito Santo. Como o narrador do Gênesis se utilizou de fontes babilônicas, alguns dizem que o plural se refere mesmo à diferentes deuses, como na narrativa do Enûma elish.
} 
humanidade e o aprimorou para esclarecer os decretos da terra. Adapa foi um sacerdote e governante na cidade de Eridu, a cidade de seu pai e deus Ea.

O narrador do mito conta que um dia, quando Adapa estava pescando no golfo, uma rajada repentina do vento o submergiu. Assim, furioso, Adapa, dotado de poderes mágicos, amaldiçoou o vento sul e, pela maldição quebrou-lhe a asa, causando, desse modo, uma perturbação no cosmos. Após sete dias, Anu, considerado o "Senhor do céu", reparou que o vento sul não estava soprando e, informado da razão, convocou Adapa à sua presença. Ea, no mesmo instante, equipou Adapa, seu filho, com bons conselhos, dizendo-lhe como se portar para conquistar amigos no céu e, ainda, alertando-o a não provar nenhuma comida ou bebida que lhe fosse oferecida, pois seriam a comida e a água da morte. Mediante os conselhos de Ea, Adapa conseguiu acalmar a ira de Anu, que refletia sobre o que fazer com o réu. Anu sabia que o dano original havia sido causado por Ea, quando o mesmo deu a um homem, seu filho Adapa, os segredos do céu e da terra (dotando-o com a sabedoria e com poderes mágicos). Adapa havia se tornado conhecido e forte; a melhor coisa a se fazer seria torná-lo de vez um deus completo. Assim, Anu ordena que a comida e a água da vida lhe sejam trazidas. Seguindo os conselhos de Ea, Adapa, no entanto, se recusa a beber ou a comer. Anu, então, libera-o para voltar à sua terra e concede a Eridu, a cidade de Adapa, a liberdade do serviço compulsório, e concedeu ao semideus a glória do sumo sacerdócio até os dias mais distantes, indo indicar aos homens a organização correta da sociedade.

Após observarmos os mitos narrados tanto no Gênesis hebraico, quanto na épica babilônica, podemos passar a compreender a maneira como Voegelin interpreta esses elementos fundamentais da estruturação da ordem:

\footnotetext{
"Ao lidar com seu significado precisamos portanto distinguir o conteúdo da história mítica da experiência por ela simbolizada, pois se selecionarmos partes do mito sem cautela crítica e as examinarmos como se fossem proposições num discurso, carregando o seu próprio significado, chegaremos a conclusões duvidosas (que, de fato, foram tiradas) como, por exemplo, que os babilônicos acreditavam que a morte era consequência de um conselho deliberadamente enganoso de Ea ou de um erro de cálculo por parte de Ea e Adapa. Interpretações desse tipo tratam o mito como se ele fosse um estudo empírico do comportamento humano, o que um mito de deuses e semideuses obviamente não é." (VOEGELIN, 2009, p. 67)
} 
O filósofo diz que é preciso "distinguir o conteúdo da história mítica da experiência por ela simbolizada". Como dito anteriormente, Voegelin quer restabelecer a conexão entre as experiências e os símbolos: "Os símbolos do mito devem ser relacionados à experiência expressa" (VOEGELIN, 2009: 67). Nas duas narrativas é possível ver que a existência humana é privada da duração eterna que pertence aos deuses. Embora isso esteja claro, às vezes é difícil identificar as causas da privação. Voegelin identifica duas características básicas. A primeira é o sentimento do "poderia ter sido". Já a segunda, se relaciona com a ideia de consubstancialidade, a que já me referi no capítulo anterior. A sensação de consubstancialidade parece, nessas narrativas, prevalecer fortemente, superando a ideia de separação das existências. O homem, portanto, parece não ver causas importantes para que ele também possua o mesmo status que os deuses. Porém, vemos que há uma rivalidade com os deuses nessa busca irresistível pela vida eterna: Ea, ao aconselhar seu filho Adapa, lhe nega a vida eterna quando ela é oferecida por Anu. Deus, no Jardim do Éden, adverte Adão para as consequências da atitude de comer do fruto proibido e depois o expulsa do Paraíso.

No caso do mito de Adapa, como vimos, o deus da sabedoria, apesar de "prometeicamente" equipar seu filho Adapa como um líder entre a humanidade, acaba lhe negando a característica que o faria um deus completo. Poderíamos perguntar: será que a verdadeira sabedoria, encarnada em Ea, não anseia por um prolongamento da existência além da duração que lhe cabe? Voegelin afirma que seria ir longe demais admitir que Ea queria que isso tivesse acontecido. Há, para o filósofo, a caracterização de um engano, um "poderia ser", mas que a narrativa mítica parece vislumbrar uma vontade de ser homem e não de ser deus; uma aceitação da condição humana. Mas, Voegelin ainda se questiona:

“Ainda assim, há algo estranho nessa advertência contra a comida e a água da morte, pois as substâncias míticas não são venenos ministrados num banquete renascentista. E como sua consequência não é um ataque cardíaco, mas a mortalidade, que dano elas poderiam causar ao Adapa mortal?" (VOEGELIN, 2009, p. 68)

Voegelin, então, remetendo-se ao Gêneses bíblico, diz que a "morte" estabelecida como castigo para a transgressão de Adão não se refere à mortalidade, a passagem da existência, mas a uma "queda espiritual da condição do ser" (VOEGELIN, 2009). Da mesma maneira, apesar do mito de Adapa não 
levantar a questão da "queda do ser", há a curiosa advertência de Ea contra a "comida da morte", que, no fim, terminará com a rejeição da "comida da vida". Para Voegelin, portanto, o problema da "queda do ser" no mito de Adapa está formulado, mas de maneira compacta. O narrador do Gênesis, no entanto, expõe esse problema de maneira mais articulada e diferenciada, permitindo observar a faceta do interdito como uma "tentação" para homem (encarnada na sedução da serpente). O resultado, diz Voegelin, porém, em ambas as narrativas é o mesmo: "o domínio do homem é a compensação analógica para a ordem eterna" (VOEGELIN, 2009, p. 69).

Essa diferenciação entre homens e deuses cria um domínio humano que precisa ser preenchido de significado e ordem que, para as sociedades cosmológicas, deve ser obtido através da sintonia com a ordem cósmica sagrada, da qual a sociedade é uma compensação analógica. Assim, a existência menos duradoura que não possui a "vida eterna", simbolizada nas figuras míticas de Adapa e Adão, ou seja, a existência humana, precisa se sintonizar com a ordem daquelas existências mais duradouras e eternas, os deuses e o cosmos sagrado em que habitam.

Nos dois mitos narrados já foi possível ver as características típicas da simbolização na ordem cosmológica enunciadas por Voegelin, e citadas no capítulo anterior. São elas:

$1^{\circ}$ ) A predominância da "experiência de participação": seja o homem o que for, ele sabe que é uma parte do ser. A “comunidade do ser" é vivenciada com tal intimidade que a consubstancialidade dos parceiros se sobrepõe à separação de substâncias. Nos mitos de Adão e Adapa, a experiência da consubstancialidade entre eles e os deuses se sobrepõe, inicialmente, a separação desses "parceiros". Os dois poderiam ter se igualado aos deuses se não houvesse um interdito, simbolizado, no caso de Adão, pela queda, e no caso de Adapa, pelo conselho de seu pai Ea.

$2^{\circ}$ ) A preocupação com a duração e a passagem; a durabilidade e a transitoriedade dos "parceiros na comunidade do ser": apesar da consubstancialidade, há a experiência da existência separada na corrente do ser. Essas existências distinguem-se por seus graus de durabilidade, como vimos logo acima. Assim, a 
existência humana, sendo a mais precária e transitória, é menor que a sociedade e sua possibilidade de ação através do tempo, que é menor que o mundo que dura enquanto as civilizações passam. Esse último não só superado em durabilidade pelos deuses, como, nas sociedades cosmológicas, é experienciado como sendo criado por eles. Essa hierarquia da existência fornece uma importante força de ordenação da existência do homem. A existência humana, passageira e impotente, precisa se sintonizar com as ordens mais duradouras e mais abrangentes, para que ela não pague o preço da sua própria extinção.

$3^{\circ}$ ) A tentativa de tornar a ordem essencialmente incognoscível do ser o mais inteligível possível por meio da criação de símbolos que interpretem o desconhecido por analogia com o realmente, ou supostamente, conhecido: nos dois mitos acima a linguagem e os símbolos usados são todos conhecidos e utilizados na vida diária das sociedades. Além disso, na perspectiva de Voegelin, as sociedades cosmológicas experienciam a realidade como qualquer outra sociedade, mas ela a simbolizada de forma compacta, com o conhecimento disponível sobre a estrutura da realidade captado por homens daquele período.

\section{5}

\section{Cosmos e ordem: a simbolização política}

Voegelin, ainda assim, dá um grande peso para a simbolização da ordem política. Numa passagem muito interessante, o filósofo relaciona a criação de um governo com a criação do mundo. Diz ele:

"Estabelecer um governo é uma experiência de criação do mundo. Quando o homem cria o cosmion da ordem política, ele repete analogicamente a criação divina do cosmos. A repetição analógica não é um ato de imitação fútil, pois ao repetir o cosmos o homem participa, na medida permitida por suas limitações existenciais, da criação da própria ordem cósmica. Além disso, ao participar da criação da ordem, o homem experimenta a sua consubstancialidade com o ser do qual ele é uma parte criada. Desse modo, em seu esforço criativo, o homem é um parceiro no duplo sentido de uma criatura e um rival de Deus." (VOEGELIN, 2009, p. 63)

Nos mitos narrados tanto no Gênesis bíblico, quanto no babilônico, já conseguimos identificar a ideia do homem como uma criatura e um rival dos 
deuses. Na simbolização da ordem política, em que, para Voegelin, estabelecer um governo é uma experiência de criação do mundo, há, na civilização mesopotâmica, um escalar crescimento em que a realidade política e a simbolização passam a se encontrar, gerando um núcleo bem definido (mais diferenciado, diria Voegelin) de símbolos na época da Primeira Dinastia Babilônica (1830-1531 a.C.), mais especificamente durante o reinado de Hamurabi, que foi, do ano de 1792 a 1750 a.C., o sexto rei dessa Primeira Dinastia.

Com o crescimento das cidades-estado independentes na civilização sumério-acadiana, os impérios passam a se formar, e paralelamente cresce a ideia do império como um análogo do cosmo e de sua ordem. No preâmbulo do famoso Código de Hamurabi, encontra-se, com clareza, essa simbolização:

\footnotetext{
"Quando o sublime Anu, rei dos Anunnaki, e Enlil, senhor do céu e da terra, que determina os destinos do território,

Atribuíram a função de Enlil [governo] sobre todo o povo a Marduk, o filho primogênito de Enki, fizeram-no grande entre os Igigi,

Quando chamaram a Babilônia pelo seu nome exaltado, fizeram-na inigualável no mundo,

Quando em seu meio estabeleceram para ele um reinado perene cujas fundações são tão sólidas quanto o céu e a terra -

Então Anu e Enlil chamaram-me, Hamurabi, o príncipe obediente, venerador dos deuses, pelo meu nome,

Para fazer a justiça prevalecer na terra, para destruir os maus e os perversos, para impedir que os fortes oprimissem os fracos,

A fim de que eu me elevasse como o sol sobre os povos de cabeças escuras, para iluminar a terra." (BOUZON, 1980, p. 20)
}

Essa passagem do Código de Hamurabi contém o claro paralelismo entre a criação da ordem, a fundação da Babilônia sob o reinado de Marduk (deus supremo do panteão babilônico) no céu, e a criação do reino terreno da Babilônia sob o comando de Hamurabi ${ }^{15}$. Uma organização política, naturalmente, existe no tempo e origina-se no tempo como uma unidade reconhecível. Mas, no estilo cosmológico de simbolização, segundo Voegelin, não há um fluxo de tempo histórico organizado por um evento originador. Como se pode observar no Código, a fundação de um governo é concebida como um evento na ordem cósmica dos deuses, da qual o evento terreno é a expressão análoga. Assim, é

\footnotetext{
${ }^{15}$ Voegelin lembra que é possível encontrar um eco desse paralelismo na concepção de uma "Jerusalém celeste" que desce sobre a terra em Gálatas 4,26 e Apocalipse 21.
} 
possível dizer que as duas primeiras linhas do Código se referem à esfera cósmica, as três posteriores à esfera política e terrena, e as três últimas linhas referem-se ao domínio resultante.

Além disso, é interessante perceber que a própria organização espacial do império refletia a organização espacial do cosmos. Assim, na civilização babilônica, a ordem espacial do universo, dada através das revoluções dos principais corpos celestes do leste para o oeste, cria o sistema dos quatro pontos cardeais, dos quatro cantos do mundo e das quatro regiões correspondentes. $\mathrm{O}$ império terreno corresponde à ordem celestial na medida em que toda a terra está dividida, na concepção babilônica, nos quatros domínios de Acad (sul), Elam (leste), Subartu e Gurtium (norte) e Amurru (oeste). Os babilônios, através de uma "geografia celestial elaborada" (VOEGELIN, 2009, p. 73), ainda encontravam no céu os originais correspondentes à configuração terrena: os rios Tigre e Eufrates são identificados a constelações definidas, da mesma forma que as grandes cidades; até a Lua é dividida em regiões correspondentes aos cantos da terra. É sabido o espantoso desenvolvimento da astronomia e da astrologia, que estavam aí imbricadas, na Babilônia. Em suma, nos dizeres do autor:

\begin{abstract}
"A vida do homem e da sociedade é experimentada como ordenada pelas mesmas forças do ser que ordenam o cosmos, e as analogias cósmicas tanto expressam esse conhecimento como integram o social na ordem cósmica. Os ritmos das estações e da fertilidade na vida vegetal e animal, bem como as revoluções celestes de que esses ritmos dependem, devem ser entendidos como a ordem que fornece as analogias. O conhecimento da ordem cósmica nesse sentido, em especial com relação à astronomia, era fortemente desenvolvido na civilização sumero-babilônica" (VOEGELIN, 2009, p. 85)
\end{abstract}

Voegelin, então, pontua o que é para ele essa simbolização cosmológica:

“A simbolização cosmológica não é nem uma teoria, nem uma alegoria. Ela é a expressão mítica da participação, experimentada como real, da ordem da sociedade no ser divino que também da ordem ao cosmo." (VOEGELIN, 2009, p. 74)

Essa "expressão mítica da participação" mantém o cosmo e o cosmion político como existências separadas, mas há uma espécie de "fluxo de ordem" que flui de forma intensa entre essas duas esferas. Como vimos no Código de Hamurabi, o governo de Marduk sobre toda a terra é estabelecido no céu, enquanto a ascensão do rei terreno ao poder, Hamurabi, é apenas a realização da 
nomeação divina. Assim, o que Voegelin chama de "participação na comunidade do ser”, ou seja, a união entre essas duas esferas, terrena e cósmica, é tão íntima que, de fato, apesar da separação das substâncias, império e cosmos são parte de uma única ordem abrangente.

Na simbolização cosmológica, uma das características recorrentes é o "simbolismo do centro" ou omphalos. Em uma tradução direta, o omphalos, ou ônfalo, significa "umbigo do mundo". É através desse ônfalo que as forças cósmicas fluem para a ordem social. Na civilização babilônica, como vimos no preâmbulo ao Código de Hamurabi, a Babilônia torna-se inigualável no mundo quando foi estabelecida "no meio do mundo" como um reino perene. O próprio nome, Bab-ilani, significava de fato "Portão dos Deuses". É na Babilônia que se encontra o omphalos, é por meio dela que as forças cósmicas ordenam o mundo através de um fluxo de ordem. Mircea Eliade comenta sobre o "simbolismo do centro" ou omphalos:

\begin{abstract}
"Essa coluna cósmica só pode situar-se no próprio centro do Universo, pois a totalidade do mundo habitável espalha-se à volta dela. Temos, pois, de considerar uma seqüência de concepções religiosas e imagens cosmológicas que são solidárias e se articulam num 'sistema', ao qual se pode chamar de 'sistema do Mundo' das sociedades tradicionais: (a) um lugar sagrada constitui uma rotura na homogeneidade do espaço; $(b)$ essa rotura é simbolizada por uma 'abertura', pela qual se tornou possível a passagem de uma região cósmica a outra (do Céu à Terra e vice-versa; da Terra para o mundo inferior); (c) a comunicação com o Céu é expressa indiferentemente por certo número de imagens referentes todas elas ao Axis mundi: pilar (cf. a universalis columna), escada (cf. a escada de Jacó), montanha, árvore, cipós etc; $(d)$ em torno desse eixo cósmico estende-se o 'Mundo' ('nosso mundo') - logo, o eixo encontra-se 'ao meio', no 'umbigo da Terra', é o Centro do Mundo” (ELIADE, 1996, p. 38 - grifos do autor)
\end{abstract}

A Babilônia é o "Portão dos Deuses", o ponto de conexão entre as duas partes (Céu e Terra), em que o "fluxo do ser flui do cosmo para o império" (VOEGELIN, 2009: 75). Esse símbolo de ordem é muito recorrente. Ele pode ser encontrado na Hélade grega, onde a pedra em Delfos marcava o centro do universo; pode ser visto também no "Templo de Jerusalém" em que o rochedo sobre o qual o tempo se ergueu era chamado de "umbigo da Terra". Desta maneira, a criação de um governo se assemelha a criação de um mundo, ordenando a realidade e integrando-a com o cosmos. 


\section{6}

\section{A estrutura da realidade, a consciência e a busca pela ordem}

Nos trechos acima, vimos que Voegelin pretendeu, com seu Ordem $e$ História, restabeler a conexão entre a experiência e os símbolos: "Os símbolos do mito devem ser relacionados à experiência expressa" (VOEGELIN, 2009, p. 67). Para que possamos compreender essa ideia mais a fundo, devemos adentrar na teoria da consciência desenvolvida pelo filósofo. Muito influenciado por William James, Edmundo Husserl e Alfred Schutz, além dos clássicos como Platão, Aristóteles e Tomás de Aquino, Voegelin defende a ideia de que a consciência é feita de experiências de participação. Essas experiências podem ser do tipo de uma anamnesis, ou seja, uma rememoração ou re-lembrança de fatos do passado, sejam eles fatos relacionados à objetos do mundo exterior ou relacionados com experiências que pouco têm a ver com objetos apreensíveis pelos sentidos. Essa característica da teoria de Voegelin contrasta com ideia de Husserl da consciência como percepção sensível de objetos do mundo exterior. Voegelin incluiu na formação da consciência o fato da "rememoração", por exemplo, de contos de fadas que havia lido na infância:

"[...] passei por experiências como a ansiedade e a fascinação de estar nas fronteiras do mundo conhecido com Hans Christian Andersen em um de seus contos de fada [...] A consciência é feita de experiências desse tipo. Tal é a verdadeira consciência de um homem, a menos que se insista que a minha infância foi completamente diferente da de qualquer outra criança na história da humanidade. Essas experiências de participação em diversas áreas da realidade são o horizonte da nossa existência no mundo. O que deve ser sublinhado são as experiências (no plural) da realidade, a abertura do homem a todas elas e seu esforço de mantê-las em equilíbrio." (VOEGELIN, 2008, p. 113 - grifos do autor)

Ou seja, Voegelin concebe a consciência como o palco das experiências de participação na realidade. O centro da consciência está na experiência de participação, na realidade do contato do homem com a realidade que está fora dele. Esse contato entre essas duas esferas só é possível, segundo o autor, porque há uma consubstancialidade entre a consciência e a realidade que ela experiência: "Se o homem não fosse consubstancial com a realidade que experiência, não poderia experiência-la" (VOEGELIN, 2008, p. 114). A experiência é o que está 
entre o sujeito e o objeto da participação. Portanto, ela não está nem no sujeito nem no mundo dos objetos, mas no que Voegelin chamou de "Intermédio", ou metaxy, isto é, o pólo entre o homem e a realidade que ele experiência.

Separar esses pólos, para o filósofo, implica num descarrilamento (deraiment) da razão. Não se pode hipostasiar esses dois pólos da experiência, sob pena de falsear a realidade. A condição humana é a existência no In-Between, no Intermédio, na metaxy, da imanência e da transcendência, da mortalidade e da imortalidade, da natureza e da cultura. É preciso reconhecer todos os níveis da realidade que o homem experiencia. Assim, o problema da realidade experienciada passa a ser o fluxo de realidade participativa, em que a realidade passa a iluminar-se a si mesma na consciência humana. Não há, na teoria de Voegelin, uma consciência humana que está consciente da realidade exterior à ela. A consciência faz parte do processo da realidade, iluminando a realidade através do que Voegelin chamou de metaxy (um termo originalmente usado por Platão):

\begin{abstract}
"This consciouness of the metaxy constitutes an area of reality in which we can speak of that reality of the tension in consciousness as a reality. And what that reality reveals is that it is a tension between man who has the consciousness and something that moves him to be conscious and to be conscious of more [...] Let me use here a simple diagram: The tension goes toward the 'ground', in Plato and Aristotle; and at the other end of the tension is 'man'; and there is a movement and countermovement. And, we might say, the area of that movement and countermovement, that is what Plato and Aristotle would call psyche" (VOEGELIN, 2004b, p. 363 - grifos do autor)
\end{abstract}

A necessidade do "fundamento" ("ground") caracterizada pela posse da ignorância - ideia aristotélica que inspira Voegelin - move o homem a buscar as respostas. A busca do "fundamento", que pode ser caracterizada como a busca pela resposta da questão clássica colocada por Leibniz "Por que existe o Ser e não o Nada?", coloca o homem em contato com essa tensão (metaxy) experiencial entre ele (a sua consciência, a psyche) e a realidade que lhe permite captar as respostas que o homem procura.

Como da realidade das sociedades cosmológicas (e, para Voegelin, da realidade como um todo) fazem parte tanto a presença humana como a divina, a consciência humana que a experiencia busca pela ordem na estrutura cósmica sagrada, trazendo para a sociedade a mesma ordem que estrutura o cosmos.

Ainda assim, a consciência humana é, para Voegelin, a luz que guia o homem no drama que é a sua vida, mas é uma luz difusa, que não reflete as coisas 
do mundo com a necessária clareza. O drama do homem é espelhado nos símbolos da experiência que ele mesmo criou para compreender o sentido da trama que o permeia.

Voegelin, em inúmeros momentos na sua vasta obra, expõe os elementos de sua antropologia filosófica, Mas, como analisa Gordon (2011), em nenhum lugar, o filósofo faz isso de forma tão concisa e clara quanto no ensaio "Equivalences of Experience and Symbolization in History":

"Existence has the structure of the In-Between, of the Platonic metaxy, and if anything is constant in the history of mankind it is the language of tension between life and death, immortality and mortality, perfection and imperfection, time and timelessness, between order and disorder, truth and untruth, sense and senselessness of existence; between amor Dei and amor sui, l'ame ouverte and l'ame close; between the virtues of openness toward the ground of being such as faith, love and hope, and the vices of unfolding closure such as hybris and revolt; between the moods of joy and despair; and alienation in its double meaning of alienation from the world and alienation from God" (VOEGELIN, 2004a, p. 119).

A antropologia filosófica de Voegelin se baseia diretamente na tradição platônico-aristotélica e judaico-cristã. Ou seja, o ponto nevrálgico desta antropologia é a metaxy, ou participatio no conceito latino, a participação humana no divino. A antropologia filosófica tradicional, ou pré-moderna, a que Voegelin se reporta, é uma combinação de como o homem era visto na sociedade helênica e na sociedade israelita. Em termos gerais, o homem era experimentado pelos filósofos como um ser constituído de razão (noûs). Já na sociedade israelita, o homem era experimentado como o ser a quem Deus dirige sua palavra, também chamado de ser "pneumático", que está aberto ao Logos divino. Assim, Voegelin compõe sua antropologia filosófica, como nos diz Gordon:

\footnotetext{
“A razão (noûs) e o espírito (pneuma) são, segundo Voegelin, os dois modos da constituição humana generalizados na idéia de homem. $\mathrm{O}$ autor diz que as experiências da razão e do espírito concordam no ponto em que o homem experiencia a si próprio como um ser que não existe por si mesmo. A percepção humana mais básica e original é a de que existimos num mundo já dado. Esse mundo em si existe em razão de um mistério. O nome deste mistério, ou da causa desse ser do mundo, do qual o homem é um componente, é chamado de Deus. Segundo a antropologia clássica, o homem é um ser teomórfico, ou seja, criado à imagem de Deus (imago Dei).” (GORDON, 2011, p. 28 - grifos do autor)
} 
A existência humana, portanto, está imbricada pela compreensão do universo que a rodeia. Esse universo é experienciado através de uma consciência que está dentro do processo da realidade que é, ele mesmo, um Intermédio.

Essa realidade que é a metaxy, é experienciada da mesma maneira, segundo Voegelin, pelo homem "primitivo", pelo homem das sociedades tradicionais de tipo imperial como a Babilônia, pelo filósofo grego, pelo místico cristão, e pelo homem "imanentista" moderno. O que ocorre entre os períodos históricos são processos de compactação e diferenciação da simbolização dessa realidade. Ainda segundo o autor, foi Aristóteles o primeiro a perceber que a realidade que tinha por objeto de sua análise filosófica era a mesma realidade que os pensadores "teologizantes", que o antecederam, haviam experienciado e expressado sob a forma de mito:

\footnotetext{
"Quando, no mito de Urano e Gaia, os pensadores da Grécia arcaica expressam suas experiências da origem do ser, estão à procura do plano divino do ser a cuja busca o próprio Aristóteles também se dedica, e que acaba por identificar como Noûs. O philomythos é para ele algo como um philosophos. Em seus últimos anos de vida, Aristóteles foi ficando cada vez mais fascinado pelo mito como fonte de sabedoria, pois essa forma de expressão pode por vezes ser mais abrangente que as estruturas da realidade diferenciadas pelo filósofo. Ele compreendeu as relações entre experiências e simbolizações nos vários níveis de compactação e diferenciação que estão subentendidas em meu conceito de equivalência. O conceito de equivalência expressa a identidade reconhecível da realidade, experienciada e simbolizada em diversos níveis de diferenciação." (VOEGELIN, 2008, p. 160)
}

Essa citação resume de maneira interessante o conceito de "equivalência" na filosofia de Voegelin. Ao tratar acima dos mitos da Babilônia, vimos que o Gênesis da Bíblia possuía uma série de símbolos comuns com a simbolização presente no Enûma elish e no mito de Adapa. Quando Voegelin diz que na mitologia grega há uma busca pela origem do ser, que é a mesma empreendida por Aristóteles e reconhecida pelo mesmo, podemos também dizer que a mitologia babilônica expressa na figura da Adapa e o Gênesis hebraico e o seu Adão, também tenta responder ao desejo de se conhecer a origem do ser, através do plano divino. Nas duas narrativas, como vimos, há a narrativa simbólica da origem da condição humana, ou, nos dizeres de Voegelin, da "queda espiritual da condição do ser". Como mortal, o homem vê-se diferente de seus deuses, e se coloca no cosmos num estrato inferior a eles. A condição do ser, se "no início dos 
tempos" poderia se equipar a dos deuses, "hoje" já é a de uma queda para uma situação de mortalidade e impotência.

O mito de Adapa não possui a mesma estrutura de diferenciação que o mito de Adão. Numa situação mais "compacta”, o mito de Adapa é a narrativa típica da civilização cosmológica. Já o Gênesis hebraico é a simbolização em um estado de maior "diferenciação". Para Voegelin, essa diferenciação acontece quando há um “salto no ser" (VOEGELIN, 2008).

O "salto no ser", tomado da expressão de Kierkegaard, "salto do Sprung", é, antes de tudo, a experiência do ser divino como transcendente ao mundo. Quando a mentalidade cosmológica é "substituída" por essa "tomada de consciência”, ou seja, quando a divinização do cosmos passa a dar lugar há existência de Deus único e transcendente a ordem cósmica, há um "salto no ser":

"É preciso reconhecer a existência de uma pluralidade de simbolismos. Uma teogonia de Hesíodo, por exemplo, simplesmente não é uma filosofia no sentido aristotélico, ainda que a estrutura da realidade expressa pelo mito e pela filosofia seja a mesma - uma identidade de estrutura que Aristóteles já reconhecera. Foram surgindo problemas que tentei expressar por meio de conceitos como o de experiência compacta (ou primária) do cosmos e o das diferenciações que levam à verdade da existência no sentido dos clássicos gregos, dos profetas de Israel e do cristianismo primitivo. Para caracterizar a transição decisiva da verdade compacta à verdade diferenciada na história da consciência, empreguei, na época o termo salto no ser, emprestando a palavra salto do Sprung de Kierkegaard." (VOEGELIN, 2008, p. 122)

Em Israel e a Revelação, Voegelin trata Israel como a primeira civilização em que ocorreu esse "salto no ser". Israel e seus profetas trouxeram uma das primeiras diferenciações entre a temporalidade e a ordem espiritual, ou seja, a crença num deus supracósmico, transcendente a todas as representações possíveis, tornava impossível que a verdade trazida por essa religiosidade fosse representada pelo imperium mundi. Agora, cabia aos homens a observância da lei divina e o ato de servir ao Deus único. Essa "novidade" abria uma enorme separação entre essa nova mentalidade religiosa e a concepção antiga caracterizada pela crença em forças cósmicas, ora propícias, ora adversas, que pesam sobre o destino humano e entre cujas exigências a comunidade deveria abrir seu caminho; além da crença na possibilidade de representação temporal da ordem divina, como, por exemplo, o reconhecimento da encarnação de certos deuses em reis no Império, ou a deificação mesma do imperador. 
Pode-se ver, aqui, então, o que Voegelin chamou por "desdivinização" em A nova ciência da política, conceito muito influenciado por seu mestre Weber, que já via em Israel o início do processo de “desencantamento do mundo". Para o filósofo, esse primeiro "salto no ser" inicia o processo pelo qual a antiga visão religiosa, a "religião da magia" como diria Weber, dá lugar a crença no Deus único e transcendente, trazendo uma mentalidade que impossibilita a representação imanente daquilo que é da ordem divina, retirando o divino do quadro histórico e cósmico em que o aprisionara a religiosidade antiga. Gerando, assim, a concepção de um deus supracósmico e transcendente a todas as representações possíveis. Nas palavras do autor:

[...] entender-se-á por desdivinização o processo histórico pelo qual a cultura do politeísmo morreu de atrofia experiencial e a existência humana na sociedade foi reordenada mediante a experiência do destino do homem, pela graça de Deus que transcende o mundo, ruma à vida eterna numa visão beatífica. (VOEGELIN, 1979, p. 84)

O "salto no ser" figurado em Israel trouxe ao mito do Gênesis facetas diferenciadas que não existiam na simbolização compacta dos mitos babilônicos. Os profetas de Israel ainda trarão a questão da "revelação", um novo tipo de simbolização da ordem. A busca pela origem da condição do ser, bem representada nessas duas narrativas, é uma das temáticas mais constantes nas mais diferentes simbolizações. Para Voegelin, essa busca é constante, e, logicamente, a condição do homem é a de um ser mortal, uma situação que está inscrita na estrutura da realidade e que, portanto, será experienciada sempre da mesma maneira. Assim, se, para as sociedades cosmológicas bem como para Israel, dá estrutura da realidade participam, em situação de metaxy, homem e Deus (ou sociedade e Ordem), a situação humana será experienciada como uma "queda espiritual do ser". Explicada de maneira compacta na simbolização do mito de Adapa e de forma diferenciada no Gênesis hebraico, o resultado porém é o mesmo: o domínio do homem pode ser, no máximo, uma compensação analógica para a ordem eterna, pois o homem não mais participa nesse mundo, no mesmo nível que os deuses, da eternidade. Essa percepção da estrutura da realidade, contida na mitologia da Babilônia e na diferenciação articulada pelo narrador do Gênesis, é aquela mesma que Voegelin aceita na sua antropologia filosófica: "Esse mundo em si existe em razão de um mistério. O nome deste mistério, ou da 
causa desse ser do mundo, do qual o homem é um componente, é chamado de Deus" (GORDON, 2010, p. 28). Assim, as esferas da imanência e transcendência são partes da realidade, do Todo, para Voegelin. Ele, como Aristóteles, reconhece no mito as verdades simbolizadas de maneira compacta (como o "mundo dos homens" e o "mundo dos deuses"), que serão, como no exemplo, diferenciadas a partir do "salto no ser" dos profetas de Israel (o "homem" e o "Deus único"). O próprio autor nos diz:

"Não há o menor sentido em supor, por exemplo, que os sacerdotes egípcios que escreveram a Teologia de Mênfis ou os sacerdotes mesopotâmicos que desenvolveram o Livro dos Reis da Suméria fossem incapazes de articular as experiências de forma clara por terem problemas diferentes dos de um Voltaire, um Comte ou um Hegel. O que é experienciado e simbolizado como realidade, em um processo de progressiva diferenciação, é a substância da história." (VOEGELIN, 2008, p. 124)

A substância da história é o que experienciado e simbolizado. O grande comentador de Voegelin, Eugene Webb nos lembra:

"From Latin substantia: standing under. In Voegelin's use the underlying reality of anything. Not to be confused with the use of the term in traditional metaphysics, where it refers to an independently existing entity." (Webb, 1981, p. 288).

Assim, a substância da história é a "realidade fundamental", é a própria estrutura da realidade que é experienciada. Essa "realidade fundamental", a que Voegelin chama de "comunidade primordial do ser", fazem parte, segundo ele, Deus e homem, mundo e sociedade, numa estrutura quaternária, num simbolismo universal da cruz (que iremos ver mais à frente).

Portanto, todo homem, em qualquer época, irá experienciar essa realidade, simbolizando-a de diferentes formas. A equivalência das ordens, assim, é explicada por Voegelin através da ideia de que todos os homens de todas as épocas experienciam uma mesma realidade, a realidade formada, primordialmente, por Deus e homem, mundo e sociedade. Apenas, esses homens simbolizam-a de maneiras diferentes. Chamamos essas formas de simbolização de mito, revelação, filosofia, poesia e etc. Ainda citando Webb, que diz:

"In Voegelin, the principle that two symbolisms are equivalent, despite differences of individual form, if they refer recognizably to the same structures in reality." (WEBB, 1981, p. 281) 
A equivalência entre duas formas simbólicas se dá, portanto, ao observarmos que elas se referem a mesma realidade. A teogonia de Hesíodo e as especulações filosóficas de Aristóteles se equivalem, pois se referem a mesma realidade, que para Voegelin é a única que possuímos: a estrutura quaternária entre Deus e homem, mundo e sociedade, a "comunidade primordial do ser".

Ao nos depararmos com formas simbólicas que não contemplam algum destes componentes da realidade, segundo o filósofo, estaremos observando a construção de um sistema falso, um descarrilhamento da razão. Pois, a realidade, para o autor, irá se manter pelo o que ela é, e não por o que algum pensador acha a respeito. Assim, certas simbolizações e tentativas de ordenação podem e de fato não levam em consideração essa estrutura da realidade descrita por Voegelin. Esse fato acontece, segundo o filósofo, principalmente nas ideologias (principalmente no Nazismo e no Comunismo), em que não há o reconhecimento de uma ordem verdadeira, mas há, na verdade, uma deturpação da realidade (uma criação de uma Segunda Realidade), gerando consequências muito graves para a sociedade e para os indivíduos. 


\section{4.}

\section{Lévi-Strauss: forma e significado}

\section{1}

\section{O antropólogo contra a corrente}

Claude Lévi-Strauss dispensa apresentações. Sendo ainda considerado por grande parte da comunidade científica como o maior antropólogo já existente, o francês é um grande exemplo de pensador em busca dos dados invariantes nas mais diferentes culturas.

Herdeiro da tradição sociológica francesa, Lévi-Strauss reconheceu inúmeras vezes sua dívida com Durkheim e Mauss. O estruturalismo lévistraussiano, foi uma das maiores contribuições já empreendidas na história da disciplina e, sabidamente, influenciou muitos outros campos de conhecimento, como a psicologia, a literatura, a crítica de arte e até a biologia.

Quando falamos aqui de "Estruturalismo", estamos nos colocando numa análise através da história de ideias, e situando esse conceito em um contexto específico: a concepção estruturalista francesa na antropologia lévi-straussiana, que desabrochou por volta dos anos 60. O estruturalismo se espalhou por uma série de áreas e adentrou a teoria de uma gama de intelectuais sendo, portanto, mais um estilo de pensamento, que nasceu da linguística moderna e desabrochou na França, principalmente nos anos 60, do que um movimento unificado ou uma escola.

Desde os anos 40, o ambiente intelectual francês estava impregnado pelas ideias existencialistas de Jean-Paul Sartre (1905-1980) e Maurice Merleau-Ponty (1908-1961), que, resumidamente, podemos colocar em duas palavras: humanismo e historicismo. Dois conceitos consagrados nas frases de Sartre, "O 
existencialismo é um humanismo" e "A existência precede a essência". Além e dentro dessa concepção, o humanismo, tanto na filosofia como nas ciências sociais, subtendia a primazia da consciência, ou, usando o jargão mais filosófico, do sujeito. Assim, para o existencialismo, herdeiro direto da fenomenologia de Edmundo Husserl (1859-1938), o cogito (herdado de Descartes), ou seja, a substância pensante, é sempre intencional; não há sujeito sem objeto (não há cogitum sem cogitatum). Esse sujeito fenomenológico é a base do sujeito sartriano.

Lévi-Strauss, então, dirá que esse sujeito sartriano, herdeiro da matriz fenomenológica, é um enfant-gaté da reflexão, que atrapalha uma séria busca das estruturas mentais que estão, por definição, aquém da esfera da consciência, quebrando com a tradição humanística ocidental e seu tradicional interesse pela consciência. As palavras do intelectual brasileiro José Guilherme Merquior, que foi aluno de Lévi-Strauss, resumem bem a relação entre consciência e estrutura no pensamento do antropólogo:

"Pois as estruturas [para Lévi-Strauss] não podem de forma alguma ser 'vivenciadas' num estado de consciência - são apenas experimentadas, 'sentidas', sem nunca se tornarem objetos para a mente consciente." (MERQUIOR, 1991, p. 58)

Além disso, a análise do contexto acadêmico da época demonstra que estruturalismo era sinônimo de rigor, e uma análise rigorosa (nos anos 60) exigia que o foco na ação intencional, ou mesmo consciente, fosse abandonado, para que se pudessem identificar as motivações ocultas da conduta humana. Portanto, a crítica ao sujeito sartriano através de um busca pelo inconsciente das ações levou o estruturalismo a uma postura, nesse sentido, anti-humanista.

Quando Sartre, nos anos cinqüenta, se envolve com as concepções marxistas, o existencialismo foi, segundo Merquior, do historismo (a crença na lógica da história), para o historicismo (a crença na libertação através da história). Em contraste, novamente, Lévi-Strauss, marcou sua teoria com um antihistoricismo, ao estudar os povos primitivos não em busca das suas origens (o que teria apenas restituído a abordagem histórica), mas em busca de uma verdade sobre a humanidade fora da lógica historicista.

O estruturalismo se estabeleceu por um anti-humanismo e um anti- 
historicismo. Então, para o antropólogo, as três condições para que as ciências humanas atingissem a maturidade científica seriam: (a) seu objeto deve ser universal, ou seja, vigente em todas as sociedades conhecidas; (b) seu método deve ser sempre homogêneo, apesar da diversidade das áreas de aplicação; e (c) devem ter o consenso das autoridades sobre a validade dos pressupostos básicos subjacentes a seu método. Para Lévi-Strauss essas três características estavam bem representadas na linguística, que apresentou um objeto universal (a língua) e um método homogêneo (aplicável a todos os sistemas fonêmicos) abençoados por toda a comunidade científica relevante. E mais estritamente no método fonológico: analisava as relações entre termos ao invés de considerar os termos isoladamente; demonstrava, ao invés de simplesmente afirmar, o caráter sistêmico dos dados fonológicos; procurava regras gerais válidas para todos estes sistemas. Podemos ver esse visão de Lévi-Strauss sobre a linguística no seguinte trecho:

\begin{abstract}
"No conjunto das ciências sociais ao qual pertence indiscutivelmente, a linguística ocupa, entretanto, um lugar excepcional: ela não é uma ciência social como as outras, mas a que, de há muito, realizou os maiores progressos: a única, sem dúvida, que pode reivindicar o nome de ciência e que chegou, ao mesmo tempo, a formular um método positivo e a conhecer a natureza dos fatos submetidos à sua análise." (LÉVISTRAUSS, 2012a, p. 57)
\end{abstract}

Assim, através da linguística, o antropólogo inicia sua reflexão sobre a sua nova maneira de fazer antropologia. Muito influenciado pelos estudos do linguista suíço Ferdinand de Saussure (1857-1913), que dizia ser possível descobrir a estrutura permanente das línguas naturais sob sua miríade de manifestações reais: uma estrutura permanente composta de um número limitado de elementos e de uma soma, igualmente limitada, das suas combinações significativas. Nas palavras de Merquior:

\footnotetext{
"Afinal, só ele [Saussure] entrelaçou todas essas tramas do pensamento: a natureza não-motivada do signo verbal; a diferença entre significado e significante; o princípio da primazia da análise sincrônica; a necessidade de distinguir a estrutura, ou 'código', de uma determinada língua (langue) da imensa riqueza das suas infinitas mensagens, proferidas e ainda por proferir; e, por fim, o conceito de 'valor', que apontava para o fato de que a língua como um sistema operante repousa sobre uma complexa rede de oposições - oposições entre unidades bem como entre níveis de unidades inferiores e superiores (unidades inferiores como os fonemas, unidades superiores como os morfemas). Essas eram as principais ferramentas
} 
analíticas reunidas por Saussure sob seu pensamento fundamental: a injunção de se considerar a língua como um sistema." (MERQUIOR, 1991, p. 25)

Como pode-se observar, o equilíbrio delicado entre a forma e significado é o coração do programa estruturalista. Assim, para adentrarmos no estruturalismo no campo das ciências humanas, e mais propriamente na antropologia, precisamos perguntar juntamente com Merquior: "seria esse sutil jogo entre sistema e diferença capaz de produzir resultados semelhantes em outras esferas da cultura?" (MERQUIOR, 1991, p.26)

\title{
4.2
}

\section{A busca pelo universal}

A passagem, já citada aqui, de Mito e Significado, pode continuar nos situando no caminho que iremos percorrer no pensamento de Lévi-Strauss. Ela nos diz sobre a possibilidade de ordem no universo e no pensamento humano, possibilidade essa a que tentaremos explicar daqui em diante. Cito-a novamente:

\begin{abstract}
"Falar de regras e falar de significado é falar da mesma coisa; e, se olharmos para todas as realizações da Humanidade, seguindo os registros disponíveis em todo o mundo, verificaremos que o denominador comum é sempre a introdução de alguma espécie de ordem. Se isto representa uma necessidade básica de ordem na esfera da mente humana e se a mente humana, no fim de contas, não passa de uma parte do universo, então quiçá a necessidade exista porque há algum tipo de ordem no universo e o universo não é um caos.” (LÉVI-STRAUSS, 1985, p. 24)
\end{abstract}

Para poder afirmar que "quiçáa" o universo não é um caos, Lévi-Strauss se dedicou a estudos muito profundos e inovadores. Inspirado, portanto, no método da Lingüística, o antropólogo busca as estruturas invariantes dentro de uma enorme variedade de fenômenos, simbolizações, instituições e narrativas. Como noz diz Merquior:

"Na medida em que a antropologia estrutural pretende desenredar 'esquemas conceituais' ativos na vida social, e incorporados em instituições como parentesco ou produtos culturais como mitos, pode-se dizer que seu objetivo final é extrair universais humanos da realia, que são em si menos que universais e são, em geral, estudados segundo uma perspectiva da tota, ou seja, dos todos sociais aos quais pertencem." (MERQUIOR, 1991, p. 61) 
Quando, assim, Lévi-Strauss se dedica ao estudo do parentesco, como em As estruturas elementares do parentesco, de 1952; ou do totemismo (como em Totemismo Hoje e O Pensamento Selvagem); ou ainda se inclina a estudar os mitos, como no "The Golden Bough estruturalista" (MERQUIOR, 1991: 61), as Mitológicas, ele está preocupado com a classificação como uma propensão própria do pensamento humano, seja ele do presente ou do passado, "primitivo" ou moderno. Mesmo quando o antropólogo investiga uma enorme variedade de mitos regionais, como é o caso dos quatro volumes das Mitológicas e seus oitocentos mitos ameríndios esmiuçados, é fácil perceber que seu objetivo é demonstrar a aplicação ilimitada de alguns universais fundamentais da cultura, como aquele que considera fundamental: a antítese natureza-cultura simbolizada no "O cru e o cozido", primeiro volume da série. O estudo do simbolismo dentro da obra de Lévi-Strauss não se limita a compreender uma determinada área cultural, mas almeja alcançar as estruturas de uma espécie de pensamento universal. Seja nas Mitológicas, que trata especificamente de mitologia (fatos religiosos), ou no As estruturas elementares do parentesco, tratando das filiações e trocas (fatos sociológicos), a antropologia de Lévi-Strauss coloca sempre a mesma questão:

\footnotetext{
"[...] diante de um caos de práticas sociais ou de representações religiosas, continuaremos a procurar explicações parciais, diferentes para cada caso considerado? Ou tentaremos descobrir uma ordem abrangente, uma estrutura profunda através da qual possamos analisar essa diversidade aparente, em uma palavra, vencer a incoerência? Para domínios diferentes, As estruturas elementares e as Mitológicas levantarem o mesmo problema, e os métodos são idênticos." (apud. ERIBON, 2005, p. 199)
}

Essa "ordem abrangente" é encontrada, segundo Lévi-Strauss, tanto na mente humana, quanto na estrutura mesma da realidade. Para tanto, comecemos a olhar para análise do pensamento e do mito na teoria do antropólogo.

\section{3}

\section{"A etnologia é, primeiro, uma psicologia."}

Ao nos depararmos com a possibilidade de uma lógica e uma 
racionalidade inferidas ao homem por Lévi-Strauss, devemos, antes, encontrar nelas pontos de semelhança e diferença com as teorias clássicas, para que possamos melhor compreender as ideias do antropólogo.

Assim, o conceito de racionalidade, enquanto possibilidade de determinação da ordem e de relações necessárias entre as coisas (do discurso e da matéria), encontra, em Lévi-Strauss, aceitações e refutações. O estruturalismo levi-straussiano defende a possibilidade da manutenção do conceito de racionalidade, ao mesmo tempo em que nega a existência de uma única forma pela qual o pensamento representa o mundo e é capaz de constituir um discurso sobre como e porque as coisas são: há uma pluralidade de formas representativas. O antropólogo rompe com o "projeto clássico", ao conceber a pluralidade de formas articuladas contingentemente, mas, ao mesmo tempo, mantém sua filiação ao racionalismo clássico, ao defender a ideia de um pensamento concebido universalmente, pois este pensamento, para Lévi-Strauss, é regido por um único princípio racional: a classificação binária.

Portanto, se da tradição lógica clássica entendo, aqui, o projeto aristotélico e sua pretensão de determinar uma forma enunciativa única que desse conta da relação entre pensamento, discurso e mundo, ou seja, que desse conta da ordem inteira, Lévi-Strauss entra como aquele que irá rejeitar a possibilidade deste projeto que busca apenas uma lógica única. No estruturalismo do antropólogo, apresentado acima, as lógicas variam, mas a forma se mantém.

Ainda assim, ao pretender universalizar certa atividade do pensamento - a classificação binária - como condição de possibilidade da experiência, LéviStrauss não nega sua matriz kantiana. Ao se referir aos princípios de Kant que ficaram marcados na sua análise, o antropólogo diz: "Que o espírito tem suas limitações, que ele as impõe a um real para sempre impenetrável, e que só o compreende através dela" (ERIBON, 2005, p. 157). Ou seja, o binarismo, em Lévi-Strauss é a possibilidade mesmo de todo o conhecimento (aproximando-se assim do princípio de não-contradição aristotélico).

Mas, é preciso lembrar da famosa frase de Paul Ricouer, bem aceita por Lévi-Strauss: "o estruturalismo é um kantismo sem sujeito transcendental". No contexto kantiano, a experiência será objeto de um pensamento que conferirá a ela uma forma. Assim, em Lévi-Strauss, o pensamento reproduz e perpetua as classificações binárias sobre aquilo que é apreendido pela sensibilidade, ou seja, o 
pensamento emprega sua lógica binária na experiência. Mas, no pensamento do antropólogo não encontramos o "sujeito transcendental" de Kant. Esse sujeito pode ser definido através da seguinte explicação:

\begin{abstract}
"Sobre a unidade sintética da percepção (o sujeito transcendental) se assenta, segundo a arquitetônica kantiana, a possibilidade do entendimento (a faculdade de conhecer). Ela sintetiza as representações, pois é a unidade que reúne 'o diverso de uma intuição dada' (i.é. do múltiplo apreendido pela sensibilidade)." (CHAIMOVICH, 1992, p. 88)
\end{abstract}

Como podemos observar no trecho acima, em Kant, só há conhecimento na medida em que a unidade dos objetos deste conhecimento é conferida pelo próprio sujeito. Para além do campo desta experiência possível, nada mais se pode conhecer. Porém, no caso de Lévi-Strauss, o homem, para ele, não possui escolha quanto ao princípio binário: ele está inscrito no inconsciente humano. Assim, esse princípio é exterior ao sujeito, passivo frente à força de sua imposição. Donde se conclui que o sujeito kantiano do conhecimento, da qual a unidade sintética da percepção é a sua característica fundamental, não mais existe na teoria levistraussiana. Agora, o homem não possui mais escolha:

\footnotetext{
“o homem levistraussiano [...] está jogado para além da dúvida hamletiana [ser ou não-ser], pois não crê numa alternativa, restando-lhe apenas perpetuar a contradição" (CHAIMOVICH, 1992, p. 88).
}

A oposição, sob a forma de binarismo, em Lévi-Strauss, não possui apenas um sentido cognitivo, mas ontológico. O binarismo é uma característica do ser.

Desta forma, na realidade que o homem experiencia, segundo LéviStrauss, os dados imediatos da percepção sensível não são matéria bruta, nem cópia autêntica, mas consistem em propriedades distintivas, abstraídas do real por mecanismos de codificação e de decodificação inseridos no sistema nervoso e que funcionam por meio de oposições binárias. Mas, em "As duas naturezas de LéviStrauss", Philippe Descola faz com que nos perguntemos: os órgãos dos sentidos efetuam uma codificação dos estímulos por oposição de traços distintivos, ou se contentam em restituir uma codificação já presente na realidade exterior? Segundo Descola, Lévi-Strauss optou, sem hesitar, pela segunda opção quando afirmou que "o espírito realiza operações que não diferem por natureza daquelas que acontecem no mundo" (Cf. DESCOLA, 2011, p. 39). Juntamente dessa afirmação 
de Lévi-Strauss, poderíamos, como mais uma prova da teoria de Descola, lembrar a já tão citada aqui passagem do Mito e Significado, em que o antropólogo afirma que mente e universo possuem uma consubstancialidade (já que a mente é uma parte do universo). Assim, o espírito e a natureza realizam as mesmas operações. Se é possível captar alguma ordem no universo é porque deve existir mesmo uma ordem. Há, portanto, uma descontinuidade, nos dizeres de Lévi-Strauss, na própria estrutura da realidade. Ou seja, se é possível perceber alguma ordem, é porque ao experienciar o mundo, o homem não o experiencia como um contínuo fluxo desordenado, mas pode captar uma descontinuidade entre as coisas, agrupando-as de forma binária.

Ainda assim, a descontinuidade, para Lévi-Strauss é a possibilidade de qualquer pensamento. Lembrando Aristóteles, e seu princípio de não-contradição, ao que podemos afirmar que "uma coisa não é outra coisa, senão ela mesma", é a própria possibilidade de se construir um discurso inteligível e significativo:

\footnotetext{
"Se todos os homens estão igualmente certos e errados, ninguém pode dizer algo com sentido; pois então se deve dizer simultaneamente uma coisa e também a outra. E em respeito a que a condição de alguém que não diz nada, mas igualmente pensa e não pensa, difere de uma planta?" (ARISTÓTELES, 1987, p. $1008 b-15)$
}

Lévi-Strauss, portanto, assumindo o princípio de não-contradição, recoloca-o na escala humana ao afirmar que a codificação que faz o espírito é a mesma presente na natureza. $\mathrm{O}$ espírito capta o mundo pelo princípio binário, mas dá natureza também faz parte essa ordem, essa estrutura descontínua. Essa codificação é da ordem do ser, do ser da imanência.

Assim, nessa codificação binária, há uma predicação em, por exemplo, "P" e "Não-P". Mas, a originalidade do pensamento de Lévi-Strauss está em não admitir a existência de qualquer categoria predicativa a priori. Diferentemente de Aristóteles, para quem existem modos determinados a priori segundo os quais um predicado se aplica a um sujeito (classificando o sujeito, segundo o filósofo, por até dez modos), Lévi-Strauss não aceita esse predicação a priori, pois, ao se deparar com o estudo das sociedades "primitivas", afirma não existirem classificações necessárias, muito menos categorias necessárias. Nas sociedades tribais, "primitivas", não existem categorias a priori, nada é absolutamente de uma classe ou de outra nesse sentido. A classificação só pode ser empreendida por 
aquilo que o antropólogo chamou "lógica do concreto", que classifica a posteriori, através de uma interpretação binária da sensibilidade.

Lévi-Strauss dedicou uma longa análise a esse problema em duas de suas obras: Totemismo Hoje e O Pensamento Selvagem. Nessas obras (mais especificamente n'O Pensamento Selvagem), o antropólogo defende a lógica do pensamento "selvagem", o pensamento que ordena, classifica e significa as sociedades tribais. O "pensamento selvagem", segundo o pensador, não é o pensamento do selvagem, mas o pensamento em estado selvagem. Ou seja, ele possui tanta lógica quanto o pensamento clássico, expresso na filosofia ocidental. Porém, no "pensamento selvagem” não há uma separação, tão caracteristicamente ocidental, entre a ordem do sensível e a ordem do inteligível. Através dessa oposição, dessa ruptura, a ciência moderna pode constituir-se. Ela separou, nas palavras de Lévi-Strauss, as qualidades secundárias, ou seja, os dados sensíveis cores, odores, sabores, ruídos - das qualidades primárias, aquelas não tributárias aos sentidos, que constituem "a verdadeira realidade" (LÉVI-STRAUSS apud. ERIBON, 2005, p. 159). Assim, o "pensamento selvagem” é capaz de unir, pela sua "lógica do concreto", essas duas ordens separadas no pensamento ocidental, conduzindo a reflexão, portanto, no plano das qualidades sensíveis, passando a gerar, sobre essa base, uma visão de mundo que não é desprovida de coerência nem de lógica.

A "lógica do concreto" opera através da interpretação binária da sensibilidade, ordenando a realidade através de sistemas cuja "necessidade" interna advém de categorias empíricas. Assim, por exemplo, se estrutura o mito.

\section{4}

\section{Mito e significado}

Descola, afirmando que Lévi-Strauss recusou a oposição entre matéria e espírito, demonstra o que chamou de "as duas naturezas de Lévi-Strauss":

“[...] um, de tipo tecnoeconômico, impõe ao pensamento coerções resultantes da relação que a sociedade mantém com um meio particular; o outro reflete as exigências inerentes ao funcionamento do espírito e se manifesta sempre idêntico, 
independentemente das diferenças entre os meios.”(DESCOLA, 2011, p. 37)

A primeira natureza é aquele em que o homem se serve através propriedades objetivas dos objetos naturais. $\mathrm{O}$ espírito seleciona, em determinado contexto cultural, uma série de elementos para depois encaixá-los em conjuntos significantes, como os mitos e as taxonomias. Assim, para o antropólogo, é importante conhecer bem a ecologia de uma sociedade se há a intenção de analisar suas produções ideológicas, pois elas são a prova de um compromisso entre certos traços do meio e as leis que organizam o pensamento simbólico.

Essa natureza enciclopédica, a que o pensamento se apropria para suas simbolizações, é “boa para pensar". Mas, essa natureza que está à disposição do espírito humano se opõe àquela outra, tão citada por Lévi-Strauss, a que expusemos acima: a natureza orgânica da nossa espécie. É por meio dessa natureza que, segundo Lévi-Strauss, efetuamos a percepção e a intelecção dos objetos sensíveis, ela é o mecanismo biológico que garante a unidade das operações mentais e "autoriza a esperança de decifrar-lhes as regras" (DESCOLA, 2011: 38). Ao passo que há uma natureza colocada num papel subsidiário, há uma outra com um lugar privilegiado. Como na passagem citada de Mito e Significado, a teoria das faculdades lévi-straussiana se recusa a separar os estados da subjetividade, das propriedades do cosmos. Assim,

"[...] as leis do pensamento são as mesmas que se exprimem na realidade física e na realidade social, não sendo esta última outra coisa que um dos seus aspectos" (LÉVI-STRAUSS, 1982, p. 520).

Portanto, há uma base da natureza a que o indivíduo se utiliza nas suas construções simbólicas, mas essas construções obedecem leis do pensamento que são as mesmas que se exprimem na realidade física e social.

Em $O$ pensamento selvagem, porém, Lévi-Strauss ressalta o aspecto arbitrário que comanda as escolhas dos traços distintivos atribuídos a tal ou qual componente dos ecossistemas locais. Nas palavras de Descola:

“[...]Lévi-Strauss insistia em mostrar que não há nada de automático nem de previsível no modo como uma sociedade seleciona este ou aquele aspecto de seu hábitat para atribuir-lhe um significado particular e integrá-lo em suas construções míticas.” (DESCOLA, 2011, p. 38) 
Essa arbitrariedade, no entanto, segundo Lévi-Strauss, é compensada pela organização dos elementos em sistemas coerentes. A estrutura dos mitos, portanto, não é aleatória, mas se organiza dentro de determinado número de regras. Essas regras se estruturam por aquela lógica explicamos acima, a "lógica do concreto". O antropólogo, assim, recorre a figura do bricoleur, o artista que compõe sua obra deslocando elementos do seu universo original (fazendo mesmo uma colagem de diversos objetos de diferentes "lugares"). A narrativa mítica se assemelha ao trabalho do bricoleur por reunir elementos diversos dentro de uma ordem e de uma lógica coerentes:

\footnotetext{
“Ora, a característica do pensamento mítico é a expressão auxiliada por um repertório cuja composição é heteróclita e que, mesmo sendo extenso, permanece limitado; entretanto, é necessário que o utilize, qualquer que seja a tarefa proposta, pois nada mais tem à mão. Ele se apresenta, assim, como uma espécie de bricolage intelectual, o que explica as relações que se observam entre ambos." (LÉVI-STRAUSS, 2012, p. 33)
}

$\mathrm{Da}$ "natureza enciclopédica", esse bricoleur retira os elementos que irão simbolizar e significar dentro da estrutura do mito. Esses elementos, como vimos, são trabalhados de forma binária, reconhecidos pela característica de descontinuidade do fluxo da realidade.

O pensamento mítico, confrontado por um problema particular, coloca-o em paralelo com outros. Um mito, diz Lévi-Strauss, jamais tratará de um problema relevante em si e por si mesmo. Ele se empenhará em mostrar que esse problema é formalmente análogo a outros problemas que os homens possuem a respeito, por exemplo, dos corpos celestes, da alternância do dia e da noite, da sucessão das estações, da organização social, das relações políticas entre os grupos vizinhos.

O mito, como sabemos, ordena o mundo e também legitima essa ordem. Como Lévi-Strauss afirmou acima, há uma "homologia dos domínios", ou seja, para o pensamento mítico a ordem estabelecida é toda ela uma ordem só, o distúrbio de uma de suas partes será o fim da ordem como um todo. Perguntado sobre para que serve o mito, Lévi Strauss responde: 
"Para explicar por que, diferentes de início, as coisas se transformam no que são, e por que elas não podem ser de outra maneira justamente porque, se mudarem num domínio particular, toda a ordem do mundo seria perturbada, devido à homologia dos domínios" (ERIBON, 2005, p. 198)

Portanto, o "pensamento selvagem" se estrutura através da uma explicação total. A "homologia dos domínios" exige do mito uma "ambição totalitária" (LÉVI-STRAUSS, 1985: 31), uma maneira de pensar e explicar as coisas que parte do princípio de que, se não se compreende tudo, não se pode explicar coisa alguma. Essa maneira de pensar é bem diferente do pensamento científico, mas, para o antropólogo, ela também age por meios intelectuais, tanto quanto um cientista moderno. Enquanto o pensamento científico, herdeiro de Descartes, divide a dificuldade em tantas partes quantas as necessárias para resolvê-la, o "pensamento selvagem" explica todas as partes através da crença numa ordem única, não sendo por isso menos "intelectualizada":

\begin{abstract}
"O que tentei mostra, por exemplo, em Totemisme ou La Penseé Sauvage, é que esses povos que consideramos estarem totalmente dominados pela necessidade de não morrerem de fome, de se manterem num nível mínimo de subsistência, em condições materiais muito duras, são perfeitamente capazes de pensamento desinteressado; ou seja, são movidos por uma necessidade ou um desejo de compreender o mundo que os envolve, a sua natureza e a sociedade em que vivem. Por outro lado, para atingirem este objectivo, agem por meios intelectuais, exactamente como faz um filósofo ou até, em certa medida, como pode fazer e fará um cientista." (LÉVI-STRAUSS, 1985, p. 30)
\end{abstract}

O "pensamento desinteressado", admitido estar presente tanto presente no mito quanto na ciência, faz Lévi-Strauss retirar um status de inferioridade, que tantos anos foi imposto, no tipo de racionalidade dos "povos sem escrita". Todos os homens estruturam seu pensamento da mesma forma, o que não implica em dizer que todos os homens, para Lévi-Strauss, conseguem alcançar o mesmo tipo de domínio sobre a natureza, como fez a ciência moderna.

Para que possamos ver como opera essa mentalidade na formação de um mito, ilustraremos, aqui, esse processo através de mito do Canadá Ocidental, tratado por Lévi-Strauss em Mito e Significado, sobre uma raia que tentou controlar ou dominar o Vento Sul e obteve êxito na empresa. O mito narrado por Lévi-Strauss, é ambientado, como grande parte deles, em uma época anterior à existência do homem na Terra, ou seja, de um tempo em que os homens não se diferenciavam dos animais; esses seres eram meio humano e meio animais. Como 
ventava o tempo todo, todos se sentiam muito incomodados, pois isso impedia com que eles pescassem ou que procurassem conchas com moluscos na praia. Assim, esses animais humanizados ou humanos animalizadaos, resolveram lutar contra os ventos, obrigando-os a comportarem-se mais decentemente. Então, organizaram uma expedição para este feito, e a raia desempenhou um importante papel na captura do Vento Sul. Este só foi libertado depois de prometer que não voltaria a soprar constantemente, mas só de vez em quando, ou só em determinados períodos. Desde então, o Vento Sul só sopra em certos períodos do ano ou, então, uma única vez a cada dois dias, fazendo com que a humanidade (simbolizada pela sociedade produtora do mito) possa se dedicar às suas atividades.

Lévi-Strauss, assim, ao invés de taxar a história de absurda, fruto de uma mente delirante, leva-a a sério, como todo o estudioso de mitologia precisa fazer, e faz a seguinte pergunta: porquê a raia e porquê o Vento Sul?

Ao se estudar minuciosamente o mito, diz o antropólogo, pode-se perceber que que a raia atua com base em determinadas características, que são de duas espécies. A primeira delas, é que a raia, como peixe, possui a característica de ser escorregadia por baixo e dura por cima. E a outra característica, que permite à raia escapar com sucesso quando tem de enfrentar outros animais, é que ela parece ser muito grande quando vista de cima ou de baixo, mas é extremamente delgada quando vista de lado.

\begin{abstract}
"Um adversário poderia pensar que seria muito fácil disparar uma seta e matar uma raia, por ela ser tão grande; mas, enquanto a seta se dirige para o alvo, a raia pode virar-se ou deslizar rapidamente oferecendo apenas o perfil, que , evidentemente, é impossível de atingir; e é assim que pode escapar." (LÉVISTRAUSS, 1985, p. 36)
\end{abstract}

Parece que foi assim, através dessa estratégia, que a raia conseguiu aprisionar o Vento Sul. A raia, portanto, foi escolhida para ocupar esse lugar no mito porque, para Lévi-Strauss, ela é um animal capaz de responder empregando uma linguagem da cibernética (a linguagem binária do "um" e "zero") - em termos de "sim" e "não"; é capaz de dois estados descontínuos: um positivo e outro negativo. Se de um ponto de vista empírico, um peixe não pode lutar contra o vento, sob um ponto de vista lógico, segundo o antropólogo, a raia é 
usada como um operador binária para resolver um problema binário. Se o Vento sul sopra todos os dias do ano, a vida passa a ser impossível para a humanidade. Mas, se apenas soprar um em cada dói dias, ou seja, "sim" num dia e "não" no outro, gera-se um equilíbrio entre as necessidades da humanidade e as condições predominantes do mundo natural.

Encontramos nesse mito algumas características fundamentais, segundo Lévi-Strauss: o problema da passagem da natureza para a cultura simbolizado pelo Vento Sul (natureza) e seu aprisionamento para que a humanidade possa se viver e construir seus agrupamentos e culturas; e a razão pela qual se utilizam imagens retiradas da experiência, no caso a raia.

Sobre essa segunda característica, a imagem da raia é utilizada, como dito, como um operador binário para um problema binário. Suas características de fato, ou seja, seus dois estados descontínuos (escorregadia e dura; muito grande e extremamente delgada), dão a ela a situação de ser um operador binário, respondendo "sim" ou "não", assim como o problema que ela resolve: o Vento Sul precisa funcionar em termos de "sim" (soprar) e "não" (não soprar) para que a vida possa ser possível para a humanidade.

Isso vem colocar a questão de que, para Lévi-Strauss, a materialidade dos elementos que compõem o mito é significativa. Como, para o pensador, no pensamento selvagem inexistem categorias a priori, a explicação da história da raia e do Vento Sul é um bom começo para entendermos a escolha de certos elementos em detrimento de outros nas sistematizações fundadas em categorias $a$ posteriori, como é o caso do mito. Colocando em uma questão o problema: por que razão um elemento é escolhido como representativo de um conjunto de relações? Rejeitando as teorias funcionalistas e suas explicações que colocam a razão da escolha nas funções desempenhadas empiricamente pelos elementos, Lévi-Strauss coloca a escolha de determinados elementos na estrutura "lógica" local e não na sua materialidade imediata. Assim, a escolha dos elementos depende da maior ou menor disposição daqueles à aplicação da matriz binária. $\mathrm{Ou}$ seja, a escolha da raia está explicada pela sua capacidade de figurar logicamente como operador binário para resolver um problema de lógica binária (o "soprar" ou “não-soprar" do Vento Sul), e não na materialidade imediata da raia ou na função que ela desempenha empiricamente. Como nos explica Chaimovich: 
"A metáfora levistraussiana do pensamento como 'bricolage' confere às categorias a posteriori um limite empírico residual, ainda que os elementos utilizados estejam deslocados do seu universo original. O bricoleur dispõe de peças que serão utilizadas para fins diferentes daqueles para os quais foram originalmente concebidas. Se esse personagem tem à mão alguns fios elétricos cuja área de secção transversal é de, digamos, $2.5 \mathrm{~mm}^{2}$, poderá improvisar um varal amarrando as extremidades dos fios em seu páteo. Este deslocamento da utilidade original implica numa criação de sentido, pois não fazia parte do universo original do fio o servir de varal. Entretanto, se o fio não fosse suficientemente comprido e com tal secção de área (se fosse, p. ex., muito grosso), não seria uma possibilidade empírica nele inscrita poder servir de varal. Neste caso, não há uma total contingência na categorização a posteriori: há uma gramática dos elementos da experiência que não permite que um fio de $50 \mathrm{~mm}^{2} \mathrm{de}$ secção sirva de varal. Portanto, a máquina de ordenar binariamente tem que respeitar certos limites dos elementos disponíveis à sua sensibilidade. Assim, antes da oposição classificadora, subsistiria uma natureza real." (CHAIMOVICH, 1992, p. 91)

Ao descolar os elementos, há uma gramática dos elementos da experiência a que essa máquina de ordenar binariamente tem que respeitar. Essa gramática impõe certos limites, uma natureza real. Há, portanto, uma descontinuidade (ordem) na natureza; os elementos naturais têm, de fato, diferenças entre si: há “espécies naturais". Embora Lévi-Strauss não aceite a existência de categorias lógicas a priori, admite a existência de espécies naturais que obrigam o pensamento a se adequar a uma "codificação objetiva" (LÉVI-STRAUSS, 2012, p. 157$)^{16}$.

Portanto, do mito participam elementos pelos quais o próprio mito se utiliza para explicar realidades de ordem lógica. O "pensamento selvagem" pela sua sanha de explicar de maneira totalizante, elenca elementos da ordem natural para figurarem no mito, e como um bricoleur reagrupa esses elementos numa ordem lógica para explicar realidades. Como nos diz Lévi-Strauss:

"[...] as relações do homem com o meio natural desempenham o papel de objetos de pensamento; o homem não as percebe passivamente, ele as tritura depois de têlas reduzido a conceitos, para deles inferir um sistema que nunca é predeterminado: supondo-se que a situação seja a mesma, ela sempre se presta a várias sistematizações possíveis. O erro de Mannhardt e da escola naturalista foi acreditar que os fenômenos naturais são o que os mitos procuram explicar, enquanto são mais aquilo por meio de que os mitos tentam explicar realidades, elas mesmas de ordem não natural, mas lógica.” (LÉVI-STRAUSS, 2012, p. 113)

\footnotetext{
${ }^{16}$ Sobre assunto também ver: "Pósfácio aos capítulos III e IV" no clássico de Lévi Strauss Antropologia estrutural.
} 
Esse ponto resolve a pergunta que Lévi-Strauss postulou no seu célebre artigo "A estrutura dos mitos": “[...] se o conteúdo do mito é inteiramente contingente, como explicar que, de um extremo a outra da Terra, os mitos se pareçam tanto?” (LÉVI-STRAUSS, 2008, p. 295). As realidades que o mito se propõe a resolver são de ordem lógica, da ordem do pensamento.

Assim, nesse conhecido artigo, Lévi-Strauss estabelece regras para a interpretação dos mitos. Para tanto, primeiro, deve-se perceber que no simbolismo complexo do mito, cada unidade simbólico, chamado pelo antropólogo de "mitema" (de acordo com a analogia com os elementos da lingüística, "fonema" e "morfema") nunca carrega em si significado. Como as unidades constitutivas da língua, os mitemas só adquire significado mediante sua oposição a outras unidades. Em segundo lugar, estas mesmas oposições podem pertencer a vários domínios da realidade: ao mundo natural, a relações sociais, a costumes culinários e etc (nenhum desses domínios, na antropologia estrutural, possui privilégio ontológico). Em terceiro lugar, as oposições também podem desdobrar-se em outras antíteses, bem como ser invertidas entre si. Ainda se pode dizer que, para Lévi-Strauss, cada mito deve ser visto como uma variação sobre o mesmo tema:

\footnotetext{
"Pelo menos variações sobre um grande tema: a passagem da natureza à cultura que foi preciso pagar com a ruptura definitiva da comunicação entre o mundo celeste e o mundo terrestre. Daí, para a humanidade, alguns problemas em torno dos quais gira essa mitologia." (ERIBON, 2005, p. 193)
}

Outro exemplo de mito interpretado por Lévi-Strauss, mas agora em "A estrutura dos mitos", foi o mito tebano de Édipo. Ele segmentou o mito em "feixes de relações" referentes às relações entre os personagens. Assim, cada "feixe de relações" continha mitemas que versavam sobre o mesmo tema. Ele formou, assim, quatro colunas: (a) a primeira reúne elementos como laço incestuoso de Édipo com sua mãe Jocasta e o amor de Antígona pelo irmão Polinice; (b) a segunda reúne a relação entre Édipo e o pai Laio e a luta entre os irmãos Etéocles e Polinice; (c) a terceira inclui a matança do dragão por Cadmo, fundador de Tebas, bem como o triunfo de Édipo sobre a Esfinge; (d) o último "feixe de relações" registra detalhes anedóticos como os defeitos físicos de Laio e Édipo, ambos do lado esquerdo.

Em seguida, interpretando essas colunas, Lévi-Strauss mostra que a 
primeira é o exato oposto da segunda coluna, no sentido que se pode dizer o denominador comum de (a) é uma superestima dos laços de sangue, ao passo que o denominador comun de (b) repousa numa subestimação dos laços de sangue, simbolizado no parricídio de Édipo e no fatricídio de Etéocles. Da mesma forma, o antropólogo afirma que as colunas (c) e (d) estão em oposição. Enquanto (c) refere-se a monstros (o Dragão, e a Esfinge), a coluna (d) é ocupada por homens que são, pelos seus defeitos físicos, de alguma forma monstruosos.

É preciso elucidar melhor as colunas (c) e (d). No mito grego, quando Cadmo matou o dragão (mitema contido na coluna c), ele plantou o dente do monstro e fez, conseqüentemente, nascerem homens denominados "ctônicos" (aqueles nascem da terra). A Esfinge é o monstro que também nas ce da própria terra e se empenha em tirar a vida de suas vítimas humanas. Como os dois monstros são definitivamente vencidos pelos homens, para Lévi-Strauss, essa coluna se refere a "negação da autoctonia humana" (LÉVI-STRAUSS, 2008, p. 307). Já em relação a coluna (d) é preciso dizer que o defeito físico de Édipo eram pés aleijados que dificultavam seu andar. Como, "[e]m mitologia, os homens, nascidos da terra, são com frequiência representados, no momento de sua emergência, como ainda incapazes de andar, ou andando desajeitadamente" (LÉVI-STRAUSS, 2008: 308), a quarta coluna refere-se a "persistência da autoctonia humana" (LÉVI-STRAUSS, 2008, p. 308). Assim, pode-se ver a oposição entre as colunas (c) e (d).

De acordo com Lévi-Strauss, o mistério subjacente á história de Édipo é que a religião grega sustentava a "autoctonia" do homem e, logicamente, teve de enquadrar tal crença à verdade empírica de que os humanos nascem de mulheres e não da terra:

\footnotetext{
"Ele exprimiria a impossibilidade na qual se encontra uma sociedade que professa acreditar na autoctonia do homem (cf. Pausânias, VIII, XXIX, 4: 'o vegetal é o modelo do homem') de passar dessa teoria para o reconhecimento do fato de que cada um de nós na verdade nasceu da união de um homem e de uma mulher." (LÉVI-STRAUSS, 2008, p. 309)
}

O papel conceitual do mito consistiria, então, em servir como um “instrumento lógico” (LÉVI-STRAUSS, 2008, p. 309) para “mediar” as oposições acima, para "superar" ou pelo menos "substituir" as contradições agudas na psique social: “[...] o pensamento mítico provém da tomada de consciência de 
determinadas oposições e tende à sua mediação progressiva" (LÉVI-STRAUSS, 2008, p. 321). O problema do mito do Édipo de que os humanos nascem de mulheres e não da terra se relaciona, então, com uma questão derivativa: o mesmo nasce do mesmo ou do outro? Não sendo, então, possível superar essas contradições, o mito tenta mediá-las através de seu aparato simbólico, ele não nos oferece nenhuma sabedoria última:

"De forma alguma um sábio junguiano, Lévi-Strauss não pensa nos mitos como arcanos. No seu Mythologiques, embarcamos em longas jornadas de interpretações, testemunhando permutações infindáveis entre cadeias de oposições - mas não terminamos mais sábios por isso, nem há razão alguma para pensarmos que foi diferente com a mente primitiva [...] [No mito lévistraussiano] as maravilhas do intelecto não são, de forma alguma, um caminho para a Verdade." (MERQUIOR, 1991, p. 78)

"As maravilhas do intelecto", como vimos nesse capítulo, para LéviStrauss são iguais em todos os homens: “[...] a mente humana, apesar das diferenças culturais entre as diversas fracções da Humanidade, é em toda a parte uma e mesma coisa" (LÉVI-STRAUSS, 1985, p. 33). Porém, esse intelecto, através do mito, "dá a ilusão ao homem de que ele pode entender o universo e de que ele entende, de facto, o universo. Como é evidente trata-se apenas de uma ilusão" (LÉVI-STRAUSS, 1985, p. 32). Como o antropólogo já havia dito na Introdução que fez ao Sociologia e Antropologia de Mauss, no momento em que o universo ficou mais significativo, ele não tornou-se, por isso, mais conhecido.

Os homens significam o seu mundo através de seu pensamento. Pensamento, esse, que possui uma forma, uma maneira igual de pensar: o dualismo. O mito, assim, ordena o mundo dos homens, mas não o deixa mais conhecido. Ele media as oposições, tentando estabilizá-las, tenta resolver as dualidades fundamentais entre cultura e natureza (como no mito da raia) ou entre autoctonia ou não do homem (como no mito do Édipo). São resposta fundamentais sobre a vida do homem, respectivamente, sobre a possibilidade da sua existência e sobre a origem da sua vida. 


\section{5.}

\section{Conclusão}

Ao final desse trabalho é difícil não reconhecer que Voegelin e LéviStrauss são dois pensadores de peso. Suas teorias, por mais contestadas ou dificilmente assimiladas, possuem características únicas e inovadoras.

Podemos reconhecer algumas semelhanças nos pensamentos desses intelectuais. Tanto Voegelin quanto Lévi-Strauss não fazem do pensamento mítico, do "pensamento selvagem", da mentalidade cosmológica, sinal de ignorância e atraso. Voegelin diz que o mito é a simbolização de maneira compacta de um homem que experiencia o cosmos como algo sagrado, explicando-lhe o Todo. Lévi-Strauss caracteriza o "pensamento selvagem" como aquele que pretende dar um significado total para seu universo através da organização de elementos em uma lógica que não é diferente da do cientista moderno.

Nas sociedades cosmológicas, as do pensamento mítico, há uma fusão do nomos (a ordem socialmente estabelecida) com o cosmos (tudo aquilo que é considerado como os sentidos fundamentais inerentes ao universo). Assim, a religião, que dá o caráter sagrado do cosmos, é a maneira mais eficiente de se obter êxito na socialização porque ela permite um significado forte e total na vida do indivíduo bem como na estrutura da sociedade. Numa ordenação social assim, nomos e cosmos aparecem como co-extensivos; a ordem aparece como "coisa óbvia", atinge o status de ser algo que não pode ser mudado. Como Lévi-Strauss disse sobre a função do mito, que é a função da ordem:

"Para explicar por que, diferentes de início, as coisas se transformam no que são, e por que elas não podem ser de outra maneira justamente porque, se mudarem num domínio particular, toda a ordem do mundo seria perturbada, devido à homologia dos domínios" (ERIBON, 2005, p. 198)

A ordem mantém, portanto, o meio social unido de forma coerente, impedindo que seus estratos entrem em estado de anomia. A "construção do 
mundo" nas sociedades cosmológicas é algo a que os indivíduos estão alienados. E alienação, como nos lembra Berger, não é anomia:

\begin{abstract}
"A consciência primitiva e infantil apreende o mundo sociocultural em termos essencialmente alienados, como facticidade, necessidade, sina. Só muito depois na história ou na biografia de indivíduos vivendo em circunstância históricas específicas, é que surge a possibilidade de se compreender o mundo sociocultural como um empreendimento humano. Em outras palavras, a apreensão do mundo sociocultural como um opus alienum sempre precede sua apreensão como opus proprium do homem. Em terceiro lugar, a alienação é um fenônemo completamente diferente da anomia. Pelo contrário, a apreensão alienada do mundo sociocultural serve para manter suas estruturas nômicas particularmente eficazes, justamente porque aparentemente as imuniza contra as inumeráveis contingências de tarefa humana de construção do mundo." (BERGER, 2012, p. 98)
\end{abstract}

A consciência "primitiva", o pensamento mítico, se aliena da possibilidade de construir o mundo porque quer nele captar seu significado. Do ponto de vista sociólogo é óbvio que assim fazendo, o homem das sociedades cosmológicas acaba produzindo a sua ordem. É a concepção de religião de Feuerbach que impregnou as Ciências Sociais: os sentidos da ordem humanamente construída, na religião, são projetados no universo como tal.

Mas, como já foi possível perceber, Voegelin e Lévi-Strauss complexificam um pouco mais esse debate sobre a ordem. Para que possamos reconhecer mais diferenças e semelhanças do pensamento de ambos os intelectuais, recorro aqui ao estudo do simbolismo da cruz. A leitura do material mais relevante sobre religiões comparadas, principalmente na figura do metafísico francês René Guénon, me ajudou a conceber essa ideia. No seu Le simbolisme de la croix, Guénon demonstra como o símbolo da cruz permeia os mais diferentes povos nas suas simbolizações sagradas. Assim, não me atenho aqui ao símbolo da cruz como expresso na sua hoje mais reconhecida expressão: o símbolo cristão da cruz de Jesus Cristo. Abaixo, demonstro, através de um pequeno esquema, como podemos compreender o simbolismo universal da cruz: 


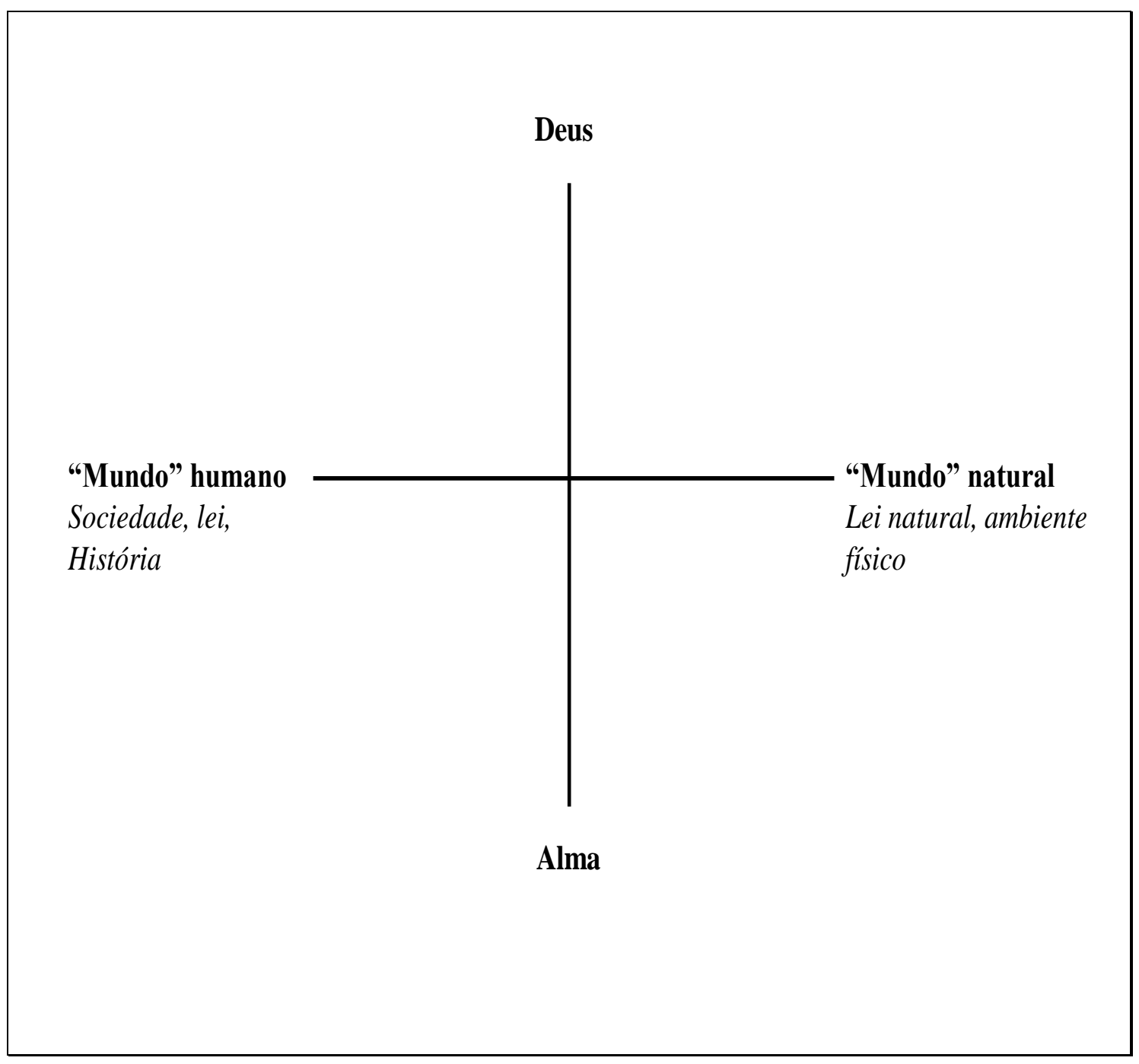

Como é possível perceber, o eixo vertical se refere à relação homem-Deus, ou ideia da imanência e da transcendência. $O$ eixo horizontal se refere especificamente aos pólos da imanência: a natureza e a sociedade e suas descendências.

Como vimos no Capítulo II, a realidade, aquela com " $\mathrm{R}$ ” maiúsculo, para Voegelin se compõe de todos os pólos apresentados no esquema acima. Assim, homem e Deus, mundo e sociedade, que, para ele, formam a "comunidade primordial do ser”, são partes integrantes da realidade. Essa realidade se estrutura através da metaxy, ou seja, da tensão ou equilíbrio entre os quatro pólos. O homem experiencia essa realidade como um "Intermédio". Sua consciência, que está no fluxo da realidade, é o palco das experiências de participação na realidade. O centro da consciência está na experiência de participação, na realidade do 
contato do homem com a realidade que está fora dele. A experiência é o que está entre o sujeito e o objeto da participação. Portanto, ela não está nem no sujeito nem no mundo dos objetos, mas no que Voegelin chamou de "Intermédio", ou metaxy, isto é o pólo entre o homem e a realidade que ele experiência. Como a fonte da ordem, para Voegelin, se encontra na transcendência, é preciso se sintonizar com essa fonte para que a ordem correta do homem e da sociedade possa ser obtida. Assim, da realidade do homem participa a realidade da presença divina:

"O caráter de Intermédio da experiência revela-se particularmente importante
para compreender as reações humanas aos movimentos da presença divina.
Porque a experiência desses movimentos não está, justamente, situada no fluxo de
consciência do homem - homem entendido no sentido imanentista -, mas no
Intermédio entre o divino e o humano. A experiência é a realidade de ambas as
presenças, humana e divina, e só depois de acontecer é que ela pode ser atribuída
seja à consciência do homem, seja ao contexto da divindade com o nome de
revelação." (VOEGELIN, 2008, p. 115)

Assim, separar esses pólos da experiência, para o filósofo, implica num descarrilamento (deraiment) da razão. Não se pode hipostasiar esses dois pólos da experiência, sob pena de falsear a realidade. A condição humana é a existência no In-Between, no Intermédio, na metaxy, da imanência e da transcendência, da mortalidade e da imortalidade, da natureza e da cultura. É preciso reconhecer todos os níveis da realidade que o homem experiencia. O homem de Voegelin se encontra no centro da cruz, como participante de todas essas realidades.

Portanto, se olharmos com os olhos de Voegelin para a teoria de LéviStrauss iremos encontrar muitas diferenças. Inicialmente, através do simbolismo da cruz, podemos dizer que, para o antropólogo, a realidade só se compõe do eixo horizontal da cruz. Pela sua herança kantiana, a impossibilidade de se conhecer a realidade ou a coisa-em-si, impede, portanto, a possibilidade se saber se Deus existe ou não. A transcendência está longe de ser um fato para Lévi-Strauss; ele mesmo abandonou seus estudos filosóficos ainda jovem para se afastar de elucubrações desse tipo. Fazer ciência, segundo o pensador, é não se sujeitar à metafísicas e, no fundo, é ser um estruturalista: "Las sciences l'homme seront structuralistes ou bien elles ne seront pas".

Essa prepotência de Lévi-Strauss, justificável pelo menos na época, foi vista por Voegelin como algo pernicioso em seu artigo "Structures of 
consciouness". Além disso, aquilo que o filósofo disse de Husserl poderia ser dito, por ele, de Lévi-Strauss:

"O estudo de Husserl me interessou muito por causa de seu magnífico apanhado da história, que vai de Descartes à sua própria obra. Por outro lado, era enervante a presunção ingênua de um filósofo de que acreditava, com seu método fenomenológico, ter aberto o que chamava de horizonte apodíctico da filosofia. Para Husserl de agora em diante, quem quisesse tornar-se um filósofo competente deveria ser seu discípulo." (VOEGELIN, 2008, p. 110)

Lévi-Strauss, ao dizer que ou bem a ciência seria estruturalista ou ela não seria nada, abre espaço para esse tipo de crítica. Uma ciência estruturalista é uma ciência baseada, entre outros preceitos, num materialismo, ou como chamei na "Introdução", um materialismo hard. Assim, Lévi-Strauss desconsidera a esfera transcendente e, na visão de Voegelin, hispostasia o eixo imanente da realidade, gerando um derailment da razão.

O homem, para Voegelin, é constituído de noûs e pneuma: respectivamente, a esfera da razão, como simbolizada pelos clássicos gregos, a esfera do espírito, aquela que Deus dirige a sua palavra. O homem, portanto, está aberta ao Logos divino. Aquele que se opõe a essa maneira de ver o homem, aquele que "tapa" a esfera da transcendência, é visto por Voegelin como um gnóstico. Não pretendo entrar nos pormenores dessa análise, mas o gnóstico, no sentido voegeliniano, é aquele que fecha a sua alma para a presença divina. No fundo, é o que retira o eixo transcendência-imanência da realidade. Essa característica é, para Voegelin, a característica fundamental da era moderna.

Lévi-Strauss, como um cientista moderno, poderia ser considerado por Voegelin como um gnóstico. A realidade, para o antropólogo, se resume na imanência e sua característica de descontinuidade que agrupa elementos, através do homem, de forma binária.

A ausência do eixo vertical, como vista na ontologia de Lévi-Strauss, não mais permite uma desigualdade tão flagrante como aquela que existe entre Deus e o homem. Assim, pela lógica do simbolismo da cruz, cada pólo do eixo horizontal tentará eternamente tomar o lugar de Deus, numa luta sem fim. Uma hora a história será alçada ao patamar de significado último (como no historicismo de Marx), outra hora serão as leis da natureza (como no determinismo biológico), e outra vez ainda será o ambiente físico (como no determinismo geográfico). Ainda 
podem ser vistos muitos outros exemplos, mas o que importa aqui é perceber como estou tentando me utilizar do simbolismo da cruz.

O homem levi-straussiano está no centro do eixo horizontal, entre a natureza e a cultura. Ao contrário de outras teorias, Lévi-Strauss tenta deixar esse eixo equilibrado, mesmo que às vezes pareça tentar colocar a natureza em um patamar mais elevado. Nessa gangorra de difícil equilíbrio, o homem se encontra entre as suas duas naturezas: a primeira natureza é aquela em que o homem se serve através propriedades objetivas dos objetos naturais. $\mathrm{O}$ espírito seleciona, em determinado contexto cultural, uma série de elementos para depois encaixá-los em conjuntos significantes, como os mitos e as taxonomias. Mas, como vimos, esse espírito é compelido por outra natureza, a natureza orgânica da nossa espécie, que efetua a percepção e a intelecção dos objetos sensíveis.

Essa natureza é feita de um racionalismo de tipo binário. Esse esquema do simbolismo da cruz também nos ajuda a elucidar esse ponto. Como disse Ricouer, "o estruturalismo é um kantismo sem o sujeito transcendental". Assim, o binarismo se coloca como a única condição de pensamento nesse caso. Excetuando-se o eixo vertical da transcendência, o que resta é a replicação $a d$ infinitum dos dois pólos no processo binário de pensamento.

O mito, para Lévi-Strauss, é o exemplo de como o pensamento humano funciona igual em toda a parte: ele se estrutura através de um binarismo. Os homens significam o seu mundo através de seu pensamento. Pensamento, esse, que possui uma forma, uma maneira igual de pensar: o dualismo. O mito, assim, ordena o mundo dos homens, mas não o deixa mais conhecido. Ele media as oposições, tentando estabilizá-las, tenta resolver as dualidades fundamentais como cultura e natureza.

Já em Voegelin, podemos ver que o mito é a representação simbólica de uma consciência que procura intencionalmente (consciência essa que Lévi-Strauss rejeita por completo) responder perguntas fundamentais como a origem da vida. $\mathrm{Na}$ articulação compacta do mito, segundo Voegelin, existem muitas respostas importantes. Como Aristóteles, que disse que o philomythos é um philosophos, Voegelin reconhece que todo o mito possui a sua verdade. Como o mito é a simbolização da estrutura quaternária da realidade, assim como ela é entendida por Voegelin (homem e Deus, mundo e sociedade), o mito possui uma verdade feita de maneira compacta da qual, posteriormente, simbolizações como o mito 
grego, a Torá ou o cristianismo articularão de maneira diferenciada (como vimos nas relações entre o mito de Adapa e o mito de Adão):

"A virtude do mito cosmogônico, por outro lado, está em sua compacidade: ele se origina num entendimento integral da ordem do ser, fornece os símbolos que expressam adequadamente uma multiplicidade balanceada das experiências e é uma força viva que preserva a ordem equilibrada na alma dos que nela crêem." (VOEGELIN, 2009, p. 132)

Em Lévi-Strauss, como expresso no Capítulo III, o intelecto humano, através do mito, "dá a ilusão ao homem de que ele pode entender o universo e de que ele entende, de facto, o universo. Como é evidente trata-se apenas de uma ilusão" (LÉVI-STRAUSS, 1985: 32). Não é possível, através do mito, conhecer o mundo, mas apenas “mediá-lo". Como disse o antropólogo:

"Em outras palavras, no momento em que todo o Universo, de um só golpe, tornou-se mais significativo, não tornou-se por isso mais bem conhecido, mesmo se for verdade que o aparecimento da linguagem devia precipitar o ritmo do desenvolvimento do conhecimento" (LÉVI-STRAUSS in MAUSS, 1974, p. 33)

Ou seja, no momento em que o homem através de sua simbolização mítica significou o Universo, para Lévi-Strauss, isso não quer dizer que ele passou a ser mais conhecido. Já para Voegelin, poderíamos dizer, que no momento em que o homem passou a significar o Universo, ele o representou de forma compacta na forma de mito, e esse mito possui a sua verdade, já que ele simboliza uma verdade: a estrutura quaternária da realidade. Seja mito, filosofia, ciência, poesia, para Voegelin o que mantém a equivalência dessas simbolizações é fato de que o homem sempre experiencia a mesma substância da história: a "comunidade primordial do ser", ou a realidade e sua estrutura quaternária.

\section{$* *$}

$\mathrm{Na}$ introdução expus as perguntas que guiariam esse trabalho: a ordem é produzida de forma arbitrária ou ela é fruto de uma lógica? Se a ordem é arbitrária, como podemos explicar esse fenômeno da universalidade de algumas características da cultura? Se a ordem é fruto de alguma lógica, de onde provém essa lógica? 
Para Voegelin, a ordem é fruto sim de uma lógica e essa pode ser encontra na própria experiência humana da metaxy, em que o homem pode entrar em contato com a fonte de toda a ordem, que se encontra na transcendência. No fundo, a ideia de Voegelin é a aquela mesma que Berger anuncia como possibilidade:

“[...] o homem projeta significados últimos na realidade porque a realidade tem, de fato, um significado último, e porque seu próprio ser (base empírica dessas projeções) contém e pretende esses significados últimos. Um tal procedimento teológico, caso seja exequiível, seria uma brincadeira interessante com Feuerbach: a redução da teologia à antropologia acabaria na reconstrução da antropologia em uma forma teológica. Lamentavelmente, não estou em posição de oferecer tal proeza aqui, mas que, pelo menos, sugerir essa possibilidade ao teólogo." (BERGER, 2012, p. 187)

Em Voegelin, o ser pretende os significados últimos e passa a contê-los, pelos menos em parte, quando através da metaxy passa a tomar consciência das verdades da realidade através da fonte da ordem: Deus. Há, assim, uma ordem que não é fabricada pelo homem e por meio da qual o homem precisa se sintonizar para produzir a ordem correta na sua alma e na sociedade:

"Ordem é a estrutura da realidade como experienciada pelo homem, bem como a sintonia entre o homem e uma ordem não fabricada por ele, isto é, a ordem cósmica" (VOEGELIN, 2008, p. 117).

"Renunciar ao plano divino e voltar-se para ele tornam-se as categorias fundamentais para descrever os estados de ordem e desordem na existência humana" (VOEGELIN, 2008, p. 148)

Mas, enquanto Berger apresenta uma possibilidade de se admitir de que o universo possa ter um significado último e que o homem possa acessá-lo, Voegelin trabalha toda a sua Ordem e História em cima dessa possibilidade, que para é um fato, e oferece essa teoria não só ao teólogo, como parece ser o caso de Berger, mas a todos os campos do conhecimento, incluindo as Ciências Sociais.

Para Lévi-Strauss, a ordem é uma mistura entre arbitrariedade e lógica. Como expliquei no Capítulo III, o pensamento humano se estrutura através de uma e mesma lógica: o binarismo. Mas, como, pra ele, não existe categorias $a$ priori, a escolha dos elementos que irão compor os seus sistemas lógicos, como é o caso do mito, é feita de maneira arbitrária (mesmo que se respeite uma “gramática das coisas"). Apesar, de que da organização da ordem, como a que é 
feita através do mito, fazerem parte estruturas de cognição que já pré-moldam a maneira como se organizará os elementos numa lógica, como é o caso do binarismo, não há em Lévi-Strauss uma ordem ou um fundamento das ordens a que os homens possam se sintonizar para ordenarem seu mundo social. A estrutura do mito é da ordem da estrutura do pensamento: ele tenta dar conta do binarismo, mas sem resolvê-lo, apenas mediando-o para que o sistema social não imploda.

Se há uma temática constante na narrativa mítica, segundo Lévi-Strauss, é a passagem da natureza para cultura quando foi rompida a relação entre mundo celeste e o mundo terrestre. A resposta dada pelo mito não aumenta o conhecimento humano sobre as coisas, como a passagem citada acima do antropólogo. No fundo, Lévi-Strauss, como vimos, também fecha a relação entre o mundo terrestre e o mundo celeste. É impressionante observar a passagem em que ele explica o que é o mito:

“[...] Se você interrogar um índio americano, seriam muitas as chances de que a resposta fosse esta: uma história do tempo em que os homens e os animais ainda não eram diferentes. Porque, apesar das nuvens de tinta projetadas pela tradição judaico-cristã para mascará-la, nenhuma situação parece mais trágica, mais ofensiva ao coração e ao espírito do que a situação de uma humanidade que coexiste com outras espécies vivias sobre uma terra cuja posse partilham, e com as quais não pode comunicar-se. Compreendemos que os mitos se recusem a tomar esse defeito da criação como original; que vejam em sua aparição o acontecimento inaugural da condição humana e da sua fraqueza." (ERIBON, 2005, p. 196)

É verdade que todos os mitos que tratamos aqui, o mito de Adapa, de Adão, da raia e de Édipo, possuem a característica de se passarem em uma "época primordial" em que humanos e não-humanos podiam se comunicar. Mas, enquanto Voegelin via na impossibilidade que se criou dessa comunicação uma "queda espiritual na condição do ser", Lévi-Strauss observa que essa "nova" situação é a situação mais trágica, mais ofensiva ao coração e ao espírito humano.

Me parece, assim, que Lévi-Strauss, não escapamento ao seu método, vê nessa situação a mais trágica realidade da condição humana, uma situação que se encontra somente na imanência. Ao passo que Voegelin, também não escapamento ao seu olhar "metafísico", vê o homem como sedento pela ordem que se encontra na divindade e aquilo que ofende o homem, nessa perspectiva, não é poder ou não se comunicar com outras espécies vivas, mas estar 
impossibilidade de compreender a totalidade que o rodeio por causa da sua "queda" da condição inicial.

Ao fim, me parece que Lévi-Strauss não pretendeu dar uma resposta última sobre a arbitrariedade ou não da ordem. Enquanto ele postula uma regra universal de organização da ordem, a proibição do incesto (em As estruturas elementares do parentesco), que para ele nada tem de arbitrária, pois "tais esquemas são espécies de imperativos categóricos inscritos na arquitetura do espírito - a exigência de regras, a noção de reciprocidade e o caráter sintético do dom" (DESCOLA, 2011, p. 48); é difícil retirar da estrutura dos mitos outras regras que estruturem universalmente a ordem, apesar de tratarem do recorrente tema da passagem da natureza para a cultura. $\mathrm{O}$ que está inscrito na realidade é a natureza que apreende os elementos da realidade de forma binária. E, como, para Lévi-Strauss, o pensamento é da mesma ordem que a natureza, a natureza e o pensamento se estruturam em "estruturas de contradição", que, como presente no Capítulo III, já é um princípio de ordem, o da não-contradição. Mas, diz o antropólogo: "Em tudo o que escrevi sobre mitologia, quis mostrar que nunca se chega a um sentido final. Isso acontece alguma vez na vida?” (ERIBON, 2005, p. 120)

Voegelin e Lévi-Strauss foram dois espíritos que dificilmente podemos encontrar no meio científico. Dedicaram-se todo o tempo a aprimorar seus pensamentos, suas teorias, sem jamais se distanciarem da "honestidade intelectual", tão faltante no ambiente intelectual dos dias de hoje.

Suas análises sobre a ordem, o significado e a simbolização, em tempos de desordem quase total como os dias atuais, onde o significado das coisas parece se esvair para recônditos lugares, são água fresca no deserto. Pensar sobre a ordem, hoje, não é uma curiosidade mas uma imposição do Zeitgeist.

Essa dissertação se propôs a ser uma pequena contribuição sobre a temática da ordem nos autores apresentados. Após absorver todo esse conhecimento, digo que há ainda muito o que se fazer, pessoalmente e na própria história da nossa disciplina, para que se possa compreender as perguntas essenciais que postulei na introdução. E digo, juntamente com Mauss, que ainda 
descobriremos "[...] que existem muitas luas mortas, ou pálidas, ou obscuras no firmamento da razão" (MAUSS, 1974, p. 45). 


\section{6. \\ Referências bibliográficas}

ARISTÓTELES. Metafísica. São Paulo: Ed. Loyola, 1987.

ALEXANDER, Jeffrey. "O novo movimento teórico", 1986. Texto apresentado no $X$ Encontro Anual da ANPOCS - Associação Nacional de Pesquisa e PósGraduação em Ciências Sociais, realizado em outubro de 1986, em Campos do Jordão, SP. Originalmente preparado para publicação em SMELSER, N. J. \& BURT, R. (eds.). Handbook of Sociology. Beverly Hills and London, Sage Publications, no prelo. Traduzido do inglês por Plínio Dentzien.

BERGER, Peter. O dossel sagrado: elementos para uma sociologia da religião. São Paulo: Paulus, 2012.

BERGER, Peter; LUCKMANN, Thomas. A construção social da realidade. Petrópolis: Editora Vozes, 2005.

CHAIMOVICH, Felipe Soeiro. "Lógica e racionalidade em Lévi-Strauss". In: Cadernos de Campos: revista dos alunos da Pós-graduação em Antropologia da Universidade de São Paulo. São Paulo: Edusp, 1992.

DESCOLA, Philippe. "As duas naturezas de Lévi-Strauss". In: Sociologia \& Antropologia. Vol. I, no 2. Rio de Janeiro: Editora da UFRJ, 2011. pp. 35-51.

DUARTE, Adriane da Silva (Ed.). O melhor do teatro grego: Prometeu acorrentado, Édipo Rei, Medéia e As nuvens. Rio de Janeiro: Zahar, 2013.

ELIADE, Mircea. Origens: história e sentido na religião. Lisboa: Edições 70, 1979.

O mito do eterno retorno. São Paulo: Cultrix, 1980.

. O sagrado e o profano. São Paulo: Martin Fontes, 1996.

ERIBON, Didier. De perto e de longe. São Paulo: Cosac Naify, 2005.

ERIKSEN, T. H.; NIELSEN, F.S. História da Antropologia. Petrópolis: Editora Vozes, 2007.

FRANKFORT, Henri. Kingship and the gods: A Study of Ancient Near Eastern Religion as the Integration of Society and Nature. Chicago: University of Chicago Press, 1950.

GORDON, Flávio. "A Cidade dos Brights: Religião, Ciência e Política no Movimento Neo-Ateísta". Tese de Doutorado. Rio de Janeiro, Universidade Federal do Rio de Janeiro, Museu Nacional, Programa de Pós-Graduação em 
Antropologia Social, 2011.

GUÉNON, René. Le symbolism de la croix. Paris: Végas, 1950.

HEIDEL, Alexander. The babylonian genesis: the story of creation. Chicago: University of Chicago Press, 1951.

GEERTZ, Clifford. A interpretação das culturas. Rio de Janeiro: Zahar, 1978.

GERTH, Hans; MILLS, Wright. Caráter e estrutura social. Rio de Janeiro: Civilização Brasileira, 1973.

LÉVI-STRAUSS, Claude. As estruturas elementares do parentesco. Petrópolis: Editora Vozes, 1982. . Mito e Significado. Lisboa: Edições 70, 1985.

Antropologia estrutural. São Paulo: Cosac Naify,

$2012 \mathrm{a}$.

O pensamento selvagem. São Paulo: Papirus Editora,

$2012 b$.

MAUSS, Marcel. Sociologia e Antropologia. São Paulo: Editora da USP, 1974.

MERQUIOR, José Guilherme. De Praga a Paris: uma crítica do estruturalismo e do pensamento pós-estruturalista. Rio de Janeiro: Nova Fronteira, 1991.

NISBET, Robert. The sociological tradition. Londres: Heinemann Educational Books, 1966.

. “Eric Voegelin's vision”. In: National Affairs, nº 31, 1983.

. The quest for community: a study in ethics of order and freedom. Washington: Intercollegiate Studies Institute, 2010.

VOEGELIN, Eric. The Ecumenic Age. Baton Rouge : Louisiana State University Press, 1974.

- A nova ciência da política. Brasília: Unb, 1979.

. "Equivalences of Experience and Symbolization in History". In: Published Essays, 1966-1985. Vol. 12 of The Collected Works of Eric Voegelin, ed. Ellis Sandoz. Baton Rouge: Louisiana State University Press. pp. 115-133, 2004a.

"Structures of Consciousness". In: The Drama of Humanity and other miscellaneous papers, 1939-1985. Vol. 33 of of The Collected Works of Eric Voegelin, ed. Ellis Sandoz. Baton Rouge: Louisiana State University Press. pp. 351-383, 2004b.

Reflexões Autobiográficas. São Paulo: É Realizações, 2008. . Israel e a Revelação. São Paulo: Edições Loyola, 2009.

Realizações, 2010.

WEBB, Eugene. Eric Voegelin: Philosopher of History. Washington: University 
of Washington Press, 1981.

WILCKEN, Patrick. Claude Lévi-Strauss: o poeta no laboratório. Rio de Janeiro: Objetiva, 2011. 